\author{
Universidade de São Paulo \\ Escola de Enfermagem de Ribeirão Preto \\ Programa de Doutoramento do Interunidades
}

\title{
RISCOS PSICOSSOCIAIS RELACIONADOS AO ESTRESSE NO TRABALHO DAS EQUIPES DE SAÚDE DA FAMÍLIA E ESTRATÉGIAS DE GERENCIAMENTO
}

Silvia Helena Henriques Camelo

Ribeirão Preto 2006 


\section{Universidade de São Paulo \\ Escola de Enfermagem de Ribeirão Preto \\ Programa de Doutoramento do Interunidades}

\section{RISCOS PSICOSSOCIAIS RELACIONADOS AO ESTRESSE NO TRABALHO DAS EQUIPES DE SAÚDE DA FAMÍLIA E ESTRATÉGIAS DE GERENCIAMENTO}

Trabalho apresentado à Escola de Enfermagem de Ribeirão Preto da Universidade de São Paulo, para obtenção do Título de Doutor, junto ao Programa de Doutoramento do Interunidades, inserido na linha de Pesquisa: Sociedade, Saúde e Enfermagem.

Aluna: Silvia Helena Henriques Camelo Orientadora: Emília Luigi Saporiti Angerami

\section{Ribeirão Preto}




\section{FICHA CATALOGRÁFICA}

\section{Camelo, Silvia Helena Henriques}

Riscos psicossociais relacionados ao estresse no trabalho das Equipes de Saúde da Família e estratégias de gerenciamento. Ribeirão Preto, 2006.

161p.il:30cm

Doutorado apresentado à Escola de Enfermagem de Ribeirão Preto da Universidade de São Paulo, junto ao Programa de Doutoramento do Interunidades.

Orientadora: Angerami, Emília Luigi Saporiti

1. Risco Ocupacional. 2.Equipe interdisciplinar de saúde 3. Saúde da Família. 4. Controle de riscos . 


\section{Universidade de São Paulo \\ Escola de Enfermagem de Ribeirão Preto \\ Programa de Doutoramento do Interunidades}

\section{RISCOS PSICOSSOCIAIS RELACIONADOS AO ESTRESSE NO TRABALHO DAS EQUIPES DE SAÚDE DA FAMÍLIA E ESTRATÉGIAS DE GERENCIAMENTO}

Trabalho apresentado à Escola de Enfermagem de Ribeirão Preto da Universidade de São Paulo, para obtenção do Título de Doutor, junto ao Programa de Doutoramento do Interunidades.

Banca Examinadora

Profa.Dra. Emília Luigi Saporiti Angerami - Orientadora

Docente titular do Programa de Pós-graduação do Interunidades da Escola de Enfermagem de Ribeirão Preto/USP.

Profa. Dra. Ana Macia Spanó Nakano

Docente da Escola de Enfermagem de Ribeirão Preto/USP- Departamento

Materno Infantil e Saúde Pública

Profa. Dra. Maria Helena Marziale

Docente da Escola de Enfermagem de Ribeirão Preto/USP- Departamento Enfermagem Geral e Especializada e do Programa do Interunidades.

Prof. Dra. Eliete Maria Silva

Docente da Universidade Estadual de Campinas/ Faculdade de Ciências Médicas.

Prof. Dra. Carmem Lúcia Cardoso

Docente da Faculdade de Filosofia, Ciências e Letras de Ribeirão Preto/USP-

Departamento de Psicologia e Educação. 


\section{Minha eterna gratidão:}

Aos meus pais José e Anézia, que me deram a vida, o amor e educação, sempre apoiando as minhas decisões.

Ao meu esposo José Simon por seu amor e companheirismo.

Aos meus filhos Gabriela e Guilherme que iluminam a minha vida. 


\section{Agradecimentos Especiais}

A Deus, pela proteção e iluminação, me concedendo força e coragem para seguir o meu caminho, enfrentando os obstáculos necessários para o meu crescimento.

À Profa. Dra. Emília L. S. Angerami, minha orientadora que, com suas orientações criteriosas, colaborou de maneira significativa na realização desse trabalho. Meu carinho e gratidão a você que soube transmitir seus conhecimentos apoiando-me nas minhas dificuldades.

À Profa. Dra. Ana Márcia S. Nakano, pela valiosa colaboração na metodologia do trabalho.

A Todos os trabalhadores das Equipes de Saúde da Família, participantes desse estudo, pela seriedade e senso de colaboração durante a realização desse trabalho.

Aos docentes e amigos do Centro Universitário Barão de Mauá, que direta ou indiretamente foram companheiros nesta jornada.

Às minhas amigas Lucieli Dias e Iselda pelo apoio e carinho nos momentos de dificuldades. 
CAMELO, S.H.H. Riscos psicossociais relacionados ao estresse no trabalho das Equipes de Saúde da Família e estratégias de gerenciamento, 2006, 161p. Tese (Doutorado) - Escola de Enfermagem de Ribeirão Preto, Ribeirão Preto, Universidade de São Paulo, 2006.

\section{RESUMO}

O Programa de Saúde da Família é uma das estratégias assumidas pelo Ministério da Saúde com vista à reorganização da atenção básica à saúde. Para a execução desta prática de assistência, é necessária a estruturação de equipes multiprofissionais que correspondam às necessidades da população. Os profissionais destas equipes assumem múltiplas tarefas com alto grau de exigência e responsabilidades, e desenvolver este tipo de atividade junto à comunidade, onde a realidade do indivíduo fica muito próxima, os problemas são de diversas ordens, as limitações internas e externas incontáveis, expõem o trabalhador a riscos físicos e/ou psicossociais tornando-os pessoas vulneráveis ao estresse. Esta investigação objetivou identificar e analisar os riscos psicossociais no trabalho das Equipes de Saúde da Família do município de Ribeirão Preto e descrever as estratégias utilizadas pelos trabalhadores para amenizar os efeitos desgastantes destes riscos. Este estudo do tipo exploratório utilizou-se da abordagem qualitativa, modalidade temática. Participaram do estudo, 24 trabalhadores, dentre eles, médicos, enfermeiros, auxiliares de enfermagem e agentes comunitários de saúde. Os dados foram coletados por meio de entrevistas semiestruturadas e a análise do material foi executada através do agrupamento e classificação das unidades temáticas em dois temas centrais, que são os "riscos psicossociais relacionados ao trabalho" e as "estratégias para o controle dos riscos psicossociais". Os riscos psicossociais encontrados foram: falta de preparo e capacitação, sobrecarga de papéis, longas horas de trabalho, conflito no trabalho em equipe, dificuldade para conciliar trabalho e família, recursos materiais e humanos insuficientes. As estratégias utilizadas para o controle destes riscos são predominantemente individuais, no entanto, o serviço tem uma reunião semanal programada com a equipe, para discussão dos problemas e sugestões, sendo considerada pelos trabalhadores um momento de alívio das tensões. No entendimento de que a realidade sanitária é dinâmica, emergem deste estudo sugestões que podem nortear a estruturação de novas Equipes de Saúde da Família: A qualificação para atuar neste campo é fundamental e deve ser iniciada nos programas de graduação e ter continuidade em serviço; a disponibilização de recursos humanos e materiais tornase imprescindível. Um serviço de apoio aos profissionais deve, entre outras atividades, orientá-los sobre os riscos a que estão expostos.

Descritores: 1. Risco ocupacional. 2. Equipe Interdisciplinar de Saúde. 3. Saúde da Família. 4. Controle de riscos. 
CAMELO, S.H.H. Risks psychosocial associated with work-related stress of the teams family health and strategies of the management, 2006, 161p. Thesis (Doctoral)Nursing School of Ribeirão Preto, University of São Paulo, Ribeirão Preto, 2006

\section{ABSTRACT}

The Program of Health Family is one of the strategies of the Health Office whose objective is the reorganization of the basic health attention. The execution of this new practice presumes the formation of professional teams that fulfil the necessity of the population. The professional of this teams carry out diverse functions with high degree of demand and responsibilities. The development of this activity besides the community, where the reality of individual is near, the problems are diverse and the limitations are present, expose the workers to the physical and psychosocial risks that can to cause stress. This investigation identified and analyzed the psychosocial risks in the work of health family teams of Ribeirão Preto city, and the control strategies utilized to alleviate fraying effects of those risks. This study had a character mainly exploratory. The participants in this study were 24 workers, among doctors, nurses, nursing auxiliary and health community agents. The analysis of the present study was based on the qualitative interpretation, thematic modality. It was employed a semi structured interview, and the analysis was performed through grouping and classification in two central themes, that are "the psychosocial risks related to the work " and "the strategy to the control of the psychosocial risks" . They were identified some psychosocial risks related to the job, such as: the workers are unprepared and had no skills enough, excess of bureaucracy, long journeys of work, conflicts inside of the work teams, difficulty to conciliate job and family, insufficiency of human and material resources. The strategies utilized to the relieve these risks are mainly individuals, however, the institution contribute organizing meetings weekly, to discuss problems and create suggests. It is necessary to better structure the teams of health family, using adequately qualified professionals, understanding that the sanitary reality is dynamic. The qualification on this area is fundamental, and may be initiated on the graduation programs and should continue into the service. It's necessary the availability of human and material resources. A support service to the health professionals should to direct them about the risks which they are exposed too.

Descriptores: 1.Occupational Risk. 2. Patiente Care team. 3. Health Family. 4. Risk Management 
CAMELO, S.H.H. Riesgos psicosociales relacionados al estrés en el trabajo de los Equipos de Salud de la Familia y estrategias de gerenciamiento, 2006, 161p. Tesis (Doctorado) - Escuela de Enfermería de Ribeirão Preto, Ribeirão Preto, Universidad de São Paulo, 2006.

\section{RESUMEN}

El Programa de Salud de la Familia es una de las estrategias asumidas por el Ministerio de Salud con la finalidad de reorganizar la atención básica a la salud. Para la ejecución de esta práctica de asistencia, es necesaria la estructuración de equipos multiprofesionales que respondan a las necesidades de la población. Los profesionales de estos equipos asumen múltiples tareas, con alto grado de exigencia y responsabilidad. Desarrollar este tipo de actividad en la comunidad, nos aproxima a la realidad de cada individuo, enfrentando problemas de diversas ordenes con limitaciones internas y externas incontables. Esta situación expone al trabajador a riesgos físicos y/o psicosociales tornándole una persona vulnerable al estrés. El objetivo de esta investigación fue identificar y analizar los riesgos psicosociales en el trabajo de los Equipos de Salud de la Familia del municipio de Ribeirão Preto y describir las estrategias utilizadas por los trabajadores para disminuir los efectos de estos riesgos. Este estudio exploratorio utilizó la técnica de análisis de contenido, modalidad temática. Participaron del estudio, 24 trabajadores, entre ellos, médicos, enfermeros, auxiliares de enfermería y agentes comunitarios de salud. Los datos fueron recolectados por medio de entrevistas semi-estructuradas y el análisis del material fue realizado a través del agrupamiento y clasificación de las unidades temáticas en dos temas centrales: "riesgos psicosociales relacionados al trabajo" y "estrategias para el control de los riesgos psicosociales". Los riesgos psicosociales encontrados fueron: falta de preparo y capacitación, exagerado número de responsabilidades, largas horas de trabajo, conflicto en el trabajo en equipo, dificultad para conciliar trabajo y familia, recursos materiales y humanos insuficientes. Las estrategias utilizadas para el control de estos riesgos son predominantemente individuales, entretanto el servicio tiene una reunión semanal programada con el equipo, para discusión de los problemas y sugerencias, siendo considerado por los trabajadores como un momento de alivio de las tensiones. Partiendo de la comprensión de que la realidad sanitaria es dinámica, surgen de este estudio sugerencias que pueden orientar una nueva estructuración de los Equipos de Salud de la Familia: La calificación para actuar en este campo es fundamental y debe ser iniciada en los programas de graduación y tener continuidad en servicios de salud; la disponibilidad de recursos humanos y materiales se torna imprescindible. Un servicio de apoyo a los profesionales debe, entre otras actividades, orientarlos sobre los riesgos al que están expuestos.

Descriptores: 1. Riesgo ocupacional. 2. Equipo Interdisciplinar de Salud. 3. Salud de la Familia. 4. Control de riesgos. 


\section{SUMÁRIO}

\section{Lista de Figuras}

Lista de Abreviaturas

Lista de Quadros

Resumo

Abstract

Resumen

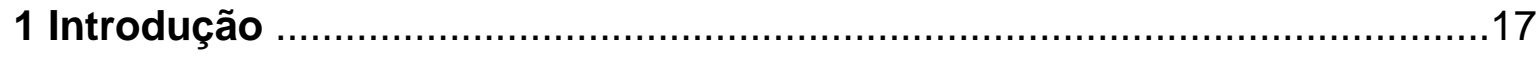

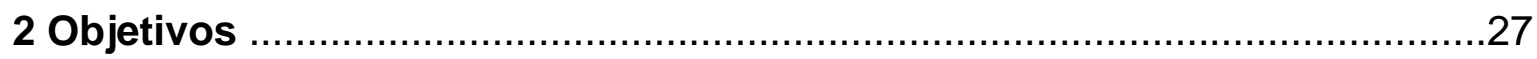

3 Referencial Teórico

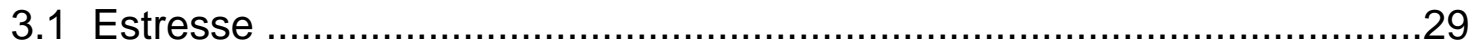

3.2 Eventos Geradores de Estresse : riscos psicossociais no trabalho que

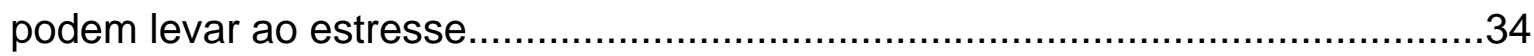

3.3 Controle e gerenciamento dos riscos inerentes ao estresse

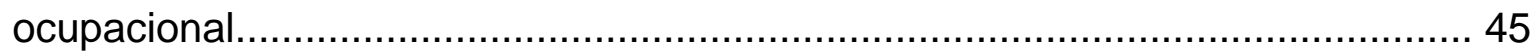

3.4 Modelo de Assistência de Saúde da Família...................................50

4 Material e Método

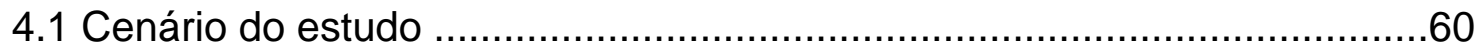

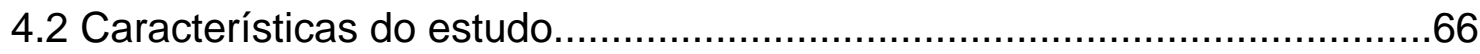

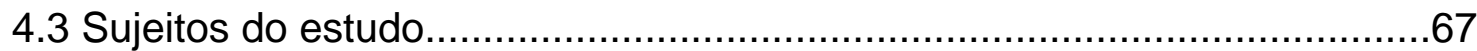

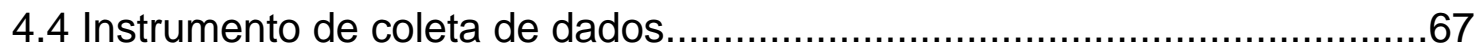

4.5 Procedimento de Coleta de dados..........................................68

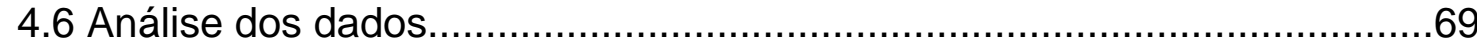

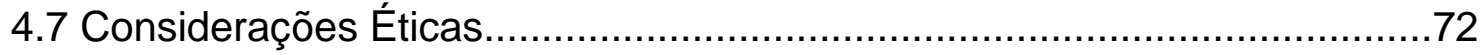

\section{Resultados}

5.1 O Programa de Saúde da Família e o cenário institucional da

Pesquisa 


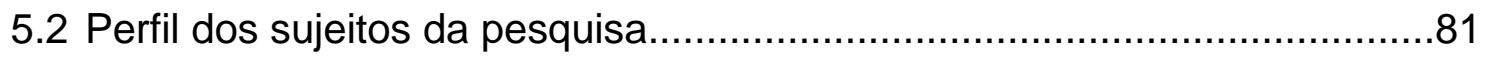

5.3 Riscos psicossociais relacionados ao trabalho das Equipes de Saúde da Família .83

5.4 Estratégias de controle dos riscos psicossociais. 121

6 Riscos psicossociais no trabalho das Equipes de Saúde da Família e estratégias de gerenciamento. 131

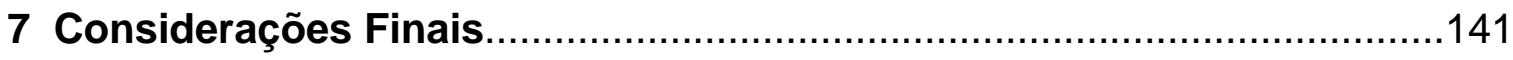

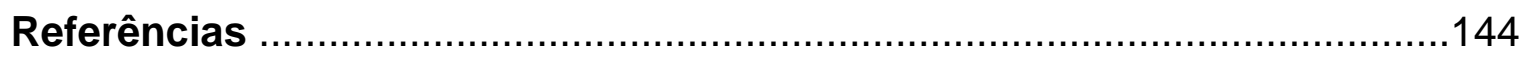

Anexo I Autorização do Comitê de Ética em Pesquisa.....................................157

Apêndice I Roteiro para a realização das entrevistas....................................159

Apêndice II Termo de Consentimento Livre e Esclarecido..............................160 


\section{LISTA DE FIGURAS}

Figura 1- Resposta ao estímulo estressor, segundo Selye, 1956.....................30

Figura 2- Organograma das Unidades Básicas de Saúde da Rede Municipal de

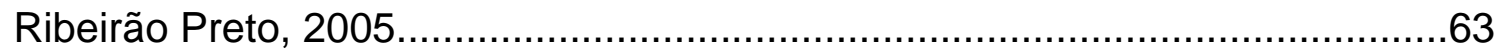




\section{LISTA DE ABREVIATURAS}

AIS Ações Integradas de Saúde

ACS Agente Comunitário de Saúde

CAPS Centro de Atenção Psicossocial

CIDS Centro de Informação Digital em Saúde do município de Ribeirão Preto

CINAEM Comissão Interinstitucional Nacional de Avaliação de Escolas Médicas

CODERP Companhia de Desenvolvimento Econômico de Ribeirão Preto

CNS Conferência Nacional de Saúde

DORT Distúrbios Osteomusculares Relacionados ao Trabalho

ESF Equipe de Saúde da Família

FAEPA Fundação de Apoio ao Ensino, Pesquisa e Assistência do Hospital das

Clínicas da Faculdade de Medicina de Ribeirão Preto da Universidade de São Paulo

LER Lesões por Esforços Repetitivos

MEC Ministério da Educação

MS Ministério da Saúde

NOB Norma Operacional Básica

NGA Núcleo de Gestão Assistencial

OIT Organização Internacional do Trabalho 
PROMED Programa de Incentivo às Mudanças Curriculares nos Cursos de

Medicina

PRO-SAUDE Programa Nacional de Reorientação da Formação Profissional em

Saúde

PITS Programa de Interiorização do Trabalho em Saúde

PSF $\quad$ Programa de Saúde da Família

RA Reação de Alarme

RE $\quad$ Fase de Exaustão

RR Fase de Resistência

SMS Secretaria Municipal de Saúde

SAL Síndrome de Adaptação Local

SAG Síndrome de Adaptação Geral

SUS Sistema Único de Saúde

UBDS Unidade Básica e Distrital de Saúde

USF $\quad$ Unidade de Saúde da Família 


\section{LISTA DE QUADROS}

Quadro 1. Riscos psicossociais relacionados ao trabalho que podem causar estresse

Quadro 2. Distribuição da previsão de recursos humanos de acordo com a área de abrangência das Unidades Básicas de Saúde. Ribeirão Preto, 2004.

Quadro 3. Distribuição de recursos humanos das Equipes de Saúde da Família por categoria profissional. Ribeirão Preto, 2005.

Quadro 4. Distribuição dos trabalhadores das Equipes de Saúde da Família segundo as suas Unidades Básicas de Saúde e categoria profissional. Ribeirão Preto,2005...81

Quadro 5. Distribuição dos trabalhadores pertencentes às Equipes de Saúde da Família, segundo sexo, idade e categoria profissional. Ribeirão Preto, 2005. .82

Quadro 6. Distribuição da Unidades Temáticas relacionadas aos riscos psicossociais no trabalho das Equipes de Saúde da Família, segundo a sua freqüência em cada categoria profissional, Ribeirão Preto, 2005.

Quadro 7. Distribuição das Unidades Temáticas relacionadas as estratégias de gerenciamento dos riscos psicossociais e sua freqüência nas falas de cada categoria profissional, Ribeirão Preto, 2005. 
1 INTRODUÇÃO 
Nas últimas décadas, a crise estrutural do setor público gera um hiato entre os direitos constitucionalmente garantidos e a efetiva capacidade de oferta dos serviços públicos associados aos mesmos, sendo percebida na fragilidade apresentada tanto na eficiência como na eficácia da gestão das políticas sociais e econômicas.

Como continuidade ao processo iniciado com as Ações Integradas de Saúde (AIS) - que tinham a meta de integrar os serviços públicos de saúdeocorreu o movimento denominado Reforma Sanitária. Este movimento, encetado pelo projeto contra-hegemônico nos campos político, ideológico e institucional, desde o início dos anos 70, vai confluir para a VIII Conferência Nacional de Saúde, em março de 1986. Esta conferência apresenta duas características principais: Uma, o seu caráter democrático, pela significativa presença de milhares de delegados representativos de quase todas as forças sociais interessadas na questão da saúde. Outra, refere-se a sua configuração como um processo social que começa com conferências municipais e estaduais, até chegar à nacional (MENDES, 1995).

A VIII Conferência Nacional da Saúde (CNS) constitui o momento apical de formatação político-ideológica do projeto da Reforma Sanitária Brasileira. À partir do resultado deste encontro, surgiram propostas de reformulação do Sistema Nacional de Saúde, sendo documentadas e conhecidas como Projeto da Reforma Sanitária.

De acordo com Paim (1992, 31), "o Projeto da Reforma Sanitária foi gerado na luta contra o autoritarismo e pela ampliação dos direitos sociais". Pode-se perceber que a população começa a lutar por seus direitos de cidadãos e pela melhoria da qualidade de vida. Isto também torna-se evidente pela ampliação do conceito de saúde, explicitado na VIII CNS na qual "Saúde é a resultante das condições de alimentação, habitação, educação, renda, meio ambiente, trabalho, transporte, emprego, lazer, liberdade, acesso e posse da terra e acesso a serviços de saúde"( BRASIL, 1996, 118).

A partir da Constituição Federal de 1988, foram contempladas as propostas oriundas da VIII Conferência Nacional de Saúde (CNS), a descentralização da gestão, integralidade das ações, fortalecimento do município, participação da comunidade, englobando então a proposta da Reforma Sanitária e do Sistema Único de Saúde (SUS). Para a implantação efetiva e legal do SUS, fez-se necessária a formulação de leis, e somente em 1990 foram aprovadas as Leis 
Orgânicas da Saúde - Leis 8080 e 8142 (MENDES, 1995). Estas leis destacam os princípios organizativos e operacionais do sistema, tais como a construção de um modelo de atenção fundamentado na epidemiologia, no controle social e um sistema descentralizado e regionalizado com base municipal.

Portanto o SUS traz como princípios norteadores: saúde como direito de todos e dever do Estado; universalidade e eqüidade do acesso; superação da dicotomia entre prevenção e cura; integralidade na assistência ao indivíduo; descentralização com gestor único em cada esfera de governo; participação complementar do sistema privado, com preferência para os filantrópicos e os sem fins lucrativos; ênfase nas áreas de saúde do trabalhador, vigilância epidemiológica e sanitária, alimentação e nutrição; participação comunitária efetiva; financiamento tripartite entre União, Estados e Municípios.

O desafio básico do SUS é atender às necessidades reais da população brasileira. Ele deve buscar equilíbrio entre interesses coletivos e individuais, entre os diferentes atores sociais de um sistema de atenção, entre a eqüidade e a eficiência e entre os controles e liberdades dos profissionais. Dentro destas idéias organizadoras, está a descentralização das ações e decisões sobre a organização e funcionamento, através dos sistemas locais de saúde.

A descentralização é a forma de levar o processo decisório ao âmbito local, atendendo melhor às necessidades da população, dentro do espaço institucional.

Em vista da necessidade do estabelecimento de mecanismos capazes de assegurar a continuidade dessas conquistas sociais, várias propostas de mudanças, inspiradas pela Reforma Sanitária Brasileira e pelos princípios do SUS, têm sido esboçadas, traduzidas, entre outras, nos projetos de criação dos distritos sanitários e sistemas locais de saúde.

Essas iniciativas apresentam avanços e retrocessos e seus resultados não foram ainda suficientes para transformar a prática sanitária brasileira e suas reais condições, de modo a garantir a melhoria da qualidade de vida e saúde dos cidadãos brasileiros.

Nessa perspectiva, surgem situações contraditórias para estados e municípios, relacionadas à descontinuidade do processo de descentralização e ao desenho de um novo modelo assistencial. 
Diante dessa realidade, o Ministério da Saúde, em 1994, determina em seu plano de "ações e metas prioritárias" as estratégias de Saúde da Família e Agentes Comunitários como caminhos possíveis no processo de reorganização da atenção básica à saúde (BRASIL, 1998).

O Programa de Saúde da Família (PSF) é uma das estratégias do Ministério da Saúde e tem o objetivo geral de "melhorar o estado de saúde da população mediante a construção de um modelo assistencial baseado na promoção, proteção, diagnóstico precoce, tratamento e recuperação da saúde", em conformidade com os princípios e diretrizes do SUS. No modelo em questão, a atenção está centrada na família entendida e percebida a partir do seu ambiente físico e social, o que possibilita às equipes de saúde ligadas a este modelo uma maior compreensão do processo saúde/doença e da necessidade de intervenção que vai além de práticas curativas (BRASIL, 1998).

Um desafio central do programa é mostrar sua capacidade de integração com os serviços locais de saúde, redefinindo qualitativamente seu modelo de atuação e mostrando que não é uma proposta de atenção simplificada e barata para áreas rurais e pobres do país. O PSF deve provar que, ao contrário de simplificação, é um alargamento da atenção básica à saúde em direção à incorporação de práticas preventivas, educativas e curativas mais próximas da vida cotidiana da população e, especialmente, dos seus grupos mais vulneráveis.

A estratégia desse modelo, portanto, deve ter os excluídos e as regiões mais pobres como prioridade e deve utilizar largamente tecnologias custo/efetivas, ter uma Equipe de Saúde da Família em território de abrangência definido, desenvolver ações focalizadas na saúde, dirigidas às famílias e ao seu hábitat, de forma contínua, personalizada e ativa, com ênfase relativa no promocional e no preventivo, mas sem descuidar do curativo-reabilitador, com alta resolutividade, com baixos custos diretos e indiretos, sejam econômicos, sociais e articulando-se com outros setores que determinam a saúde (MENDES,1996).

No Programa de Saúde da Família, a Equipe de Saúde da Família é a unidade produtora dos serviços de saúde, em que cada profissional executa um dado conjunto de ações, em separado, porém buscando, constante e continuamente, articulá-las às ações realizadas pelos demais agentes.

As Equipes de Saúde da Família devem, na realização de suas atividades, avaliar os indicadores de saúde de sua área; conhecer a realidade das 
famílias pelas quais são responsáveis, com ênfase nas suas características sociais, demográficas e epidemiológicas; identificar os problemas de saúde mais comuns e situações de risco aos quais a população está exposta; elaborar com a participação da comunidade um plano local para o enfrentamento dos fatores que colocam em risco a saúde; programar as atividades e reestruturar o processo de trabalho; prestar assistência integral; utilizar os sistemas de referência e contra-referência de forma contínua e racionalizada para resolver os principais problemas detectados; desenvolver processos educativos para a saúde e promover ações intersetoriais para o enfrentamento dos problemas identificados; realizar as atividades de visita domiciliar e internação domiciliar e participar de grupos comunitários; valorizar a relação com o usuário e com a família para criação de vínculo de confiança; promover a qualidade de vida e contribuir para que o meio ambiente torne-se mais saudável além de muitas outras atividades ( BRASIL, 1998).

Esse modelo de atenção à saúde, conforme proposto, nos leva à reflexão sobre a necessidade de equipes de saúde com perfis profissionais que correspondam às demandas identificadas na população, com uma atuação que leve em conta as dimensões sociais, econômicas, subjetivas e biológicas dos usuários (CORNETA et al.,1996).

O profissional da Equipe de Saúde da Família precisa ser capaz de atuar com criatividade e senso crítico, mediante uma prática humanizada, competente e resolutiva. Ele deve buscar uma prática para desenvolver habilidades visando ao atendimento e à promoção da saúde da comunidade a que pertence; a compreensão disto é que o colocará em posição de dizer que é um profissional de saúde da família e que a sua unidade tem uma prática diferenciada (WAGNER, 1996).

Para a formação da Equipe de Saúde da Família (ESF), recomenda-se uma equipe multiprofissional composta minimamente por um médico, um enfermeiro, um auxiliar de enfermagem, quatro a seis agentes comunitários de saúde e uma equipe de saúde bucal. Outros profissionais de saúde tais como, psicólogos, fisioterapeutas, podem ser incorporados a esta equipe básica, de acordo com as demandas e características da organização dos serviços de saúde locais.

O trabalho em equipe não deve ser o simples compartilhar do mesmo espaço físico em unidades de saúde, mas sim, deve haver uma real abordagem de inter ou transdisciplinaridade. Por esta razão, para que se exerça uma nova prática, 
são necessárias ações voltadas ao redirecionamento da participação dos profissionais de saúde, com vistas à construção da equipe de saúde como a verdadeira unidade produtora desses serviços. A especificidade das responsabilidades de cada membro jamais deverá ofuscar a missão comum da equipe, e sua prática democrática e construtiva precisa estar direcionada a uma maior motivação e eficiência de seu trabalho (BRASIL, 1998).

Para alcançar o objetivo de suas ações, a Equipe de Saúde da Família necessita conhecer a realidade da população sob sua responsabilidade: os contextos familiares e a vida comunitária, desenvolvendo um processo de planejamento pactuado em cada uma de suas fases: na programação, na execução e na avaliação (BRASIL, 1998).

Observa-se que são delegadas aos profissionais do Programa de Saúde da Família, múltiplas tarefas, com um alto grau de exigências e responsabilidades, para as quais, dependendo do ambiente e da organização do trabalho para a sua realização, e de seu preparo para exercer o papel, podem levar o profissional a enfrentar um desequilíbrio biológico que afeta não só a ele como pessoa, mas também à comunidade assistida. Este desequilíbrio biológico, com componentes físicos e psicológicos, que é conhecido como estresse, manifesta-se principalmente em forma de absenteísmo, alcoolismo, problemas emocionais, mudanças inexplicáveis na eficiência, desempenho irregular, impaciência com a população com quem lida e outros sérios problemas (LIPP, 1996).

Apesar das diferenças individuais, que não podem ser ignoradas, há evidência científica sugerindo determinadas situações estressantes no trabalho para a maioria dos trabalhadores. Estas situações são consideradas estressantes quando são percebidas como envolvendo uma grande exigência no trabalho o qual não é proporcional ao conhecimento e habilidades dos trabalhadores, ou por não estarem relacionadas às suas necessidades, especialmente quando os mesmos detêm pouco controle sobre o próprio trabalho (EUROPEAN AGENCY, 2000).

O estresse relacionado ao trabalho pode ser definido como um padrão de reações emocionais, cognitivas e comportamentais para aspectos diversos e difíceis do conteúdo do trabalho, organização e ambiente de trabalho. Este estado pode ser caracterizado por altos níveis de agitação e freqüentemente sentimentos de fuga (DIAMANTOPOULON, 2002). 
Todos os trabalhadores podem estar expostos a situações estressantes, mas algumas profissões necessitam de atenção constante, como é o caso dos profissionais de saúde, cuja ocupação exige das pessoas um estado de alerta máximo, por estarem em contato direto com o sofrimento, a dor e a morte, num ambiente de grande tensão emocional (RAPHAEL, 1999). Diante disso, os profissionais da saúde formam um grupo vulnerável ao processo de estresse.

Alguns autores se referem a riscos do ambiente de trabalho que podem causar estresse, dividindo-os em riscos físicos e psicossociais. A exposição a riscos físicos do trabalho pode estar ser associada à ansiedade que, por sua vez, conduz à experiência de estresse. Os riscos psicossociais relacionam-se a aspectos de planejamento, organização e gerenciamento do trabalho, e ao seu contexto ambiental e social, os quais apresentam potencial para causar prejuízo físico, social e psicológico podendo provocar estresse (COX; GRIFFTHS, 1995).

A experiência profissional na organização de Equipes de Saúde da Família nos mostrou que desenvolver este tipo de atividade junto à comunidade, onde a realidade do indivíduo fica muito próxima, os problemas são de diversas ordens, as limitações internas e externas incontáveis, expõem o trabalhador a riscos físicos e/ou psicossociais que podem desencadear o processo de estresse.

Partindo desses pressupostos, desenvolvemos uma pesquisa (CAMELO; ANGERAMI 2004) com equipes de profissionais de Unidades de Saúde da Família, para identificar sintomas de estresse nestes trabalhadores. O referido estudo foi realizado com uma amostra composta por 37 trabalhadores de equipes de cinco núcleos de saúde da família, onde pudemos observar, através de um instrumento de avaliação (LIPP, 1984), que 62\% dos profissionais apresentavam estresse, e destes $83 \%$ se encontravam na fase de resistência ${ }^{1}$ ou $2^{\text {a }}$ fase do processo de estresse.

A avaliação realizada revelou a presença de sintomas físicos e psicológicos das três fases do processo de estresse. Os sintomas físicos mais apontados pelos sujeitos desse estudo foram: tensão muscular, sensação de desgaste físico constante e insônia. Os sintomas psicológicos mais incidentes foram: vontade de iniciar novos projetos, pensar e falar constantemente em um

\footnotetext{
${ }^{1}$ A “Fase de Resistência” é descrita por Selye (1956), como havendo o incío dos sintomas da esfera psicossocial como : ansiedade, medo, isolamento social e outros.
} 
assunto, angústia/ansiedade diária e vontade de fugir de tudo (CAMELO; ANGERAMI, 2004).

Portanto, os trabalhadores das Equipes de Saúde da Família demonstraram possuir em sua maioria uma elevada soma de sintomas de estresse com maior ocorrência na área psicológica, $48 \%$ dos casos, seguidos da área física com $39 \%$ e $13 \%$ dos trabalhadores estressados demonstraram igualdade de sintomas, estando os resultados concentrados com maior freqüência na fase de resistência ou $2^{a}$ fase do processo de estresse (CAMELO; ANGERAMI, 2004).

O estresse é, portanto, uma realidade que pode estar presente na vida profissional destes trabalhadores e identificar suas causas torna-se fundamental para melhorar as condições de trabalho, prevenir doenças e conseqüentemente proporcionar uma assistência adequada à população.

De acordo com o Guia da Comissão Européia (2000), há necessidade de se identificarem as causas de estresse relacionadas ao trabalho. Segundo este guia, existem vários motivos para isto: o estresse constitui um problema para os trabalhadores, para a organização onde trabalham e para a sociedade; os problemas de estresse no trabalho estão aumentando e a maioria das causas podem ser evitável, se todos agirem conjuntamente visando a interesses próprios e mútuos.

Dessa forma, nas situações de trabalho, para prevenir o estresse, é necessário identificar os riscos no ambiente ao qual está associado. Para isto é preciso monitorar as condições do trabalho, os termos contratuais, as relações sociais no trabalho, a saúde, o bem-estar e a produtividade (EUROPEAN COMISSION, 2000).

Podemos pensar em algumas maneiras de gerenciar o estresse no trabalho, e as organizações têm proposto três objetivos para tal (COX; HOWARTH, 1990):

-Prevenção e controle freqüente da exposição aos riscos, através do planejamento e treinamento do trabalhador para enfrentar o estresse;

-Reação imediata: baseada no gerenciamento e em grupos de resolução de problemas, para melhorar as habilidades das organizações em reconhecer e negociar com o crescimento dos próprios problemas e a

-Reabilitação que consiste no oferecimento de suporte aos trabalhadores para auxiliar no enfrentamento de situações problemáticas. 
As estratégias de gerenciamento do estresse, quando implantadas em grupos, instituições, devem ter o intuito de conhecer as percepções e as necessidades das pessoas, grupos e instituições.

Um das formas conhecidas para aliviar o estresse no trabalho é a mudança organizacional permitindo, por exemplo, adequado tempo para o trabalhador realizar a sua tarefa, providenciando clara descrição de seu trabalho, permitindo autoridade do trabalhador, promovendo tolerância e justiça no local de trabalho, eliminando exposições físicas prejudiciais no ambiente, identificando fracassos, sucessos, causas e conseqüências deles e, finalmente, melhorando o ambiente ocupacional e a saúde (EUROPEAN COMISSION, 2000).

Corroborando com o descrito acima, verifica-se que para qualquer mudança no ambiente, na organização ou planejamento do trabalho, torna-se imprescindível partir do diagnóstico da realidade para direcionamento das intervenções de forma acertada.

O Programa de Saúde da Família é uma estratégia do Ministério da Saúde, no qual observamos que a organização, planejamento e gerenciamento dos serviços estão em construção, e o preparo dos profissionais que nele atuam constitui-se em uma de suas prioridades.

Considerando ser um trabalho essencialmente em equipe, que exige um estreito relacionamento, seus membros necessitam de conhecimentos e habilidades específicas.

Para assistir a comunidade extra-muros, é exigido dos trabalhadores criatividade e suporte técnico-científico adequados. Ao receber o cliente, nem sempre existe um ambiente de trabalho e recursos humanos compatíveis para o desempenho de uma prática humanizada, competente e resolutiva.

Estas ponderações, relacionadas a aspectos de organização, planejamento e gerenciamento do trabalho das Equipes de Saúde da Família, e os sintomas de estresse identificado nestes trabalhadores, pressupõem a exposição a riscos psicossociais que podem levar ao estresse, e julgamos oportuno direcionar nossa pesquisa para estes aspectos.

Nesta investigação nos propomos a identificar e analisar os riscos psicossociais existentes no trabalho das Equipes de Saúde da Família que podem gerar estresse, e as estratégias utilizadas para amenizar seus efeitos desgastantes. 
2 OBJETIVOS 
- Identificar e analisar os riscos psicossociais presentes no trabalho das Equipes de Saúde da Família do município de Ribeirão Preto.

- Descrever as estratégias utilizadas pelos trabalhadores das Equipes de Saúde da Família, para amenizar os efeitos desgastantes dos riscos psicossociais existentes. 
3 REFERENCIAL TEÓRICO 


\subsection{Estresse}

A palavra "stress" foi primeiramente utilizada na física, indicando o desgaste sofrido por materiais expostos a pressões ou forças ( LIMA; CARVALHO, 2000). Derivada do latim, a palavra "stress" foi utilizada pela primeira vez no sentido psicológico no século XVIII (SPILBERGER, 1979). Porém, foi inicialmente usada na área da saúde por Hans Selye, na época, estudante de medicina, em 1926, ao perceber que muitas pessoas sofriam de várias doenças físicas e apresentavam algumas queixas em comum como fadiga, pressão alta, desânimo e falta de apetite.

Selye introduziu o termo "stress" para designar uma síndrome produzida por vários agentes nocivos. Ele enfatiza a resposta não específica do organismo a situações que não o debilitam, enfraquecendo e levando o organismo a adoecer. Assim Selye (1956, p.17) define estresse como "o resultado inespecífico de qualquer demanda sobre o corpo, seja de efeito mental ou somático, e que estressor é todo agente ou demanda que evoca reação de estresse, seja de natureza física, mental ou emocional", sendo esta última um dos mais freqüentes ativadores.

Em seus estudos, Selye (1956) constatou que o estresse produzia alterações importantes, com extrapolação dos parâmetros normais na estrutura e composição química do corpo, que poderiam ser avaliadas. Essas manifestações eram reações de defesa e de adaptação frente ao agente estressor, na tentativa de manter o equilíbrio do organismo. A partir destas observações, ele descreveu a Síndrome de Adaptação Geral (SAG) que pode ser entendida como "o conjunto de todas as reações gerais do organismo que acompanham a exposição prolongada do estressor" (Selye, 1956, p.25). As alterações funcionais, bioquímicas e morfológicas que determinam e caracterizam a SAG são sempre as mesmas, qualquer que seja a natureza da causa que a provoca.

De acordo com Selye (1956), tal Síndrome apresenta três fases ou estágios ( Figura 1):

$1^{\text {a }}$ - FASE DE ALARME: O organismo tem uma excitação de agressão ou de fuga ao estressor, que podem ser entendidas como comportamento de adaptação. Esta fase inicia-se quando a pessoa se confronta inicialmente com um estressor. A principal ação do estresse é justamente a quebra do equilíbrio interno 
que ocorre em decorrência da ação exacerbada do sistema nervoso simpático e da desaceleração do sistema nervoso parassimpático em momentos de tensão. Esta fase é caracterizada por alguns sintomas como: taquicardia, tensão crônica, dor de cabeça, sensação de esgotamento, hipocloremia, pressão no peito, extremidades frias, dentre outros.

2ª - FASE DE RESISTÊNCIA: Havendo persistência da fase de alerta, o organismo altera seus parâmetros de normalidade e concentra a reação interna em um determinado órgão-alvo, desencadeando a SAL- Síndrome de Adaptação Local. Nesta fase há o desaparecimento da maioria dos sintomas físicos e há manifestação de sintomas da esfera psicossocial como: ansiedade, medo, isolamento social, roer unhas, oscilação do apetite, impotência sexual e outros. A persistência desta fase desencadeia uma situação chamada de "DISTRESS" ou "MAU STRESS", pois as estratégias de adaptação adotadas são agressivas para o próprio organismo.

$3^{a}$ - FASE DE EXAUSTÃO: O organismo encontra-se extenuado pelo excesso de atividades e pelo alto consumo de energia e ocorre a falência do órgão mobilizado na Síndrome de Adaptação Local, iniciada na fase de resistência, que se manifesta através de doenças orgânicas. Os sintomas dependem do comprometimento do órgão afetado e da evolução da doença, podendo até mesmo ocorrer a morte súbita.

A seguir temos uma ilustração gráfica do processo utilizando-se a resistência geral à lesão como indicador.

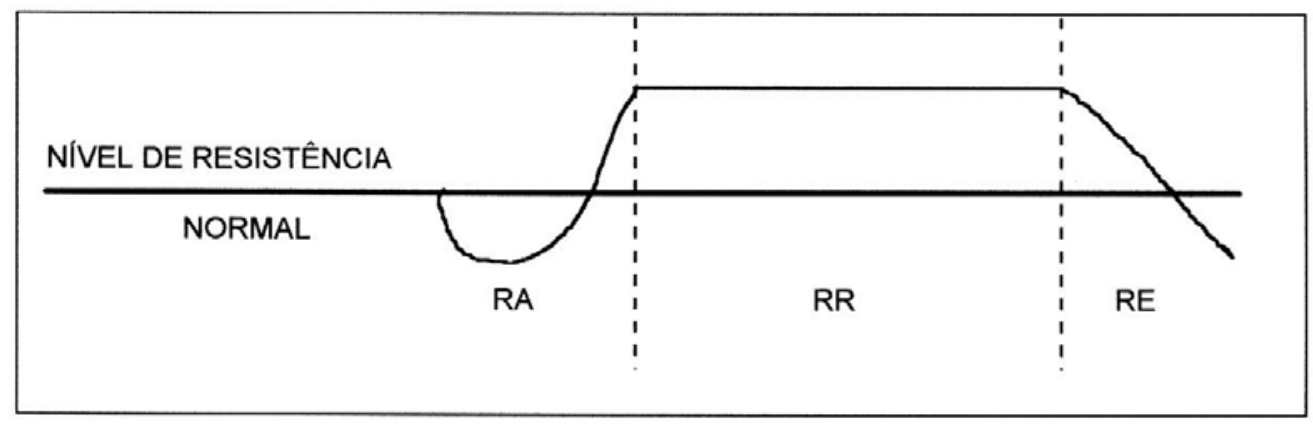

Figura 1- Resposta ao estímulo estressor

Fonte: SELYE, H. The stress of life. New York: Mc Graw Hill, 1956. 324p.

Na fase aguda da reação de alarme (RA), a resistência geral ao agente particular de estresse, que provocou a SAG, cai muito abaixo do normal. Então à 
medida que a adaptação se processa, na fase de resistência (RR), a capacidade de resistir ascende muito além do normal. Mas, eventualmente, na fase de exaustão (RE) a resistência cai novamente abaixo do normal (SELYE,1956).

Ainda que as respostas às situações tenham características individuais, o estresse coloca-se sempre como um desafio e como um fator de risco à saúde.

A partir dos estudos iniciais, perceberam-se a evolução e o acréscimo de novos conceitos, que contribuíram para uma análise mais abrangente sobre o assunto.

Para Molina (1996), "o estresse pode ser definido como qualquer tensão aguda ou crônica que produz uma mudança no comportamento físico e no estado emocional do indivíduo e uma resposta de adaptação psicofisiológica que pode ser negativa ou positiva no organismo. Lima (1994) comenta que o estresse ocorre quando a capacidade de adaptação do indivíduo é suplantada por eventos e sobrecargas emocionais muitas vezes no aspecto qualitativo, sendo quantitativamente insignificante e, na maioria das vezes decorre de excessos e tensões emocionais no âmbito afetivo, familiar, profissional e/ou social, sendo que as respostas e sintomatologia dependem da personalidade de cada indivíduo.

Como bem salienta Vasconcellos (1992), apesar de o termo estar integrado no nosso vocabulário, temos que atentar para a definição do mesmo. Assim, sugere a expressão "stress" para identificar o processo psicofisiológico em que o organismo se encontra e "reação de stress" para definir o comportamento que o organismo manifesta, decorrente do processo desenvolvido.

O estresse, portanto, surge como uma resposta a uma ativação máxima do organismo até que estratégias de enfrentamento, ou de adaptação atenuem o seu efeito (COSTA, 1997).

O indivíduo, ao se deparar com situações ameaçadoras e de grande exigência, pode passar por sensações de medo, de tristeza e de solidão, ou seja, vivencia sentimentos carregados de alterações comportamentais e orgânicas. Essas sensações, denominadas de emoções, desencadeiam alterações fisiológicas, através da estimulação nervosa e interferem diretamente na saúde do indivíduo.

Estudiosos afirmam que em algumas etapas da resposta orgânica ao estresse pode haver influência do nosso aparelho psíquico como mediador da reação de estresse que será desencadeada. Esses autores afirmam que há diferenças entre indivíduos e os grupos na sensibilidade e vulnerabilidade a certos 
tipos de eventos, bem como nas suas interpretações e reações ( LAZARUS; FOLKMAN,1984).

\subsubsection{Estresse relacionado ao trabalho}

O estresse tem sido considerado como um dos problemas que mais freqüentemente age sobre o ser humano, interferindo na homeostase de seu organismo devido à grande quantidade de tensões que enfrenta diariamente.

Pesquisadores definem o estresse como "uma relação particular entre a pessoa e o ambiente que é avaliado pela pessoa como desgastante ou superior aos seus recursos de enfrentamento e ameaçador a seu bem-estar" (LAZARUS; FOLKMAN, 1984, p150).

O estresse relacionado ao trabalho resulta de várias situações em que a pessoa percebe este ambiente como ameaçador às suas necessidades de realização pessoal e profissional, prejudicando sua interação com suas funções e com o ambiente de trabalho, na medida em que este ambiente contém demandas excessivas a ela, ou que ela não contenha recursos adequados para enfrentar tais situações (FRANÇA; RODRIGUES, 1999).

Assim, quando temos um organismo sob situação de estresse, resultamse distúrbios emocionais, mudanças de comportamento, distúrbios gastroinstestinais, distúrbios de sono, sintomas psicopatológicos, com sofrimento psíquico e outros.

O impacto do estresse no trabalho também pode ser sentido pela organização através de altos níveis de absenteísmo e rotatividade, falta de inovação e pouca produtividade por parte dos trabalhadores.

Algumas pessoas têm experimentado o estresse quando há um desequilíbrio entre as exigências do trabalho e os recursos ambientais e pessoais para lidar com elas. Esta relação entre demandas e recursos pode ser fortemente moderada por fatores como suporte social (dentro e fora do trabalho) e controle do trabalho (COX; RIAL-GONZÁLEZ, 2002).

Sérios problemas com estresse relacionado ao trabalho são geralmente causados por falta de conhecimento dentro da organização sobre como organizar o trabalho para ser eficiente e livre de estresse, porque o estresse é o oposto da 
eficiência. A longo prazo ele reduzirá o senso de perspectiva dos empregados e a habilidade deles para resolver problemas. Isto levará a um alto risco de doenças e absenteísmo devido à doença (FREDERICKSEN, 2002).

Quando o episódio estressante é de longa duração, as consequências sobre o organismo podem ser mais intensas, levando ao desgaste progressivo, às vezes, ao esgotamento, o que evidentemente compromete a performance do trabalhador. Este aspecto já tinha sido descrito por Selye (1956), quando descreveu a Síndrome da Adaptação em 1936, e Wolff, um dos fundadores e presidente da Sociedade Americana de Psicossomática, já em 1952, demonstrava que os distúrbios da relação do homem, com seu ambiente de trabalho, envolvendo aspecto físico e psicossocial, podem gerar emoções desprazerosas e propiciar reações de vários tipos, inclusive doenças (FRANÇA; RODRIGUES,1999).

Portanto, Wolff, em 1952, realizou dois tipos de estudos, que merecem ser citados: no primeiro, ao estudar a resposta do organismo humano a situações geradoras de insegurança e hostilidade, percebeu um aumento de fluxo sanguíneo, dos movimentos e das secreções no estômago das pessoas. No segundo, organizou dois grupos, um de indivíduos sem comprometimento físico e outro com pessoas que apresentavam distúrbio de estômago e de duodeno. Submeteram-se os dois grupos a uma situação de estresse agudo e verificou o seguinte: os dois grupos apresentaram respostas a nível corporal com aumento de produção de ácido clorídrico, muco, pepsina e aumento dos movimentos do estômago; em relação aos processos mentais, aumento da ansiedade, insegurança e sentimentos de culpa. Sendo que, no grupo que já apresentava sintomas físicos, durante o estudo tais reações foram mais intensas (FRANÇA; RODRIGUES, 1999).

Com isso, mais uma vez ficou demonstrado que o medo, a angústia, a frustração e a agressividade no trabalho podem aumentar as tensões cardíacas, musculares e digestivas. Sabe-se hoje que o ser humano é capaz de responder às ameaças decorrentes das interações sociais e não somente às ameaças concretas, como as biológicas, representadas pelos microoganismos e lou físicos e químicos.

A profissão, que utiliza muito a atividade mental, com responsabilidade em lidar com as pessoas e envolvida com os conflitos humanos, apresenta alta associação com doenças do sistema cardiovascular. Além de diversas outras manifestações e patologias associadas à sobrecarga de estresse ocupacional, como prisão de ventre, diarréia, úlcera, gastrite, dores musculares e na coluna, 
alergia, doenças de pele, coceiras, quedas de cabelo, cefaléia tensional, diminuição da libido, vertigens, asma, bronquite, câncer, entre outras (ALVES, 1992).

As principais síndromes e doenças associadas e/ou provocadas pelo estresse ocupacional são: somatizações, fadiga, distúrbios do sono, depressão, síndrome do pânico, síndrome de "Burnout"1 síndrome residual pós-traumática, quadros neuróticos pós-traumáticos, distúrbios osteomusculares relacionados ao trabalho (DORT) ou lesões por esforços repetitivos (LER), transtornos psicossomáticos, síndromes de insensibilidade, alcoolismo, uso de drogas ilícitas e outros (FRANÇA; RODRIGUES, 1999).

\subsection{Eventos geradores de estresse: Riscos psicossociais no trabalho que podem levar ao estresse}

Aquilo que gera estresse é chamado de estressor ou fonte de estresse. $O$ estressor pode ser algo negativo e também positivo que emociona a pessoa de modo marcante. Este termo tem sido definido como uma situação ou experiência que gera sentimentos de tensão, ansiedade, medo ou ameaça e que pode ser de origem interna ou externa (BARSTOW, 1980).

Existem vários tipos de estressores e muitas vezes o que estressa uma pessoa não estressa outra.

Atenção especial tem sido dispensada aos chamados estressores ocupacionais, isto é, tensões e problemas advindos do exercício de uma atividade profissional.

Pesquisadores concordam que existem fatores no ambiente de trabalho que podem causar estresse ocupacional, podendo este ser derivado de riscos físicos e riscos psicossociais. A exposição a riscos físicos e /ou psicossociais afeta tanto a saúde física do indivíduo bem como a psicológica (EUROPEAN AGENCY FOR SAFETY AND HEALTH AT WORK, 2000).

\footnotetext{
${ }^{1}$ A Síndrome de "Burnout”, segundo Malash (1994) é desenvolvida em resposta a fontes crônicas de estresse emocional e interpessoal no trabalho.
} 
Portanto o estresse ocupacional nos mostra dois cenários:

$\left.1^{\circ}\right) \mathrm{O}$ estresse associado com a exposição a riscos físicos

$\left.2^{\circ}\right) \mathrm{O}$ estresse associado com a exposição a riscos psicossociais

Uma grande variedade de riscos físicos tem sido extensivamente estudada pelos efeitos causados, tanto psicológicos como na saúde física dos indivíduos (HOLT, 1982). Muitos destes riscos podem ser medidos objetivamente e com algum grau de confiabilidade e validade e são também fáceis de monitorar no local de trabalho. Em alguns casos existem "padrões" que podem ser usados na regulação à exposição dessas potenciais fontes de prejuízos.

Smith (1991) tem concluído que existe considerável evidência de que a exposição a ruídos agudos produz respostas psicológicas que, se prolongadas, poderiam provocar perigosos efeitos na saúde.

Existem outros fatores físicos, além do ruído, que causam prejuízos para o trabalhador. Evidências sugerem que pobres condições físicas, no local de trabalho, podem afetar os trabalhadores na saúde física e psicológica deles, bem como levar à experiência de estresse (JENKINS; CONEY, 1992).

No caso de riscos físicos como a temperatura e umidade, somente em condições extremas é que estão associadas com a experiência de estresse e com efeitos na saúde (HOLT, 1982).

Além dos riscos físicos no ambiente de trabalho, há uma grande preocupação com alguns aspectos do trabalho que podem afetar a saúde do trabalhador, como é o caso dos riscos psicossociais.

Para Girdano; Everly (1979), as causas psicossociais são decorrentes da interação direta entre comportamento social e interpretação deste comportamento, com base em experiências passadas e outros processos de aprendizagem.

Os riscos psicossociais, através da experiência de estresse, podem afetar a saúde física e psicológica dos trabalhadores (EUROPEAN AGENCY FOR SAFETY AND HEALTH AT WORK, 2000).

Para a Organização Internacional do Trabalho-OIT (1984), os riscos psicossociais no trabalho consistem, por um lado, em interação entre o trabalho, seu ambiente, a satisfação no trabalho e as condições de sua organização; e, por outro, em capacidades do trabalhador, suas necessidades, sua cultura e sua situação pessoal fora do trabalho; o que afinal, através de percepções e experiências, pode influir na saúde, no rendimento e na satisfação no trabalho. 
Os riscos psicossociais do trabalho são experimentados como estressantes ou carregam de algum modo um potencial para o prejuízo no trabalho (KASL, 1992).

Alguns autores descrevem que os riscos psicossociais, presentes nas condições de trabalho, podem estar relacionados em diversas categorias dentro do contexto e conteúdo do trabalho. Estas categorias são: cultura e função organizacional, função na organização, desenvolvimento de carreira, decisão e controle, relacionamento interpessoal no trabalho, interface trabalho/família, ambiente de trabalho e equipamento de trabalho, planejamento das tarefas, cargas e local de trabalho e esquema de trabalho (COX et al., 2000). Cada uma dessas categorias, relacionadas a riscos psicossociais do trabalho, podem provocar estresse e problemas de saúde, e a seguir, no Quadro 1, serão descritas sobre elas. 
Quadro 1- Riscos psicossociais relacionados ao trabalho que podem causar estresse .

\begin{tabular}{|c|c|}
\hline CATEGORIAS & CONDIÇÕES DE RISCOS \\
\hline & Contexto do trabalho \\
\hline 1.Cultura e função organizacional & $\begin{array}{l}\text { Pobre comunicação, baixos níveis de suporte para } \\
\text { resolver problemas organizacionais para o } \\
\text { desenvolvimento pessoal, indefinição dos objetivos } \\
\text { organizacionais }\end{array}$ \\
\hline 2. Função na organização & $\begin{array}{l}\text { Ambigüidade e conflito de papéis, responsabilidade } \\
\text { por pessoas. }\end{array}$ \\
\hline 3. Desenvolvimento de carreira & $\begin{array}{l}\text { Estagnação e incerteza na carreira, insegurança no } \\
\text { trabalho, pouco valor social do trabalho. }\end{array}$ \\
\hline 4. Decisão e controle & $\begin{array}{l}\text { Pouca participação nas decisões, falta de controle } \\
\text { sobre o trabalho (controle, particularmente na forma de } \\
\text { participação). }\end{array}$ \\
\hline $\begin{array}{l}\text { 5.Relacionamento interpessoal no } \\
\text { Trabalho }\end{array}$ & $\begin{array}{l}\text { Isolamento físico e social, pobre relacionamento com } \\
\text { os supervisores, conflito interpessoal e falta de suporte } \\
\text { social }\end{array}$ \\
\hline 6. Interface trabalho/família & $\begin{array}{l}\text { Conflitos nas exigências do trabalho e do lar, pouco } \\
\text { suporte no lar, duplo problema na carreira }\end{array}$ \\
\hline & Conteúdo do Trabalho \\
\hline 7.Ambiente e equipamento de trabalho & 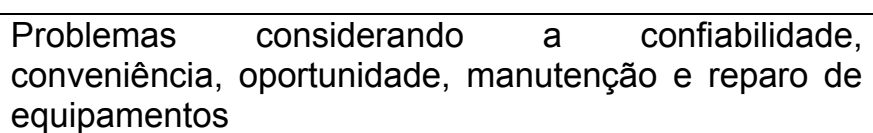 \\
\hline 8. Planejamento das tarefas & $\begin{array}{l}\text { Falta de variedade no trabalho, pouco uso das } \\
\text { habilidades, alto nível de incerteza, falta de } \\
\text { oportunidade para aprender, e outros. }\end{array}$ \\
\hline 9.Carga e ritmo de trabalho & $\begin{array}{l}\text { Sobrecarga e baixa carga de trabalho, altos níveis de } \\
\text { pressão no trabalho }\end{array}$ \\
\hline 10.Esquema de trabalho & $\begin{array}{l}\text { Esquemas de trabalho inflexíveis, horas inprevisíveis, } \\
\text { longas horas de trabalho. }\end{array}$ \\
\hline
\end{tabular}

Fonte: COX,T.;GRIFFITHS, A.J.; RIAL-GONZALEZ,E. Research on work-related Stress. Report to the European Agency for Safety and Health at Work 2000. Luxembourg. Office for Official Publications of the European Communities. Disponivel em: http://agency.osha.eu.int/publications/ reports/stress. Acesso em janeiro de 2005.

De acordo com Cox et al., (2000), existem vários riscos psicossociais relacionados ao contexto e conteúdo do trabalho e que são experimentados como estressantes e lou com potencial para causar prejuízo. Estes riscos estão representados sob vários aspectos relacionados à organização e ao ambiente de trabalho. 


\section{Categorias relativas ao contexto do trabalho}

-Cultura e função organizacional

Esta categoria envolve deficiência na comunicação, suporte precário para a resolução de problemas e para o desenvolvimento pessoal e indefinição de objetivos organizacionais (EUROPEAN AGENCY FOR SAFETY AND HEALTH AT WORK, 2000).

Estudos realizados com trabalhadores sobre a percepção e a descrição de sua própria organização, sugerem três aspectos distintos: a organização como um local de realização de tarefas, para resolver problemas e um local em desenvolvimento (COX ; LEITER, 1992). Quando a organização é percebida como um ambiente precário, provavelmente isto estará relacionado a um aumento do estresse. Contudo se a organização for percebida como boa nos aspectos anteriormente citados, então a relação entre a experiência ao estresse e o registro dos sintomas da doença será atenuada (COX; KUK, 1991).

Aspectos da organização têm sido considerados perigosos, por exemplo: estrutura, tamanho, procedimentos arbitrários e questões relacionadas à função (KASL,1992). Alguns efeitos da cultura e função da organização sobre os trabalhadores podem ser transmitidos por comportamento de gerentes e supervisores. Existe evidência de que a forma de gerenciar e o estilo de supervisão têm um impacto substancial no bem-estar emocional dos trabalhadores (LANDY, 1989).

- Função ou papel na organização

Estudos que enfocam riscos psicossociais relacionados ao estresse no trabalho têm se apoiado nas teorias de papéis que destacam como fatores principais o conflito e a ambigüidade de papéis (JEX, 1998). Entretanto outros aspectos potencialmente prejudiciais na função têm sido identificados, incluindo a sobrecarga de papéis e responsabilidade por outras pessoas (FRANÇA; RODRIGUES, 1999). 
O conflito de papéis ocorre quando um indivíduo é solicitado para fazer uma atividade que não está de acordo com os seus valores, ou quando várias funções que ele tem que realizar são incompatíveis umas com as outras.

Ocorrência deste tipo é muito comum no caso das mulheres que têm atividade profissional e têm que satisfazer o estereótipo masculino do trabalhador bem-sucedido, além de ter que cumprir as expectativas e compromisos com casa, filhos e marido. Freqüentemente estes dois papéis geram conflito (FRANÇA; RODRIGUES, 1999).

Kahn et al. (1964) mostraram que quanto maior o conflito de papéis menor a satisfação no trabalho e maior a tensão relacionada ao trabalho.

A "ambigüidade de papéis" ocorre quando um trabalhador tem inadequada informação sobre a sua função no trabalho. Numerosos eventos podem gerar ambigüidade de papéis, muitos deles relacionados às situações novas e mudanças (IVANCEVICK et al., 1990).

A ambiguidade de papéis se manifesta quando há falta de clareza das expectativas do trabalho e da falta de certeza sobre as responsabilidades no trabalho. O ambiente de trabalho pode gerar falta de confiança, insegurança, irritação, pouca tolerância e até mesmo rejeição, tornando-se fator gerador de estresse, à medida que a pessoa terá dificuldades de se situar nas tarefas que lhe cabem, e seu desempenho pode vir a ser prejudicado (FRANÇA; RODRIGUES, 1999).

A insuficiência de papéis refere-se a falhas na organização em utilizar o treinamento e as habilidades de cada trabalhador.

A responsabilidade por pessoas tem sido identificada como um potencial de estresse associado com questões de papéis do trabalhador.

Nas profissões onde há relacionamento interpessoal, a exaustão emocional e despersonalização podem ocorrer (LEITER,1991).

- Desenvolvimento de carreira

Esta categoria trata das questões relativas à estagnação e incerteza na carreira, insegurança no trabalho e pouco valor social do trabalho (COX et al., 2000). 
A expectativa no desenvolvimento de carreira pode ser uma fonte de estresse, particularmente em organizações que enfatizam a relação entre 0 desenvolvimento de carreira e competência ou mérito (EUROPEAN AGENCY FOR SAFETY AND HEALTH AT WORK, 2000). Marshall (1977) identificou fontes potenciais de estresse nesta área: a falta de seguridade no trabalho e status incongruente (frustração de não poder se desenvolver na carreira).

O medo de falhar pode gerar o rebaixamento de postos, aumentando o estresse quando os trabalhadores não são hábeis para se adaptar as suas expectativas e realidade do trabalho (ROBERSTON; COOPER, 1983).

Em se tratando da insegurança no trabalho, pode ser considerada uma das maiores fontes de ansiedade, particularmente se as organizações esperam compromisso de seus trabalhadores (PORTER, 1990).

Estudos mostram que a baixa remuneração tem efeito na capacidade dos trabalhadores em permanecerem saudáveis (WARR,1992). Homens e mulheres que trabalham em situação de estresse e com poucas recompensas têm um aumento significativo de mortalidade cardiovascular subseqüente (CARDIONEWS, 2005).

Um dos indicadores para avaliar o grau de satisfação de qualidade de vida no trabalho é a renda adequada. Esta renda é relativa à remuneração do trabalho em tempo integral, a qual tem padrões organizacionais predeterminados na cultura da empresa e em modelos ideológicos (FRANÇA;RODRIGUES, 1999).

A incongruência no status, o custo desta incongruência, foi pesquisada com trabalhadores da marinha, mostrando que o atraso promocional se relaciona a doenças psiquiátricas (EUROPEAN AGENCY FOR SAFETY AND HEALTH AT WORK, 2000).

-Decisão e controle

A pouca participação do trabalhador nas decisões e a falta de controle sobre o trabalho constituem-se em condições de risco evidenciadas no contexto do trabalho (COX et al.,2000).

Existem aspectos relacionados à participação como o status que deve também afetar a saúde e o comportamento destes indivíduos.

É desejável que os empregados planejem seu trabalho, controlem sua carga e tomem decisões sobre o trabalho a ser realizado e a forma de resolver os 
problemas (WARR, 1992). A responsabilidade para tomar decisões parece ser outra fonte de estresse.

A falta de controle sobre seu trabalho e a não-participação no processo de decisão, freqüentemente estão associadas aos sintomas de estresse, ansiedade, depressão, apatia e exaustão, baixa auto-estima, e aumento da incidência de sintomas cardiovasculares (TERRY; JIMIESON, 1999).

Pesquisas sugerem que onde existem muitas oportunidades de participar nas decisões, são registrados maiores índices de satisfação e sentimentos de autoestima (FRENCH ; CAPLAN, 1970). A falta de participação aparece relacionada ao estresse ocupacional (MARGOLIS et al., 1974).

- Relacionamento interpessoal no trabalho

Esta categoria está relacionada ao limitado e insuficiente relacionamento com os supervisores, ao conflito interpessoal, à falta de suporte social e violência no trabalho. Existem argumentos fortes de que bons relacionamentos entre trabalhadores e outros membros dos grupos de trabalho são essenciais para ambos, saúde individual e organizacional (COOPER, 1981).

Jones et al. (1988), encontrou registros de altos níveis de estresse em trabalhadores. Importantes grupos de relacionamento são identificados: superiores com subordinados e relacionamento com os próprios colegas (KEITA; SAUTER, 1992).

O sucesso de uma organização depende da performance individual, da qualidade da interação da associação no trabalho e da comunicação efetiva (WARREN ; TOLL, 1998). Ruídos na comunicação entre os trabalhadores que integram uma equipe podem gerar desmotivação no trabalho (MAIA, 2005) que, por sua vez, pode desencadear o estresse.

A qualidade das relações interpessoais é um outro fator importante na hora de determinar o potencial estressor (FORNÉS, 1994). O conflito no grupo de trabalho pode ser positivo quando estimula a busca para soluções do problema; no entanto, caso a situação de conflito seja contínua e ocorra a falta de coesão, poderá haver frustrações, insatisfação e favorecer o aparecimento de moléstias somáticas (PEIRÓ, 1993). 
Os benefícios psicológicos e físicos do suporte social têm sido pesquisados e seus resultados mostram que os profissionais com suporte controlam melhor os eventos estressantes e há redução de risco da mortalidade por doenças específicas (TAYLOR, 1991). Suporte interpessoal insuficiente no trabalho tem sido associado com ansiedade, exaustão emocional, tensão no trabalho, diminuição da satisfação no trabalho e aumento do risco de doenças cardiovasculares (WARR, 1992).

Outro risco que merece ser sublinhado é o da violência no trabalho. Há evidência de que a exposição à violência no local de trabalho pode causar prejuízos psicológicos bem como físicos (LEATHER et al.,1999).

A violência é um problema que está aumentando em toda a Europa. Milhões de trabalhadores reportam que são objeto de perseguição sexual, intimidação e violência psicológica (EUROPEAN FOUDATION, 1996). Como resultado deste problema, a Comissão Européia tem publicado guias de prevenção de violência no trabalho (WYNNE et al., 1997).

- Interface trabalho/família

A Interface trabalho/família é considerada de grande importância como risco psicossocial no trabalho, pois a esta categoria estão relacionadas questões como: conflitos nas exigências do trabalho e do lar e pouco suporte no lar.

A relação trabalho/família possui alguns problemas que envolvem a resolução de conflitos de exigências no tempo e compromisso e giram em torno de questões de suporte (HINGLEY; COOPER, 1986).

Algumas das principais áreas de conflito no trabalho/família que podem levar ao estresse são: sentir-se culpado por não estar em casa para cuidar das crianças; ressentimento por não ficar tempo suficiente com a família; ausência de vida social em virtude de horas de trabalho extremamente longas; exigências dos parentes dependentes em conflito com as responsabilidades do trabalho; não ganhar o suficiente para cobrir os gastos ou para satisfazer um estilo de vida desejável (WARREN; TOLL,1998).

As dificuldades face à resolução de conflitos entre trabalho e família aparecem aumentadas se a família possui uma criança pequena. Isto deve ser particular para as mulheres que trabalham (LARWOOD; WOOD, 1979). 
Os resultados de uma pesquisa, relacionando a influência da interferência família/trabalho sobre o estresse ocupacional, revelaram que esta pode favorecer 0 aparecimento de estressores organizacionais e influenciar afetos e cognições, que por sua vez, levam à percepção de demandas do trabalho como estressores (PASCHOAL, 2003).

Lundahl (1971) observou em seu estudo que aqueles trabalhadores que se apresentavam fatigados no trabalho mostraram menor envolvimento com o lazer do que aqueles que não estavam apresentando fadiga.

\section{Categorias relativas ao conteúdo do trabalho}

- Ambiente e equipamento de trabalho

Esta categoria refere-se a problemas relativos à confiabilidade, disponibilidade, à conveniência, a manutenção e reparo de equipamentos e facilidades.

Todos os equipamentos que compõem um posto de trabalho devem estar adequados às características psicofisiológicas dos trabalhadores e à natureza do trabalho a ser executado (SESCSP, 2005). A busca por um ambiente de qualidade deve ser uma preocupação dos administradores para atingir os objetivos das organizações. O ambiente de trabalho e os equipamentos irão repercutir diretamente na qualidade da assistência prestada.

- Planejamento das tarefas

No que diz respeito ao planejamento das tarefas, existem diferentes aspectos a esse respeito, relacionados ao conteúdo do trabalho que são prejudiciais. Estes incluem pouco valor no trabalho, monotonia das tarefas, pouca oportunidade de aprendizado e recursos insuficientes (KASL, 1992).

Ainda são citados outros aspectos como pouca ou nenhuma habilidade e a incerteza na realização das tarefas. 
A diversidade das tarefas tem uma relação significativa com a satisfação no trabalho. Quanto maior o número de estímulos novos, mais estressante a situação. Por outro lado, a pouca variedade das tarefas pode estar associada à ansiedade e depressão; o trabalho rotineiro e contínuo, durante anos, torna o trabalhador estagnado (PEIRÓ, 1993).

A incerteza no trabalho, sob a forma de falta de feedback da performance, é também uma fonte de estresse particularmente quando se estende por longo período de tempo (WARR, 1992).

- Carga e ritmo do trabalho

A saúde psicológica dos trabalhadores é diretamente relacionada às condições desagradáveis no trabalho, à necessidade de acelerar o ritmo do trabalho, à utilização de esforço físico e excessivas horas (KORNHAUSER, 1965).

A carga no trabalho foi um dos primeiros aspectos do trabalho a receber atenção, pois ela resulta de uma série de variáveis que dependem do indivíduo e das condições para realizar a tarefa, e tanto a sobrecarga como a baixa carga podem ser problemáticas (MAIA, 2005).

A carga de trabalho pode ser quantitativa e qualitativa (FRENCH et al., 1970). Ambas têm sido associadas com a experiência de estresse. A carga de trabalho quantitativa refere à quantidade de trabalho realizado, enquanto a qualitativa se refere ao grau de dificuldade do trabalho. As duas dimensões relacionadas à carga no trabalho são independentes, sendo possível haver trabalho que envolva sobrecarga quantitativa e baixa carga qualitativa.

Jones et al. (1988) encontraram trabalhadores reportando altos níveis de estresse relacionados a doenças por problemas nas "linhas de trabalho" e "sobrecarga de trabalho".

O ritmo do trabalho é a velocidade de sua execução. A natureza do controle emerge do ritmo da pessoa, do sistema ou da máquina (SAUTER et al., 1989). Existe uma forte evidência de que o ritmo do trabalho controlado por máquinas, particularmente se em alta velocidade, é prejudicial para a saúde física e psicológica (COX, 1985 ). 
- Esquema de trabalho

Existem duas questões relacionadas aos efeitos do esquema de trabalho na saúde: mudança no esquema ou função no trabalho e longas horas de trabalho.

Alterações no trabalho têm sido encontradas particularmente no trabalho noturno, por causarem interrupções dos ritmos circadianos e padrões de sono, longas horas no trabalho, se estendendo além de 12 horas diárias e vários dias de perda de sono. Estes fatores estão relacionados ao aumento da fadiga, performance prejudicada e acúmulo de débito de sono (STAMPI, 1989).

O controle sobre o esquema de trabalho é um importante fator no planejamento e organização do trabalho e a flexibilidade nos horários pode reduzir as situações de estresse (LANDY, 1989).

A vulnerabilidade dos indivíduos ao estresse depende da habilidade dos mesmos em lidar com os eventos estressores. A qualidade dos eventos estressores é importante, mas a maneira como o indivíduo reage a eles é fundamental para que se desenvolva um quadro de estresse. Uma vez que o modo de reagir a estímulos é um produto de aprendizagem, o contrário também pode ocorrer e é possível desaprender certas reações inadequadas e estressoras em potencial (LIPP, 1984).

\subsection{Controle e gerenciamento dos riscos inerentes ao estresse ocupacional}

Quando surgem o estresse e suas complicações, as queixas psicossomáticas significam que existem pressões externas que precisam ser compreendidas e gerenciadas para se atingir bem-estar e desempenho adequado no trabalho (FRANÇA; RODRIGUES, 1999).

Assim, os sintomas do estresse sinalizam tensões excessivas no organismo, problemas de adaptação, limites de resistência e vulnerabilidade pessoal ou ocupacional, ambientes insalubres, relacionamentos conflituosos, formas pessoais de reagir, mecanismos de sobrevivência e necessidade de ajuda (FRANÇA; RODRIGUES, 1999). 
Em uma situação de trabalho, para o controle do estresse, o diagnóstico dos sintomas de estresse é essencial, mas não é suficiente; o sucesso deste controle depende da identificação das fontes de estresse presentes, pois através desta, torna-se possível desenvolver estratégias para lidar não só com os episódios presentes, mas também com futuras ameaças de estresse (LIPP, 2003).

É inquestionável a importância de elaboração de estratégias de promoção à saúde, ou seja, intervenções que promovam resultados benéficos ao trabalhador a nível psicológico e fisiológico, minimizando assim os efeitos dos eventos geradores de estresse no trabalho.

O Guia da Comissão Européia que trata de "estresse no trabalho: tempero da vida ou beijo da morte" (EUROPEAN COMMISSION, 2000) descreve que existem algumas maneiras de melhorar o estresse relacionado ao trabalho. Uma das abordagens, consideradas de custo baixo para a organização é conhecida como "gerenciamento sistemático do ambiente de trabalho". Trata-se de um sistema auto-regulatório realizado em estreita colaboração entre as partes envolvidas. Segundo este guia, o gerenciamento sistemático pode ser coordenado por diversos profissionais como: inspetor de trabalho, enfermeira ocupacional ou de saúde pública, assistente social, fisioterapeuta ou administrador de recursos humanos. $O$ primeiro passo é identificar a incidência, a prevalência, a gravidade e as tendências em relação às exposições aos riscos relacionados ao trabalho e suas causas e conseqüências para a saúde, por exemplo. As características dessas exposições, conforme refletidas no conteúdo, organização e condições de trabalho, são analisadas em relação aos resultados encontrados. Para esta análise, algumas questões devem ser levantadas como: As características das exposições do trabalho seriam necessárias ou suficientes ao estresse no trabalho e problemas de saúde relacionados ao trabalho? Elas podem ser modificadas? Tais mudanças são aceitáveis às partes envolvidas?

Após esta etapa, as partes envolvidas podem projetar um pacote de intervenções integrado e implantá-lo a fim de prevenir o estresse relacionado ao trabalho, promovendo o bem-estar e aumentando a produtividade. Os resultados a curto e longo prazos advindos de tais intervenções necessitam ser avaliados .

Se as intervenções não têm efeitos, ou os efeitos são negativos em um ou mais aspectos, as partes envolvidas talvez queiram repensar o que deveria ser feito. Se por outro lado, os resultados forem de modo geral, positivos, elas podem querer 
continuar ou expandir seus esforços seguindo moldes semelhantes. Essa abordagem significa simplesmente aprender com a experiência de forma sistemática. Se isto for feito, considerando-se uma perspectiva mais longa, o local de trabalho torna-se um exemplo de aprendizagem organizacional. As experiências com tais intervenções geralmente são positivas, não apenas para os trabalhadores e em termos de estresse, saúde e bem-estar, mas também para a função e o sucesso das organizações de trabalho e para a comunidade.

Cox et al. (2000) têm descrito uma estratégia em cinco fases para ser executada no processo de avaliação dos riscos inerentes ao trabalho. As diferentes fases são sumarizadas em:

1) Familiarização;

2) Entrevistas de análise do trabalho;

3) Avaliação do levantamento realizado;

4) Auditoria da existência de Gerenciamento de Controle e Sistemas de Suporte para empregados ;

5) Análises e interpretação da avaliação dos dados.

Durante cada fase ou etapa, são coletadas várias informações. As etapas iniciais, um e dois, são designadas a levantar o modelo e as condições de trabalho. Após, é construído um instrumento de avaliação para ser aplicado (etapa três). Este instrumento é usado para quantificar a exposição dos trabalhadores a todos os estressores significantes associados ao trabalho, às condições de trabalho à avaliação de saúde deles.

As cinco etapas são largamente seqüenciais com uma possível exceção. A auditoria da existência de gerenciamento de controle e sistema de suporte para os trabalhadores (etapa quatro) pode ser conduzida em paralelo com a análise das entrevistas, ou concomitante à análise e interpretação dos dados. Finalmente, todas as informações são analisadas e interpretadas (etapa cinco).

Murphy (1984) fez uma revisão de vários estudos sobre intervenções para o gerenciamento do estresse, isto é, técnicas designadas a ajudar os trabalhadores a modificar situações estressantes e não prazerosas ou negociar mais efetivamente com os sintomas do estresse. Foram encontradas como técnicas mais comuns: o relaxamento dos músculos, meditação, "biofeedback" 2 , habilidades cognitivo-

\footnotetext{
${ }^{2}$ Segundo Neufeldt (1997) feedback é um processo no qual os fatores que produzem um resultado são modificados, corrigidos ou distendidos pelo resultado, e biofeedback é uma técnica que busca controlar certos
} 
comportamentais e combinações dessas técnicas. Os programas cognitivocomportamentais foram os mais efetivos para resultados psicológicos, enquanto os programas de relaxamento foram os mais efetivos para resultados fisiológicos.

Algumas estratégias podem ser desenvolvidas pelos trabalhadores, individualmente, no controle do estresse como (NACARATO, 1999):

- "Procurar ter saúde" Esta é uma atitude importante em qualquer fase da vida. Para a saúde, se requerem atitudes preventivas no sentido de se buscarem cuidados médicos constantemente. Especialmente em situações estressantes, uma quantidade maior de vitaminas será utilizada pelo organismo, havendo o desgaste e aumentando a probabilidade de doenças surgirem. Assim, uma alimentação saudável e balanceada é extremamente importante a fim de garantir a ingestão dos nutrientes necessários e evitar os excessos.

- "A prática de atividade física regular". Esta é uma estratégia de extrema importância no controle do estresse, favorecendo a produção no organismo de substâncias responsáveis pela sensação de bem-estar.

- "Saber relaxar". É uma atitude importante para manter o equilíbrio físico e mental, diminuindo estados de ansiedade e tensão.

Ao se considerar também a influência psicossocial na determinação dos sintomas de estresse, uma orientação psicológica pode permitir um melhor conhecimento sobre o próprio organismo na relação com o seu ambiente. $E$ mais, tal intervenção propiciará às pessoas odesenvolvimento de estratégias para lidar mais eficientemente com as situações estressantes do meio em que atuam.

Suporte social pode ser um recurso, se percebido como disponível, ou pode ser visto como uma estratégia de enfrentamento, quando a pessoa procura fontes de suporte para negociar com o estresse (LINDA, 1997).

Suporte social é importante em todas as situações de "prestar cuidado". Tem um significativo papel para as pessoas que cuidam no gerenciamento de qualquer relação de estresse que elas possam sentir (FINK, 1995).

Segundo GUIMARÃES (1999), para atravessar momentos difíceis da vida e compartilhar momentos de prazer, o suporte social representa uma grande fonte de recursos. 
Era muito freqüente no passado o gerenciamento do estresse ser considerado de responsabilidade do indivíduo. Entretanto, cada vez mais as organizações estão compreendendo que gerenciar o estresse pode trazer um lucro para elas próprias bem como para os seus trabalhadores (WARREN; TOLL, 1998). De acordo com estes autores, seria útil ter um programa de ação por escrito do gerenciamento do estresse no trabalho; isto pode fazer parte de uma política saudável sobre a qual todos os funcionários devem saber. Um gerente deve ter a responsabilidade por assegurar-se de que o programa seja implementado. Esta pessoa deve observar se existem formas de monitorar os níveis de estresse e de remover quaisquer causas desnecessárias de estresse. Também é preciso que haja recursos e oportunidades para ajudar tanto a organização como o trabalhador a tomarem atitudes para melhorar a situação.

Alguns autores fazem recomendações de como mudar a organização para prevenir o estresse no trabalho (KEITA; SAUTER, 1992):

- Assegurar que a carga de trabalho está de acordo com a capacidade e recursos dos trabalhadores;

- O planejamento das tarefas deve promover estimulação e oportunidades para os trabalhadores utilizarem suas habilidades;

- Definir claramente os papéis e responsabilidades dos trabalhadores

-Proporcionar oportunidades para os trabalhadores participarem nas decisões sobre suas tarefas;

-Melhorar a comunicação na redução de incertezas sobre o desenvolvimento de carreira e futuro desenvolvimento de prospectos;

-Providenciar oportunidades para a interação social entre os trabalhadores;

-Estabelecer esquemas de trabalho que são compatíveis com as exigências e responsabilidades fora do trabalho.

Ao analisarmos essas recomendações, podemos relacioná-las aos riscos psicossociais ligados ao trabalho, que quando presentes podem levar ao estresse profissional.

Pela literatura científica, observamos que existe maior preocupação com a avaliação dos riscos do que com o seu gerenciamento. O gerenciamento do estresse pode ser classificado de acordo com seus objetivos e estratégias, seu foco ou alvo, e o agente através do qual ele é realizado (NEWMAN; BEERHS, 1979). 
Pesquisadores fazem distinção entre os objetivos para o controle do estresse que se preocupam ou focalizam a organização (gerenciamento do estresse organizacional) e aqueles cuja preocupação é o indivíduo (gerenciamento do estresse individual), (IVANCEVICK etal., 1990; MURPHY, 1984; NEWMAN; BEEHR, 1979).

Os serviços de apoio a profissionais de saúde, que se apresentam como serviços preventivos ou de recuperação, devem ajudá-los. A orientação fundamental destes serviços é para auxiliar os profissionais da saúde a enfrentar sua possível reação de estresse que pode vir a interferir efetivamente na qualidade de sua assistência. Os serviços devem ter o objetivo de restaurar o equilíbrio e funcionamento psicobiológico do indivíduo, para pelo menos amenizar problemas de estresse presentes (BAILEY, 1985).

As práticas terapêuticas a serem oferecidas pela empresa dependem de fatores particulares da cultura e atividade de cada instituição, desde o espaço disponível e o número e especialidade da equipe de saúde, ao grau de risco das ocupações e política de saúde da instituição. A interação indivíduo/trabalho/saúde necessita de uma visão integradora que leve a ações terapêuticas (FRANÇA; RODRIGUES, 1999).

\subsection{Modelo de assistência de Saúde da Família}

\subsubsection{Conceito e objetivos}

Para o processo de reorganização da atenção básica à saúde, o Ministério da Saúde, em 1994, propõe a estratégia de Saúde da Família com a certeza de que as mesmas já constituem uma realidade concreta no contexto da mudança do modelo assistencial no qual o país está empenhado (BRASIL, 1994).

Esta nova estratégia do setor saúde deve ser entendida como uma forma de substituição do modelo vigente, plenamente sintonizada com os princípios da universalidade e eqüidade da atenção, e da integralidade das ações e, acima de tudo, voltada à permanente defesa da vida do cidadão. Esta estratégia está estruturada na lógica da atenção básica à saúde, gerando novas práticas setoriais e afirmando a indissociabilidade entre os trabalhos clínicos e a promoção da saúde. 
A estratégia de Saúde da Família tem como pressuposto básico o trabalho em equipe, composta de vários profissionais de nível superior e médio, com o objetivo de realizar uma intervenção de caráter primordialmente preventivo e de promoção à saúde, em uma população territorialmente adscrita, visando especialmente à educação de grupos de risco, com maior propensão a adoecer ou a complicar, em função, muitas vezes, da falta de informação (SANTOS;CUTOLO, 2003).

Neste modelo de assistência, a atenção está centrada na família entendida e percebida a partir do seu ambiente físico e social, o que vem possibilitando às equipes multiprofissionais uma compreensão ampliada do processo saúde/doença e da necessidade de intervenção que vai além de práticas curativas (BRASIL,1998).

Para tanto, se faz necessário que uma nova relação se estabeleça entre os profissionais de saúde e a comunidade, que se traduza em termos de desenvolvimento de ações mais humanizadas, tecnicamente competentes, intersetorialmente articuladas e socialmente apropriadas. Configura-se, também, uma nova concepção de trabalho e formação de vínculo entre os membros de uma equipe, permitindo maior diversidade das ações e busca permanente de consenso. Tal relação, baseada na interdisciplinaridade, requer uma abordagem que estimule a permanente comunicação horizontal entre os trabalhadores.

A equipe, conforme trabalha com indivíduos e famílias, reconhece e compreende como a saúde de cada membro influencia a unidade familiar que, por sua vez, age sobre a saúde de cada indivíduo, incorporando este conhecimento ao plano de cuidado.

Assistir família é pensar na estruturação do plano assistencial; é por exemplo ser capaz de perguntar-se: Como a doença da mãe afeta o cuidado da criança? Como o pai responde à doença da mãe e ao cuidado da criança? Como o funcionamento da família é afetado pela doença da mãe? Como a família enfrenta esta situação? Como utiliza os recursos da comunidade? Assim, a Equipe de Saúde deve ser capaz de compreender que assistir famílias implica conhecer o seu funcionamento e os fatores que influenciam as experiências da família na saúde e/ou na doença.

Para assistir as famílias torna-se necessário a implantação de unidades de Saúde da Família que consistem em unidades ambulatoriais públicas de saúde destinadas a realizar assistência contínua nas especialidades básicas, por meio de equipe multiprofissional. 
Essas desenvolvem ações de promoção, prevenção, diagnóstico precoce, tratamento e reabilitação, características do nível primário de atenção, tendo como campos de intervenção o indivíduo, a família, o ambulatório, a comunidade e o meio ambiente. A unidade deve, portanto, estar vinculada à rede de serviços, de forma que se garanta atenção integral aos indivíduos e famílias, e sejam asseguradas a referência e contra-referência para clínicas e serviços de maior complexidade, sempre que o estado de saúde da pessoa exigir (SANTANA; CARMAGNANI, 2001).

A unidade de saúde da família trabalha com definição de território de abrangência, que significa a área que está sob sua responsabilidade; pode atuar com uma ou mais equipes de profissionais, a depender da área de abrangência e do número de habitantes vinculados a esta unidade.

O processo de planejamento das ações de saúde deve ser pensado como um todo e direcionado à resolução dos problemas identificados no território de responsabilidade da unidade de saúde, visando à melhoria progressiva das condições de saúde e da qualidade de vida da população assistida.

\subsubsection{A Equipe de Saúde da Família}

Para que se exerça esta nova prática, são necessárias ações voltadas ao redirecionamento da participação dos profissionais de saúde, com vistas à construção da equipe de saúde como a verdadeira unidade produtora desses serviços. A especificidade das responsabilidades de cada membro jamais deverá ofuscar a missão comum da equipe, e sua prática democrática e construtiva necessita estar direcionada a uma maior motivação, satisfação e eficiência de seu trabalho (BRASIL, 2000).

Uma equipe de profissionais de saúde da família pode ser responsável, no âmbito de abrangência de uma unidade de saúde da família, por uma área onde residam, no máximo 1.000 (mil) famílias ou 4.500 (quatro mil e quinhentas) pessoas.

Recomenda-se que uma equipe deva ser composta minimamente pelos seguintes profissionais: médico, enfermeiro, dentista, auxiliar de enfermagem e agentes comunitários de saúde (na proporção de um agente para no máximo 150 famílias ou 750 pessoas). Outros profissionais - a exemplo de assistentes sociais e psicólogos - poderão ser incorporados às equipes ou formar equipes de apoio, de acordo com as necessidades e possibilidades locais. 
Os profissionais das Equipes de Saúde da Família devem residir no município onde atuam, trabalhando em regime de dedicação integral.

De acordo com o Ministério da Saúde, as atribuições básicas de uma Equipe de Saúde da Família são:

. Conhecer a realidade das famílias pelas quais são responsáveis;

- Identificar os problemas de saúde mais comuns e situações de risco no qual a população está exposta;

- Elaborar, com a participação da comunidade, um plano local para o enfrentamento dos fatores que colocam em risco a saúde;

. Programar as atividades e reestruturar o processo de trabalho;

- Executar, de acordo com a qualificação de cada profissional, os procedimentos de vigilância à saúde e de vigilância epidemiológica nos diversos ciclos da vida;

- Valorizar relação com o usuário e com a família para a criação de vínculo de confiança, que é fundamental no processo de cuidar;

- Resolver a maior parte dos problemas de saúde detectados e, quando isso não for possível, garantir a continuidade do tratamento, através da adequada referência do caso;

.Prestar assistência integral, respondendo de forma contínua e racionalizada à demanda, buscando contactos com indivíduos sadios ou doentes, visando a promover a saúde através da educação sanitária;

- Desenvolver processos educativos através de grupos voltados à recuperação da auto-estima, troca de experiências, apoio mútuo e melhoria do autocuidado;

- Promover ações intersetoriais e parcerias com organizações formais e informais existentes na comunidade para o enfrentamento conjunto dos problemas;

- Promover, através da educação continuada, a qualidade de vida e contribuir para que o meio ambiente torne-se mais saudável;

- Discutir de forma permanente, junto à equipe e à comunidade, o conceito de cidadania enfatizando os direitos de saúde e as bases legais que os legitimam;

- Incentivar a formação e/ou participação ativa nos Conselhos Locais de Saúde e no Conselho Municipal de Saúde. 
Existem atribuições específicas preconizadas pelo MS para alguns membros da ESF, as quais descrevemos a seguir.

Preferencialmente, o médico da equipe deve ser um generalista e, portanto, atender a todos os componentes das famílias independente do sexo e idade. Esse profissional deverá comprometer-se com a pessoa, inserida em seu contexto biopsicossocial, e não com um conjunto de conhecimentos específicos ou grupos de doenças. Sua atuação não deve estar restrita a problemas de saúde rigorosamente definidos. Seu compromisso envolve ações que serão realizadas enquanto ainda estão saudáveis. Ressalta-se que o profissional deve procurar compreender a doença em seu contexto pessoal, familiar e social. Suas atribuições básicas são: prestar assistência integral aos indivíduos sob sua responsabilidade; valorizar a relação médico/paciente e médico/família como parte de um processo terapêutico e de confiança; oportunizar os contatos com indivíduos sadios ou doentes, visando a abordar os aspectos preventivos e de educação sanitária; empenhar-se em manter seus clientes saudáveis, quer venham às consultas ou não; executar ações básicas de vigilância epidemiológica e sanitária em sua área de abrangência; executar as ações de assistência nas áreas de atenção à criança, ao adolescente, à mulher, ao trabalhador, ao adulto e ao idoso, realizando também atendimentos de primeiro cuidado nas urgências e pequenas cirurgias ambulatoriais, entre outras (BRASIL, 1998).

O profissional enfermeiro deve no âmbito de suas atribuições exercer a função de instrutor-supervisor, na proporção de no máximo 30 agentes comunitários de saúde para 01 (um) enfermeiro.

O enfermeiro desenvolve seu trabalho na unidade de saúde, junto à equipe de profissionais e na comunidade, apoiando e supervisionando o trabalho dos agentes comunitários de saúde, bem como assistindo as pessoas que necessitam de atenção de enfermagem. A capacitação do agente comunitário deve ocorrer em serviço, de forma continuada, sob a responsabilidade do enfermeiro.

Quanto às atribuições básicas, de acordo com o preconizado pelo Ministério de Saúde, o enfermeiro deve: executar, no nível de sua competência, ações de assistência básica de vigilância epidemiológica e sanitária nas áreas de atenção à criança, à mulher, ao adolescente, ao adulto e ao idoso; desenvolver ações para capacitação dos agentes comunitários de saúde e auxiliares de enfermagem, com vistas ao desempenho de suas funções junto ao serviço de 
saúde; promover a qualidade de vida e contribuir para que o meio ambiente torne-se mais saudável, entre outras.

As ações do auxiliar de enfermagem são desenvolvidas nos espaços da unidade de saúde e no domicílio/comunidade e este deve desenvolver, com os agentes comunitários de saúde, as atividades de identificação das famílias de risco, contribuir quando solicitado com os agentes comunitários nas visitas domiciliares e acompanhar consultas de enfermagem dos indivíduos expostos às situações de risco, visando a garantir um melhor monitoramento de suas condições de saúde (BRASIL, 1998).

Os agentes comunitários de saúde, por sua vez, desenvolvem suas ações nos domicílios de sua área de abrangência e junto à unidade para programação e supervisão de suas atividades. Algumas de suas atribuições são: cadastramento das famílias através de visitas domiciliares, mapeamento, identificação de microáreas de risco, acompanhamento mensal de todas as famílias sob sua responsabilidade, orientação, promover educação em saúde e mobilização comunitária; incentivar a formação de conselhos locais de saúde e orientar as famílias para a utilização adequada dos serviços de saúde.

A equipe de saúde da família pode enfrentar dificuldades na comunicação, pelo fato de envolver, na mesma equipe, vários sujeitos, com formações diferentes, que devem trabalhar em prol de objetivos comuns. Talvez o caráter distinto dessa equipe, em relação às demais, seja o grau de cooperação e complementariedade, o requerimento de discussão na tomada de decisões que devam ser pactuadas e o planejamento mais amiúde: o que implica em responsabilidades compartilhadas entre os atores envolvidos.

\subsubsection{O processo de trabalho das Equipes de Saúde da Família}

Para assistir a população é preciso estruturar as equipes de saúde com perfis profissionais necessários para enfrentar os problemas da realidade sanitária, bem como para se articular com outros setores que influenciam sobremaneira na resolutividade dos mesmos (CORNETA et al., 1996). 
Compreendemos que a Saúde da Família pode se abrir para além de um trabalho técnico hierarquizado, para um trabalho com interação social entre os trabalhadores, com maior horizontalidade e flexibilidade dos diferentes poderes, possibilitando maior autonomia e criatividade dos agentes e maior integração da equipe ( ALMEIDA; MISHIMA, 2001).

Sem dúvida, este processo exige a formação, capacitação e supervisão permanente dos profissionais envolvidos.

O trabalho em equipe na Saúde da Família requer a compreensão das várias disciplinas para lidar com a complexidade que é a atenção primária, a qual toma a saúde no seu contexto pessoal, familiar e social, bem como a promoção, prevenção e reabilitação da saúde (ALMEIDA; MISHIMA, 2001).

É importante assinalar que as atribuições técnicas de cada um dos profissionais da equipe mínima - médico, enfermeiro, auxiliar de enfermagem e agente comunitário de saúde - encontram-se arroladas no documento do Ministério da Saúde (Brasil, 1998, p.13), sendo inclusive enfatizado que o profissional do Programa de Saúde da Família (PSF) precisa ser capaz de atuar com criatividade e senso crítico, mediante uma prática humanizada e competente que envolva ações de promoção, prevenção, recuperação e reabilitação. Deve ser capaz de planejar, organizar, desenvolver e avaliar ações que respondam às necessidades da comunidade, articulando os diversos setores envolvidos na Promoção da Saúde (BRASIL, 1998).

Contudo, um rol de atividades e funções, buscando definir um perfil mínimo para atuação, não é suficiente para um trabalho em saúde compartilhado, humanizado, com responsabilização e vínculo com a comunidade, reconhecendo a saúde como direito de cidadania (ALMEIDA; MISHIMA, 2001). Quando consideramos que a unidade produtora dos serviços de saúde não é um profissional isoladamente, mas sim a equipe, a assistência à saúde passa a ter características centrais de um trabalho coletivo e complexo.

As escolas de formação detêm importante papel na capacitação de profissionais hábeis para a realização de tarefas complexas e diversificadas. É preciso formar profissionais que se insiram na realidade da população, criando vínculos e soluções criativas para a convivência harmoniosa e produtiva entre os vários saberes na área da saúde. 
Um processo de capacitação e informação contínuo e eficaz das equipes é necessário, de modo a poder atender às necessidades trazidas pelo dinamismo dos problemas, possibilitando um aperfeiçoamento profissional através da educação permanente.

A supervisão é um instrumento que deve ser utilizado, pois (...) "o trabalho que se organiza em bases coletivas carece de integração e de atividades que the confira unidade" (...) (SILVA, 1991:134).

O Ministério da Saúde, em seu "Guia de Supervisão em Estabelecimentos de Saúde (1991) define "supervisão como um processo educativo e contínuo, que consiste principalmente em motivar e orientar os supervisionados na execução de atividade com base em normas, a fim de manter elevada a qualidade dos serviços prestados" (BRASIL, 1983).

Dizer que o profissional de saúde da família está habilitado para exercer a sua função, implica uma compreensão humana das situações com as quais se depara, buscando a promoção social e da comunidade como a forma de ter uma comunidade mais saudável. Implica a apropriação de conceitos sobre a educação de adultos, sobre comunicação social, geografia e filosofia (WAGNER, 1996).

A aproximação com a comunidade requer o mínimo de tempo da equipe, conhecimento da saúde da família e habilidades clínicas. Para Wikes et al. (1997), o aumento do contato face a face com o cliente amplia a necessidade para habilidades terapêuticas ou de bem-estar. Estes autores, ao investigarem se o cuidado na comunidade é sustentável, examinando o estresse e a exaustão física e mental que afetam a saúde mental da equipe que presta assistência, observaram que a equipe experimentou altos níveis de estresse e exaustão física e mental como uma conseqüência de estressores no trabalho. Semelhantes dados foram encontrados quando examinamos níveis de estresse nos profissionais de Equipes de Saúde da Família (CAMELO; ANGERAMI, 2004). Pudemos comprovar através deste estudo com Equipes de Saúde da Família a ocorrência de estresse nestes trabalhadores. Constatamos que $62 \%$ dos trabalhadores investigados apresentavam estresse, sendo que $83 \%$ deles estavam na $2^{\text {a }}$ fase do processo ou fase de resistência. Também foi observada neste estudo a predominância de sintomas psicológicos em $48 \%$ dos sujeitos.

A presença de sintomas de estresse identificado nos trabalhadores das Equipes de Saúde da Família, somados a complexidade e diversidade das tarefas 
desenvolvidas por estes profissionais, com base no modelo preconizado pelo Ministério da Saúde, nos levaram a olhar para o seu trabalho, como propício a apresentar riscos psicossociais relacionados a aspectos de planejamento, organização e gerenciamento do trabalho, e ao seu contexto social e ambiental, que podem levar ao estresse. 
4 METODOLOGIA 


\subsection{Cenário do estudo}

\subsubsection{Características sociais e demográficas do município}

A cidade de São Sebastião do Ribeirão Preto, fundada a 19 de junho de 1856, constitui-se em importante centro regional de comércio e serviços do Estado de São Paulo. O município é o grande abastecedor de uma rica região que apresenta índices de qualidade de vida semelhantes aos de países desenvolvidos.

Localiza-se ao nordeste do Estado de São Paulo, a $313 \mathrm{~km}$ da capital, a uma altitude de 518 metros acima do mar. A cidade apresenta clima tropical com verão chuvoso e inverno seco, com temperatura oscilando entre $10{ }^{\circ} \mathrm{C}$ e $34^{\circ} \mathrm{C}$. Na primavera e verão, a temperatura chega a atingir mais de $38^{\circ} \mathrm{C}$ (URBANO, 2003).

Com cerca de 505.012 habitantes segundo o Censo Demográfico do IBGE de 2000, o município de Ribeirão Preto se encontra entre os maiores do Estado de São Paulo e do Brasil.

O município apresentou elevadas taxas de crescimento demográfico nas duas últimas décadas, situando-se sempre acima da média estadual, levando assim a um aumento de sua participação em relação ao Estado de São Paulo. Este desempenho se deve aos fluxos migratórios atraídos pelo dinamismo econômico do município e sua elevada qualidade de vida.

A estrutura etária da população é semelhante a do Estado de São Paulo com uma forte concentração na idade ativa, ou seja, entre 15 e 64 anos. Outro fator importante que merece ser destacado está relacionado à elevada taxa de urbanização, Ribeirão Preto possui cerca de 99\% da população vivendo na área urbana (RIBEIRÃO PRETO, 2005).

Dados da Companhia de Desenvolvimento Econômico de Ribeirão Preto (CODERP) referem que, em novembro de 1998, 99\% dos domicílios do município são servidos por água tratada e $96 \%$ deles ligados à rede de esgotos. 0 abastecimento de energia elétrica atende 100\% de suas habitações e indústrias urbanas.

A coleta de lixo urbano é universalizada e depositada em aterro sanitário. O antigo depósito de lixo que era feito "a céu aberto" representava perigo de 
contaminação do lençol aqüífero e, portanto, está sendo objeto de controle freqüente para evitar essa contaminação. A coleta seletiva do lixo já está sendo realizada em alguns bairros (URBANO,2003).

Dessa forma, podemos dizer que o município oferece uma razoável rede de serviços de engenharia sanitária que, conseqüentemente, devem melhorar as condições de saúde da população.

Ribeirão Preto destaca-se por uma ampla rede educacional que vai do ensino básico ao universitário. Como pólo universitário, a cidade atrai muitos estudantes da região, principalmente no ensino superior. Com mais de 110.000 jovens matriculados nos ensinos fundamental e médio, sendo que a relação aluno por docente é de 25,2 alunos de ensino fundamental por docente e 19,2 alunos no ensino médio por docente, resultado levemente inferior ao do Estado de São Paulo, demonstrando os esforços deste setor em prestar um serviço de qualidade nesta área.

\subsubsection{Setor Saúde}

A Política Municipal de Saúde de Ribeirão Preto tem por objetivo proteger e promover a saúde, diminuindo o risco da doença e outros agravos, bem como garantir o acesso universal e igualitário da população às ações e serviços de prevenção, diagnóstico, tratamento e reabilitação (RIBEIRÃO PRETO, 2005).

O município encontra-se em Gestão Plena do Sistema de Saúde, conforme a NOB-SUS 01/96, publicado em Diário Oficial da União, através da Portaria 2553 de 04 de maio de 1998.

O modelo de assistência à saúde presente hoje no município é do tipo clínico-assistencial com tendência à especialização, medicalização e sofisticação tecnológica, e isto é válido para todos os setores: municipal, estadual, conveniado e privado (URBANO, 2003).

A rede de saúde do município é formada por serviços estaduais, pela rede municipal e por serviços filantrópicos e particulares conveniados. Fazem parte também desta rede as Faculdades de Medicina, Odontologia, Ciências Farmacêuticas, Enfermagem, Psicologia da USP e algumas faculdades particulares 
como Medicina, Odontologia, Enfermagem, Fisioterapia e Ciências Farmacêuticas da UNAERP e Ciências Biomédicas e Enfermagem da Faculdade Barão de Mauá e Enfermagem da Universidade Paulista (UNIP).

$\mathrm{Na}$ rede pública municipal, podemos observar alta demanda para consulta médica, procedimentos odontológicos e de enfermagem, com a existência de uma grande concentração de ações para um mesmo agravo à saúde. Existe uma tendência ao atendimento despersonalizado sem vínculo usuário/profissional, o que compromete sua resolutividade e estimula a rotatividade dos pacientes pelos diversos serviços.

As unidades da rede municipal realizam atividades prioritariamente dirigidas à demanda espontânea da população, apesar da existência de programas de saúde, como o PACs e PSF, que estão sendo implementados e implantados em todas as unidades.

$\mathrm{Na}$ tentativa de compatibilizar as necessidades advindas do crescimento do município com a melhora do acesso da população aos serviços de saúde, organizou-se a assistência em Distritos de Saúde. Estes estão localizados nas Regiões: Norte - Distrito do Simioni, Sul - Distrito de Vila Virgínia, Leste - Distrito de Castelo Branco, Oeste - Distrito de Sumarezinho e Região Central - Distrito Central.

Os Distritos de Saúde são regiões com áreas e populações definidas a partir de aspectos geográficos, econômicos e sociais, que agrupam várias Unidades de Saúde e outros equipamentos sociais, conforme organograma (Figura 2). A distribuição das Unidades em Distritos visa a oferecer aos munícipes um atendimento básico e de pronto-atendimento em urgências/emergências próximo à sua residência e tornar mais acessível o atendimento de algumas especialidades encontradas nas UBDS $_{\text {s. }}$

Cada Distrito de Saúde possui Unidade Básica e Distrital de Saúde (UBDS), que, além do atendimento básico para sua área de abrangência, será a referência de algumas especialidades para todo o distrito. Além disto, cada Distrito é composto por várias Unidades Básicas de Saúde (UBS) que têm como finalidade prestar atendimento básico nas áreas médicas, odontológicas e de enfermagem, 
para a população de sua área de abrangência. As $\mathrm{UBS}_{\mathrm{s}}$ oferecem também imunização, entrega e aplicação de medicações.

Todas as unidades contam com a retaguarda de laboratório clínico, ultrasonografia, radiologia simples e eletrocardiografia. Nas distritais e ambulatórios de especialidades, também são realizados exames mais sofisticados através dos serviços contratados e/ou conveniados.

O sistema de referência apresenta todos os fluxos de agendamento definidos para as especialidades existentes na rede, porém a contra-referência não tem sido praticada na rotina dos serviços.

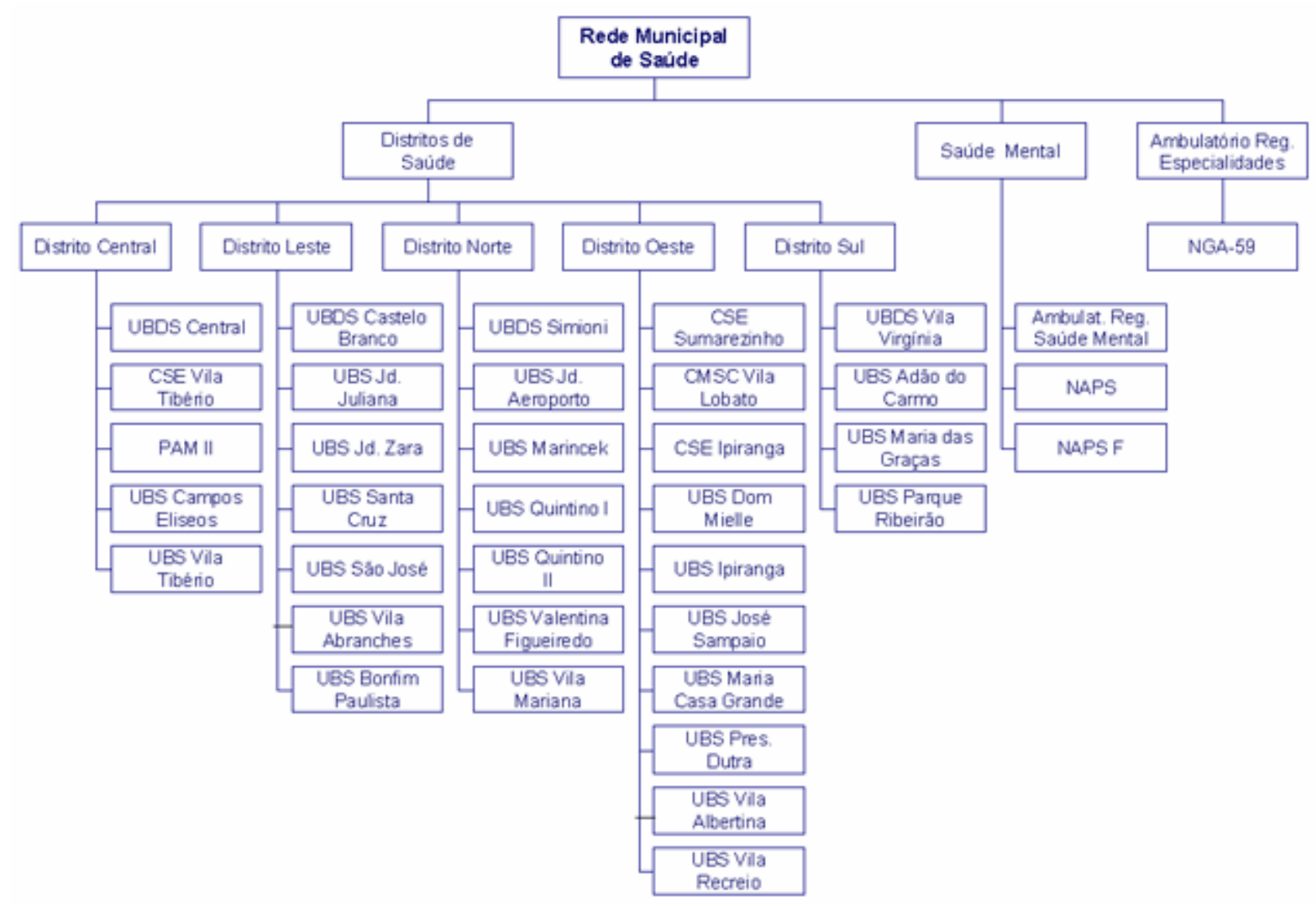

Figura 2- Organograma das Unidades Básicas de Saúde da Rede Municipal de Ribeirão Preto, 2005. Fonte: RIBEIRÃO PRETO. Características gerais do município. Prefeitura Municipal de Ribeirão Preto, SP. Disponível em : http://www.ribeiraopreto.sp.gov.br/SSAUDE/Vigilância/Planeja//16 plano.htm. Ribeirão Preto, 2005. 
No ano de 2006, conforme Plano de Saúde da Secretaria Municipal de Saúde do período de 2005- 2008, a rede pública ambulatorial é constituída por cinco Unidades Básicas Distritais de Saúde, 30 Unidades Básicas de Saúde, 3 Centros de Saúde Escola, que são Unidades Básicas que funcionam em parceria com a Faculdade de Medicina de Ribeirão Preto- Universidade de São Paulo, e 11 Unidades Especializadas: Ambulatório Regional de Saúde Mental, Ambulatório de Saúde Mental do Distrito Central, CAPS- Centro de Atenção Psicossocial, Núcleo de Atenção Psicossocial para Alcoolistas e Farmacodependentes, Núcleo de Saúde Mental do Distrito Sumarezinho, Núcleo de Gestão Assistencial- NGA-59, Centro Referência em Moléstias Infectocontagiosas "DR. José Roberto Campi" e Núcleo de Atenção à Pessoa Deficiente, Centro de Referência de Saúde do trabalhador e Ambulatório Geral de Especialidades Pediátricas (PAN II) (RIBEIRÃO PRETO, 2005a).

No âmbito local, a Secretaria Municipal da Saúde também está trabalhando na reorientação do modelo assistencial com a intenção de mudança do modelo centrado na assistência médica individual curativa para um modelo que contemple uma atenção integral do indivíduo, tendo por base a saúde coletiva (RIBEIRÃO PRETO, 2005).

A implantação do Programa de Saúde da Família- PSF tornou-se uma alternativa para a reorganização da atenção básica sendo adotada como uma estratégia inicial de reorientação do modelo assistencial, tendo a família e seu território como alvos essenciais, o que implicará na necessidade de um sistema eficaz de referência e contra-referência entre níveis de atenção e uma interface com outros setores sociais na solução dos problemas identificados, na busca de assistência eficiente e de qualidade de vida (RIBEIRÃO PRETO, 2005).

O município de Ribeirão Preto no momento dispõe de 18 Equipes de Saúde da Família inseridas em seis Unidades de Saúde mantidas exclusivamente pela Secretaria Municipal, cinco Núcleos de Saúde da Família, onde atuam conjuntamente SMS, Faculdade de Medicina de Ribeirão Preto-USP, Escola de Enfermagem-USP e Fundação de Apoio ao Ensino, Pesquisa e Assistência do Hospital das Clínicas da Faculdade de Medicina de Ribeirão Preto da Universidade de São Paulo-FAEPA e uma Unidade de Saúde da Família onde atuam conjuntamente a SMS e uma Instituição de Ensino Superior privada . 


\subsubsection{Unidade de Campo}

Nesta pesquisa, a unidade de campo ou análise, estabelecida para o desenvolvimento do estudo, foi constituída pelas Unidades de Saúde que apresentam Equipes de Saúde da Família mantidas exclusivamente pela Secretaria Municipal da Saúde de Ribeirão Preto e qualificadas até dezembro de 2004.

Esta escolha ocorreu com base na organização do trabalho destas equipes. Embora os objetivos e as atividades a serem desenvolvidas pelas equipes sejam semelhantes, as equipes pertencentes aos núcleos de Saúde da Família são gerenciadas por várias instituições, ocorrendo diferenças na organização do trabalho.

Assim, temos nove equipes de Saúde da Família distribuídas em cinco unidades Básicas de Saúde e uma Unidade de Saúde da Família, sendo:

- A Unidade Básica de Saúde-Aymar Baptista Prado, no bairro do D. Mielle que possui duas equipes mínimas (composta por médicos, enfermeiros, auxiliares de enfermagem e agentes comunitários de saúde) e uma equipe de saúde bucal ( composta por cirurgião dentista e auxiliar de cirurgião dentista).

- A Unidade Básica -Sérgio B. da Costa, no bairro Jardim Presidente Dutra com uma equipe mínima e uma equipe de saúde bucal estabelecidas dentro da própria unidade;

- A Unidade Básica de Saúde-Ernesto Guevara, no bairro Maria Casa Grande, possui duas equipes mínimas e duas equipes de saúde bucal;

- A Unidade Básica de Saúde - Adalberto T. Andrade (Vila Recreio) composta por uma equipe mínima e uma equipe de saúde bucal;

- A Unidade Básica de Saúde - Alberto Sabin(Marincek) composta por uma equipe mínima e uma equipe de saúde bucal, e a

- A Unidade de Saúde da Família-Jardim Heitor Higon, estabelecido dentro da área de abrangência da Unidade do Marincek, possuindo duas Equipes de Saúde da Família e duas equipes de saúde bucal.

As Unidades oferecem atendimento básico nas seguintes áreas: clínica médica, pediatria, ginecologia e odontologia, além do acompanhamento das famílias cadastradas, assistência domiciliar, teste do pezinho e vacinação. 
Estas Unidades de Saúde são monitoradas e avaliadas por meio do Sistema de Informação da Atenção Básica-SIAB, conforme preconizado pelo Ministério da Saúde.

\subsection{Características do estudo}

O trabalho desenvolvido tem um caráter predominantemente exploratório, uma vez que este tipo de estudo consiste em "investigação de pesquisa empírica" cujo objetivo é a formulação de questões ou de um problema, com tripla finalidade: desenvolver hipóteses, aumentar a familiaridade do pesquisador com o ambiente, fato ou fenômeno, para a realização de uma pesquisa futura mais precisa ou modificar e clarificar conceitos (LAKATOS; MARCONI, 1985). Em um estudo exploratório, podem ser obtidas descrições tanto qualitativas quanto quantitativas.

A natureza das questões apontadas na construção do objeto de estudo e do quadro teórico sustentado pelos conceitos de estresse, riscos psicossociais no ambiente de trabalho que podem levar ao estresse, estratégias de gerenciamento, o modelo de assistência de saúde da família e o seu ambiente psicossocial, implicam em localizar esta investigação dentro da abordagem qualitativa.

A pesquisa qualitativa trata de características muito específicas em relação ao objeto de estudo.

Ela se preocupa, nas ciências sociais, com um nível de realidade que não pode ser quantificado. Ou seja, ela trabalha com o universo de significados, motivos, aspirações, crenças, valores e atitudes, o que corresponde a um espaço mais profundo das relações, dos processos e dos fenômenos que não podem ser reduzidos à operacionalização de variáveis. Não existe um continuum entre "qualitativo-quantitativo", em que o primeiro termo seria o lugar da "intuição", da exploração" e do "subjetivismo"; e o segundo representaria o espaço do científico, porque é traduzido "objetivamente" e em "dados matemáticos" (MINAYO, 1994, p.21-22) . 
Bogdan e Biklen (1999) afirmam que "o objetivo dos investigadores qualitativos é o de melhor compreender o comportamento e experiência humanos". Estes pesquisadores devem tentar compreender o processo mediante o qual as pessoas constroem significados, e descrever em que consistem estes mesmos significados. Recorrem à observação empírica, por considerarem que é em função de instâncias concretas do comportamento humano que se pode refletir com maior clareza e profundidade sobre a condição humana.

Para o tratamento dos dados de uma pesquisa qualitativa, vários autores reforçam a análise de conteúdo dos dados coletados.

\subsection{Sujeitos da pesquisa}

Os sujeitos do estudo trabalham em regime de turno fixo com jornada de 40 horas semanais, sendo oito horas diárias, no período de segunda a sexta-feira, com folgas aos finais de semana, exceto quando convocados para campanhas do Ministério da Saúde.

Os trabalhadores pertencem às equipes mínimas de Saúde da Família (composta por médico, enfermeiro, dentista, auxiliares de enfermagem e agentes comunitários de saúde), em cada Unidade de Saúde de Família mantida exclusivamente pelo município de Ribeirão Preto, Estado de São Paulo, qualificadas pelo SIAB-Municipal até agosto de 2004. Um trabalhador de cada categoria profissional foi entrevistado, conforme disponibilidade e interesse em participar do estudo.

Foram excluídos os trabalhadores da equipe de saúde bucal, devido a recente implantação (no ano de 2003), e assim, participaram da pesquisa 24 trabalhadores.

\subsection{Instrumento de coleta de dados}

Os dados foram coletados por meio de entrevistas semi-estruturadas, com o uso de um roteiro previamente elaborado, contendo questões norteadoras, mas 
deixando fluir a comunicação entre o entrevistador e entrevistado. O roteiro foi criado para proporcionar uma introdução ao tema durante a entrevista e atenção especial ao assunto considerado, evitando que a conversa extrapolasse para outros campos (Apêndice I).

A entrevista apresentou informações referentes às características dos profissionais como: idade, sexo, estado civil e função exercida no local de trabalho e também contou com cinco perguntas abertas relacionadas ao tema proposto. As questões foram direcionadas para o levantamento dos riscos presentes no trabalho e estratégias para o seu gerencimento.

Para Cruz Neto (1994), a entrevista é um processo muito usual no trabalho de campo. Através dela, o pesquisador busca obter informes contidos na fala dos atores sociais. Ela não significa uma conversa neutra, uma vez que se insere como meio de coleta dos fatos relatados pelos autores, enquanto sujeitos-objeto da pesquisa que vivenciam uma realidade que está sendo focalizada.

\subsection{Procedimentos de coleta de dados}

A coleta de dados ocorreu no período de 20 de janeiro a 10 de março de 2005.

A fim de atingir os objetivos deste estudo, a pesquisa foi realizada em dois momentos.

No primeiro momento, ocorreu a busca de documentos oficiais e/ou fontes de informações do município sobre a implantação do Programa de Saúde da Família, tais como: Projeto de Lei 660/94 publicado no Diário oficial de 07/11/95, Projeto de Lei n052/97 da Câmara Municipal de Ribeirão Preto, Site da Secretaria Municipal de Saúde de Ribeirão Preto para busca de características gerais do município, população e rede básica de atenção à saúde, Projeto de Implantação do Programa de Saúde da Família, através do Centro de Informação Digital em Saúde do município.

O segundo momento compreendeu a realização das entrevistas com o objetivo de levantar a percepção das Equipes de Saúde da Família acerca das características do seu ambiente de trabalho, possibilitando a identificação dos riscos 
psicossociais presentes e que podem levar ao estresse, além das estratégias para o seu gerencimento.

As entrevistas foram realizadas pelo pesquisador e ocorreram individualmente no horário de trabalho, conforme a disponibilidade do profissional. O local da entrevista era escolhido no momento da coleta, sendo na maioria das vezes, uma sala de consultório médico. As entrevistas foram gravadas após o consentimento dos entrevistados, tendo uma média de duração de 40 minutos.

Consideramos que a gravação tem a vantagem de registrar todas as expressões orais imediatamente, deixando o entrevistador livre para prestar toda a sua atenção no entrevistado (LUDKE ; ANDRÉ, 1986).

Os entrevistados foram informados sobre o sigilo de suas respostas e que poderiam interromper a entrevista a qualquer momento.

Após a realização de todas as entrevistas, foi realizada a transcrição dos dados pelo pesquisador.

A transcrição para o papel é considerada tarefa trabalhosa, consumindo muitas horas do entrevistador, onde as informações aparecem num todo mais ou menos indiferenciado, sendo necessário uma comparação desse material com a gravação, para se estabelecerem as prioridades, com o auxílio, é claro, da memória do entrevistador (LUDKE; ANDRÉ, 1986).

\subsection{Análise dos dados}

O corpus da análise foi composto pelos dados coletados através das entrevistas, complementadas com informações provenientes de fontes documentais (documentos jurídicos, legislação, Centro de Informação Digital em Saúde do município- CIDS) e do suporte teórico desta investigação.

A análise do presente estudo baseou-se na proposta de interpretação qualitativa, modalidade temática através do método de análise de conteúdo de Bardin (1977).

Minayo (1994) menciona que a análise de conteúdo é a expressão mais comumente usada para representar o tratamento dos dados de uma pesquisa qualitativa. 
Para Bardin (1977), a análise de conteúdo aparece como um conjunto de técnicas de análise das comunicações, que utiliza procedimentos sistemáticos e objetivos de descrição do conteúdo das mensagens e que o seu objetivo é a inferência de conhecimentos relativos às condições de produção com a ajuda de indicadores (quantitativos ou não).

A análise de conteúdo é como um trabalho de arqueólogo: trabalha sobre os traços dos documentos que ele pode encontrar ou suscitar, traços estes que são a manifestação de estados, dados, características ou fenômenos. Existe alguma coisa a descobrir sobre eles e o analista pode manipular estes dados por inferência de conhecimentos sobre o emissor da mensagem ou pelo conhecimento do assunto estudado, de forma a obter resultados significativos a partir dos dados. $O$ pesquisador trabalha explorando os dados como um detetive (BARDIN, 1977).

No conjunto das técnicas da análise de conteúdo, a análise por categorias é a mais utilizada e funciona por operações de desmembramento do texto em unidades, em categorias segundo reagrupamentos analógicos. As categorias fornecerão, então, os elementos necessários a uma análise conclusiva. A categorização tem como primeiro objetivo fornecer uma representação simplificada dos dados brutos.

Entre as diferentes possibilidades de categorização, a investigação dos temas, ou análise temática, é rápida e eficaz na condição de se aplicar a discursos diretos (significações manifestas) e simples (BARDIN, 1977).

A narrativa oriunda das entrevistas com o conjunto dos trabalhadores foi analisada segundo a análise temática.

Fazer uma análise temática consiste em descobrir os núcleos de sentido que compõem a comunicação e cuja presença, ou freqüência de aparição, podem significar alguma coisa para o objetivo analítico escolhido (BARDIN, 1977, p.105). Tradicionalmente, a análise temática encaminha-se para contagem de freqüência das unidades de significação como definitórias do caráter do discurso. Ou, ao contrário, qualitativamente, a presença de determinados temas denota os valores de referência e os modelos de comportamento presentes no discurso (MINAYO, 1994).

Operacionalmente a análise temática desdobra-se em três etapas, segundo Bardin (1977). São elas: pré-análise, exploração do material e tratamento dos resultados obtidos e interpretação. 
1ª) A pré-análise corresponde à fase de reorganização da pesquisa, onde são selecionados os documentos a serem analisados; revêem-se as hipóteses e os objetivos iniciais podendo, se necessário, diante dos dados coletados, reformulá-los. Ela também permite a elaboração de indicadores que orientem a interpretação final. Nesta fase, incluem-se as seguintes tarefas: a leitura flutuante, constituição do corpus de análise (composto pelos dados das entrevistas) e formulação de hipóteses e objetivos.

A leitura flutuante dos textos de comunicação processa-se através de leituras do material a ser analisado e conhecido, mantendo-se contato estreito com o texto, a fim de se familiarizar com seu conteúdo e poder imbuir-se de expressões e orientações. E a leitura flutuante vai se tornando mais definida em função do trabalho entre as hipóteses iniciais e as emergentes.

$\mathrm{Na}$ constituição do corpus de análise, faz-se a organização do conjunto dos documentos que serão submetidos à análise, de modo que estes possam responder a algumas regras: exaustividade (levar em conta todos os elementos obtidos do instrumento de coleta de dados); representatividade (que contenha a representação do universo pretendido); homogeneidade (obedecer a critérios precisos de escolha no que se refere a temas, técnicas e interlocutores) e pertinência (os documentos analisados, enquanto fonte de informação, devem ser adequados ao objetivo da pesquisa.

Em relação à formulação de hipóteses e dos objetivos, sabemos que a primeira é uma afirmação que pode ser confirmada ou revogada, após a verificação, através de procedimentos de análise; já o objetivo é a meta geral a que nos propomos a atingir e cujos resultados encontrados utilizaremos.

$\left.2^{a}\right)$ A exploração do material trata essencialmente de operações de codificação. Bardin (1977) relata que a codificação corresponde a uma transformação sistemática dos dados brutos do texto, por recorte, agregação e enumeração, visando a atingir uma representação do conteúdo ou da sua expressão e, conseqüentemente, a compreensão do texto.

A análise temática, nesta fase, trabalha primeiro com o recorte do texto, que é a escolha das unidades de registro, podendo estas serem uma palavra, uma frase, um tema, um personagem ou um acontecimento, como foi determinado na pré-análise. Em seguida, realiza-se a escolha das regras de contagem ou a enumeração. Posteriormente procede-se à classificação e à agregação dos dados, 
à escolha das categorias que podem ser teóricas ou empíricas comandando a especificação dos temas.

$3^{a}$ ) O tratamento dos dados obtidos e interpretação. Os resultados podem ser tratados tanto pela abordagem quantitativa quanto pela qualitativa, apesar de que ambas não têm o mesmo campo de ação. A abordagem qualitativa utiliza-se de um procedimento mais intuitivo, flexível e ajustável à evolução das hipóteses, caminho este percorrido neste estudo.

Nesse sentido, as discussões das unidades temáticas, depreendidas da análise do material coletado nas entrevistas, estão fundamentadas na identificação dos riscos do ambiente de trabalho e estratégias para o seu gerenciamento, possibilitando o agrupamento e a classificação das unidades temáticas em dois temas centrais, que são os "riscos psicossociais relacionados ao trabalho" e as "estratégias para o controle dos riscos psicossociais".

Lembramos que as unidades temáticas, relacionadas aos riscos psicossociais no trabalho, foram conceituadas tendo por base as "falas" dos entrevistados, bem como, nosso referencial teórico analítico de Cox et al., (2000).

\subsection{Considerações éticas}

O projeto de pesquisa foi submetido à Secretaria Municipal de Saúde do município de Ribeirão Preto a fim de solicitar a aprovação para a realização do estudo. Após o consentimento desta Secretaria, o Projeto foi encaminhado ao Comitê de Ética em Pesquisa da Escola de Enfermagem de Ribeirão Preto-USP.

A partir da aprovação do Comitê (ANEXO I), foi solicitada verbalmente a autorização aos gerentes das unidades selecionadas, para o início da coleta de dados.

Para cada sujeito da pesquisa, antes do início da coleta de dados, foi entregue um "Termo de Consentimento Livre e Esclarecido" de acordo com a Resolução do CNS 196/96 (Apêndice II). 
Após o consentimento de cada trabalhador em participar da pesquisa e da prévia autorização da instituição, realizamos as entrevistas propriamente ditas, individualmente, durante o período de trabalho destes profissionais.

O sigilo dos participantes foi mantido através da identificação das "falas" com a categoria profissional e algarismos de um a seis para as equipes, propostos aleatoriamente. 
5 RESULTADOS 


\subsection{O Programa de Saúde da Família e o cenário institucional da pesquisa}

A implantação do Programa de Saúde da Família no município de Ribeirão Preto foi autorizada através da Lei no 7229 de 24 de outubro de 1995. Seu Art. $1^{\circ}$ diz que "fica por esta lei, autorizado ao Poder Executivo a implantação no município, do "Programa de Saúde de Família-Médico de Família". O Art.2 diz que o Programa de Saúde da Família consistirá no desenvolvimento de atividades destinadas à saúde pública, com ênfase às posturas e medidas preventivas, nos bairros e conjuntos habitacionais do município em que o Poder Público não propicie esses serviços (CÂMARA MUNICIPAL RIBEIRÃO PRETO, 1995).

Em 1999, a Lei nº350 de 26 de março "dá nova redação ao artigo $2^{\circ}$ da Lei $n^{0} 7229 / 95$. $O$ art. $2^{\circ}$ passa a vigorar com a seguinte redação: O Programa de Saúde da Família- Médico de Família, consistirá no desenvolvimento de atividades destinadas à saúde pública, preferencialmente nas áreas de Clínica Médica, Ginecologia, Pediatria e Geriatria, com ênfase às posturas e medidas preventivas, nos bairros não atendidos por Unidade Básica de Saúde com tais programas (CÂMARA MUNICIPAL RIBEIRÃO PRETO, 1999).

O município de Ribeirão Preto, na busca de uma reorganização da atenção à saúde prestada aos seus munícipes, propõe a sua qualificação no PSF, com a inserção de Equipes de Saúde da Família. Este projeto de implantação do PSF teve como objetivo geral desenvolver atividades com vistas à melhoria do estado de saúde da população através de um modelo de assistência voltado para a família e à comunidade que incluiria desde a promoção e proteção à saúde até a identificação precoce e o tratamento de doenças. Para a implantação deste projeto, são propostos objetivos específicos como: adequação das unidades de saúde para melhorar a resolutividade da assistência prestada, garantindo a sua relação com os níveis de maior complexidade do Sistema, transformando-as em Unidades de Saúde da Família; a valorização da família e seu espaço social como núcleo prívilegiado de atenção do serviço de saúde; contribuir para a organização da comunidade para o exercicício efetivo da participação e controle social; garantir a intersetorialidade no município na busca de soluções para a melhoria da qualidade de vida da população; promover e garantir a educação permanente contínua dos 
profissionais envolvidos e melhorar o sistema de informação sobre a saúde da população.

Dentro da área de abrangência da Unidade de Saúde da Família (USF), uma subárea e sua população são vinculadas (adscritas) a uma equipe de saúde, que é responsável pelos serviços prestados à comunidade adscrita. Outras subáreas são de responsabilidade de outras equipes de saúde, cujo número é proporcional à população da área de abrangência da USF de origem.

Considerando que a mudança da forma de trabalho, do sistema tradicional para PSF, é tarefa difícil e somadas as características próprias de cada Unidade Básica de Saúde (UBS) já existente, a Secretaria Municipal da Saúde optou por implantar o novo modelo, segundo as regras seguintes (RIBEIRÃO PRETO, 2005):

1- Todas as novas Unidades de Saúde para nível primário de atendimento, que forem instaladas, serão USF, ou seja, equipes completas que trabalharão desde o início;

2- As antigas UBSs serão transformadas gradativamente em USFs; Durante um período de transição, essas Unidades de Saúde serão mistas, com a forma anterior de atendimento sendo substituída pelo PSF;

3- No caso do item anterior, as equipes começarão com os Agentes Comunitários de Saúde (ACS) e serão completados numa velocidade que dependerá de cada UBS.

Em outubro de 2000, o município foi qualificado para o desenvolvimento do Programa de Saúde da Família, sendo habilitadas inicialmente 5 equipes ligadas à Universidade de São Paulo através do convênio entre esta Universidade, governo do Estado e Secretaria Municipal de Saúde. Dessa forma, em 2001 foram implantados cinco núcleos de Saúde da Família ligados à Universidade, e à partir de 2002 foram somadas a esta rede pública outras Equipes de Saúde da Família, perfazendo em janeiro de 2005, um total de 18 equipes, cinco ligadas à Universidade e nove de responsabilidade exclusiva do município. Estas nove equipes situam-se em seis Unidades de Saúde as quais representam o nosso local de estudo.

Para assumir a estratégia Saúde da Família em todo o município, propõese uma redistribuição quantitativa dos recursos humanos, de acordo com as áreas ou abrangência das Unidades de Saúde, conforme mostra o Quadro 2 . 
Quadro 2 - Distribuição da previsão de recursos humanos, segundo a área de abrangência das Unidades Básicas de Saúde. Ribeirão Preto, 2004

\begin{tabular}{|c|c|c|c|c|c|c|c|c|c|}
\hline \multirow[b]{2}{*}{ Unidades } & \multirow[b]{2}{*}{ População } & \multirow[b]{2}{*}{ ACS } & \multirow[b]{2}{*}{ ESF } & \multirow[b]{2}{*}{ Enf. } & \multirow[b]{2}{*}{ Méd. } & \multirow[b]{2}{*}{$C D$} & \multirow[b]{2}{*}{ ACD } & \multicolumn{2}{|c|}{$\mathrm{Tec} / \mathrm{Au}$} \\
\hline & & & & & & & & $x$ Enf & Cobertura $(\%)$ \\
\hline UBDS Central e PAM II & 64327 & 86 & 17 & 17 & 17 & 9 & 9 & 34 & 10,5 \\
\hline UBS Materno-Infantil & 39300 & 52 & 9 & 9 & 9 & 5 & 5 & 18 & 5,4 \\
\hline UBS e CSE Vila Tibério & 17924 & 24 & 4 & 4 & 4 & 2 & 2 & 8 & 2,5 \\
\hline UBS Bonfim Paulista & 10157 & 18 & 3 & 3 & 3 & 2 & 2 & 6 & 1,9 \\
\hline UBDS Vila Virgínia & 40797 & 54 & 9 & 9 & 9 & 5 & 5 & 18 & 5,6 \\
\hline UBS Parque Ribeirão & 33100 & 44 & 8 & 8 & 8 & 4 & 4 & 16 & 4,9 \\
\hline UBS Adão do Carmo & 8394 & 11 & 2 & 2 & 2 & 1 & 1 & 4 & 1,2 \\
\hline UBS Jd Maria das Graças & 7961 & 16 & 3 & 3 & 3 & 2 & 2 & 6 & 1,9 \\
\hline UBDS Castelo Branco & 50703 & 68 & 12 & 12 & 12 & 6 & 6 & 24 & 7,4 \\
\hline UBS Santa Cruz & 18601 & 25 & 5 & 5 & 5 & 3 & 3 & 10 & 3,1 \\
\hline UBS Jardim Zara & 8255 & 11 & 2 & 2 & 2 & 1 & 1 & 4 & 1,1 \\
\hline UBS Vila Abranches & 8633 & 12 & 2 & 2 & 2 & 1 & 1 & 4 & 1,2 \\
\hline UBS Jardim Juliana & 6299 & 9 & 2 & 2 & 2 & 1 & 1 & 4 & 1,2 \\
\hline UBS São José & 8217 & 11 & 2 & 2 & 2 & 1 & 1 & 4 & 1,1 \\
\hline UBDS Simioni & 19416 & 26 & 5 & 5 & 5 & 3 & 3 & 10 & 3,1 \\
\hline UBS Marincek & 21457 & 33 & 6 & 6 & 6 & 3 & 3 & 12 & 3,7 \\
\hline UBS Valentina Figueiredo & 3858 & 6 & 1 & 1 & 1 & 1 & 1 & 2 & 0,5 \\
\hline UBS Quintino Facci I & 14881 & 20 & 4 & 4 & 4 & 2 & 2 & 8 & 2,5 \\
\hline UBS Quintino Facci II & 22304 & 30 & 5 & 5 & 5 & 3 & 3 & 10 & 3,1 \\
\hline UBS Vila Mariana & 13352 & 25 & 5 & 5 & 5 & 3 & 3 & 10 & 3,1 \\
\hline UBS e CSE Ipiranga & 20349 & 27 & 5 & 5 & 5 & 3 & 3 & 10 & 2,8 \\
\hline UBS Dom Mielle & 9958 & 18 & 3 & 3 & 3 & 2 & 2 & 6 & 1,9 \\
\hline UBS José Sampaio & 15193 & 20 & 4 & 4 & 4 & 2 & 2 & 8 & 2,5 \\
\hline UBS Maria Casa Grande & 7819 & 16 & 3 & 3 & 3 & 2 & 2 & 6 & 1,9 \\
\hline UBS Vila Albertina & 22168 & 30 & 5 & 5 & 5 & 3 & 3 & 10 & 3,0 \\
\hline UBS Vila Recreio & 21371 & 28 & 5 & 5 & 5 & 3 & 3 & 10 & 2,9 \\
\hline UBS Presidente Dutra & 6465 & 10 & 2 & 2 & 2 & 1 & 1 & 4 & 1,2 \\
\hline CMSC Vila Lobato & 18273 & 24 & 4 & 4 & 4 & 2 & 2 & 8 & 2,5 \\
\hline UBDS Sumarezinho & 19430 & 26 & 5 & 5 & 5 & 3 & 3 & 10 & 3,1 \\
\hline Total & 558963 & 780 & 142 & 142 & 142 & 79 & 79 & 284 & 86,6 \\
\hline
\end{tabular}

Fonte: CIDS. Centro de Informação Digital em Saúde. Caracterização dos profissionais das Equipes de Saúde da Família [mensagem pessoal]. Mensagem recebida por jscamelo@uol.com.br em 22 de out. 2004. 
Verificamos no quadro anterior que a distribuição do número de recursos humanos varia de acordo com o número populacional. Conforme a preconização do Ministério da Saúde é necessária, pelo menos, uma equipe mínima de Saúde da Família para assistir no máximo 1.000 famílias ou 4.500 pessoas, ou seja, um médico, um enfermeiro, dois auxiliares ou técnicos de enfermagem e quatro a seis agentes comunitários de saúde. Os agentes comunitários de saúde são calculados como um para 150 famílias ou 750 pessoas (Brasil, 1998).

No ano de 2000, o MS propõe que sejam incorporados às equipes um odontólogo e um atendente de consultório dentário (SILVA;TRAD, 2005).

Assim, o dimensionamento de pessoal para compor as Equipes de Saúde da Família é calculado com base na preconização do Ministério da Saúde, e não considerando a complexidade das necessidades da área de abrangência.

Cada Equipe de Saúde da Família é composta, de modo geral, por: um médico clínico, um pediatra, um médico ginecologista, um cirurgião dentista, um enfermeiro, dois auxiliares de enfermagem, cinco agentes comunitários de saúde.

A cobertura das áreas pelo Programa de Saúde da Família, do município, em janeiro de 2005, está presente em 3 Distritos de Saúde, como descrevemos a seguir:

\section{UBDS Sumarezinho- Distrito Oeste}

- Quatro Núcleos de Saúde da Família, onde atuam conjuntamente SMS, Faculdade de Medicina de Ribeirão Preto-USP, Escola de Enfermagem- USP e FAEPA;

- Duas Equipes de Saúde da Família na Unidade de Saúde D.Miele;

- Duas Equipes de Saúde da Família na Unidade de Saúde do Maria Casagrande Lopes;

- Duas Equipes de Saúde da Família na Unidade de Saúde da Vila Recreio;

- Uma Equipe de Saúde da Família na Unidade de Saúde do Presidente Dutra. 


\section{UBDS Distrital Norte}

- Duas Equipes de Saúde da Família na Unidade de Saúde do Jardim Heitor Rigon;

- Uma Equipe de Saúde da Família na Unidade de Saúde do Marincek.

- Três Equipes de Saúde da Família na Unidade de Saúde da Família do Ribeirão Verde.

\section{Distrito Central}

- Um núcleo de Saúde da Família, onde atuam conjuntamente SMS, Faculdade de Medicina de Ribeirão Preto-USP, Escola de Enfermagem- USP e FAEPA, inserido na Unidade Básica de Saúde da Vila Tibério.

A população do município de Ribeirão Preto coberta pela estratégia de Saúde da Família, em janeiro de 2005, é de 188.391 habitantes e 50.729 famílias, o que corresponde a $34,7 \%$ da população e $9,3 \%$ de famílias. A distribuição de recursos humanos de todas as equipes de Saúde da Família, do município, está representada no Quadro 3.

A Secretaria Municipal de Saúde (SMS) propõe que toda a atenção primária à saúde, em Ribeirão Preto, seja desenvolvida segundo modelo de assistência do PSF. 
Quadro 3- Distribuição dos Recursos Humanos das Equipes de Saúde da Família por categoria profissional, Ribeirão Preto, 2005.

\begin{tabular}{|l|l|l|l|c|c|c|}
\hline $\begin{array}{l}\text { Unidade de } \\
\text { Saúde }\end{array}$ & ACS & Enfermeiro & $\begin{array}{l}\text { Médico } \\
\text { Generalista }\end{array}$ & $\begin{array}{l}\text { Auxiliar } \\
\text { Enfermagem }\end{array}$ & $\begin{array}{l}\text { Cirurgião } \\
\text { Dentista }\end{array}$ & ACD \\
\hline Núcleo 1 & 04 & 01 & 01 & 02 & & \\
\hline Núcleo 2 & 04 & 01 & 01 & 02 & & \\
\hline Núcleo 3 & 04 & 01 & 01 & 02 & & \\
\hline Núcleo 4 & 04 & 01 & 01 & 02 & & \\
\hline Núcleo 5 & 04 & 01 & 01 & 02 & 01 & 01 \\
\hline Eq.1 D. Miele & 06 & 01 & 01 & 02 & 01 & 01 \\
\hline Eq.2 D. Miele & 06 & 01 & 01 & 02 & 01 & 01 \\
\hline $\begin{array}{l}\text { Eq.1Maria } \\
\text { Casagrande }\end{array}$ & 05 & 01 & 01 & 02 & 01 & 01 \\
\hline $\begin{array}{l}\text { Eq 2 Maria } \\
\text { Casagrande }\end{array}$ & 06 & 01 & 01 & 02 & 01 & 01 \\
\hline Eq1 V. Recreio & 06 & 01 & 01 & 01 & 01 \\
\hline Eq.2V. Recreio & 06 & 01 & 01 & 01 & 02 & 01 \\
\hline $\begin{array}{l}\text { Equipe PSF } \\
\text { J. P.Dutra }\end{array}$ & 06 & 01 & 01 & 01 & 01 & 01 \\
\hline $\begin{array}{l}\text { Equipe 1 } \\
\text { Heitor Rigon }\end{array}$ & 04 & 01 & 01 & 01 & 01 \\
\hline $\begin{array}{l}\text { Equipe 2 } \\
\text { Heitor Rigon }\end{array}$ & 04 & 01 & 01 & 01 & 01 \\
\hline $\begin{array}{l}\text { Equipe PSF } \\
\text { Marincek }\end{array}$ & 06 & 01 & 01 & 02 & 01 \\
\hline $\begin{array}{l}\text { Equipe 1 } \\
\text { Rib.Verd }\end{array}$ & 06 & 01 & 01 & 01 & 01 & 01 \\
\hline $\begin{array}{l}\text { Equipe 2 } \\
\text { Rib.Verd }\end{array}$ & 06 & 01 & 01 & 01 & 01 & 01 \\
\hline Eq3 Rib.Verd & 06 & 01 & 01 & 02 & 01 & \\
\hline
\end{tabular}

Fonte: Ribeirão Preto. Secretaria Municipal de Saúde. Plano de Saúde de Ribeirão Preto. SUS. Período 2005-2008. Disponível em www.coderp.com.br/saude/i16principal.asp?pagina=/ssaude/ principal/ painel/ 116indice.htm. Acesso em dezembro de 2005.

Os enfermeiros das equipes estão vinculados às $U_{B S}$ que serão as Unidades de Referência no Programa.

A Secretaria Municipal da Saúde participa, através do Pólo Norte/Oeste de Capacitação, de um processo educativo para capacitar os profissionais que aderiram ao PSF do município de Ribeirão Preto. 


\subsection{Perfil dos sujeitos da pesquisa}

Os trabalhadores que compuseram o grupo de entrevistados desta investigação pertenciam a seis equipes de Saúde da Família, tendo estas vínculo exclusivo com a Secretaria Municipal da Saúde de Ribeirão Preto.

A distribuição espacial dos trabalhadores das Equipes de Saúde da Família das Unidades de Saúde pertencentes a este estudo, no momento da coleta de dados, são demonstradas no Quadro 4 .

Quadro 4- Distribuição dos trabalhadores das Equipes de Saúde da Família, segundo as suas Unidades Básicas de Saúde e categoria profissional. Ribeirão Preto, 2005.

\begin{tabular}{|l|c|c|c|c|c|}
\hline \multirow{2}{*}{$\begin{array}{l}\text { Unidades } \\
\text { de } \\
\text { Saúde }\end{array}$} & \multicolumn{5}{|l|}{ Profissionais das equipes de Saúde da Família } \\
\cline { 2 - 6 } & Médico & Enfermeiro & $\begin{array}{l}\text { Auxiliar } \\
\text { Enfermagem }\end{array}$ & $\begin{array}{l}\text { Agente } \\
\text { comunitário }\end{array}$ & TOTAL \\
\hline $\begin{array}{l}\text { Aymar Batista } \\
\text { Prado(D. Miele) }\end{array}$ & 2 & 2 & 4 & 10 & 18 \\
\hline $\begin{array}{l}\text { Sérgio B. Costa } \\
\text { (Pres. Dutra) }\end{array}$ & 1 & 1 & 2 & 6 & 10 \\
\hline $\begin{array}{l}\text { Ern. Guevara } \\
\text { M. Casagrande }\end{array}$ & 2 & 2 & 4 & 11 & 19 \\
\hline $\begin{array}{l}\text { Adalberto Andrade } \\
\text { N. Recreio) }\end{array}$ & 2 & 2 & 2 & 12 & 18 \\
\hline $\begin{array}{l}\text { Aberto Sabin } \\
\text { (Marincek) }\end{array}$ & 1 & 1 & 2 & 6 & 10 \\
\hline $\begin{array}{l}\text { Heitor } \\
\text { Higon }\end{array}$ & 2 & 2 & 3 & 10 & 17 \\
\hline Total & 10 & 10 & 17 & 55 & 92 \\
\hline
\end{tabular}

O Quadro 4 mostra a realidade encontrada no momento da coleta de dados. Se compararmos com o Quadro anterior (3) podemos verificar algumas diferenças com relação ao número de trabalhadores das categorias profissionais auxiliares de enfermagem e agentes comunitários de saúde, sendo que, no momento da coleta havia um número menor de agentes comunitários de saúde na Unidade Aymar Batista Prado (D. Miele), significando a saída destes trabalhadores. Já em relação a Unidade Heitor Rigon verifica-se um número maior de auxiliar de enfermagem e agentes comnitários de saúde.

Neste estudo, foram incluídos seis trabalhadores de cada categoria profissional, totalizando 24 sujeitos das unidades representadas acima. 
Para a apresentação dos resultados quanto à caracterização dos sujeitos, consideramos as variáveis de identificação dos profissionais como sexo, idade, estado civil e categoria profissional, conforme apresentado no Quadro 5.

Quadro 5- Distribuição dos trabalhadores pertencentes às Equipes de Saúde da Família, segundo sexo, idade e categoria profissional. Ribeirão Preto, 2005.

\begin{tabular}{|c|c|c|c|c|c|c|c|c|c|}
\hline \multirow[t]{2}{*}{ SEXO } & \multicolumn{4}{|c|}{ FEMININO } & & \multicolumn{2}{|c|}{ MASCULINO } & \multicolumn{2}{|c|}{ TOTAL } \\
\hline & \multicolumn{4}{|c|}{$\mathrm{N}$} & $\%$ & $\mathrm{~N}$ & $\%$ & $\mathrm{~N}$ & $\%$ \\
\hline Profis. & Méd & Enf & $\begin{array}{l}\text { Aux } \\
\text { Enf }\end{array}$ & ACS & & Méd & & & \\
\hline $35-40$ & - & - & 2 & 2 & 16,6 & 1 & 4,2 & 5 & 20,8 \\
\hline $40 \quad-45$ & 1 & 3 & 2 & 1 & 29,1 & 1 & 4,2 & 8 & 33,3 \\
\hline $45 \mathrm{I}-50$ & 1 & 2 & 1 & 2 & 25,0 & 1 & 4,2 & 7 & 29,2 \\
\hline $50-56$ & 1 & 1 & 1 & 1 & 16,6 & - & - & 4 & 16,7 \\
\hline Total & 3 & 6 & 6 & 6 & 87,5 & 3 & 12,5 & 24 & 100 \\
\hline
\end{tabular}

De acordo com os dados do Quadro 5, a configuração das equipes é predominantemente feminina $(87,5 \%)$, sendo esta situação mais evidente para os trabalhadores de enfermagem e de nível médio (auxiliares de enfermagem, enfermeiros e agentes comunitários de saúde). Esta situação se confirma quando Machado (2000) relata que, o Programa de Saúde da Família absorve mais mulheres em suas equipes de trabalho. Quanto a enfermagem, observa-se que $100 \%$ destes profissionais são do sexo feminino, não fugindo a caracterização peculiar dessa profissão.

Entre os trabalhadores de nível universitário de nosso estudo, embora haja predomínio do sexo feminino, há presença masculina $(50 \%)$ entre os médicos. Segundo dados de uma pesquisa sobre médicos no Brasil (MACHADO et al., 1997 apud MACHADO, 2000, p.29) ${ }^{1}$, a medicina é uma profissão predominantemente masculina, $67,3 \%$ dos médicos no Brasil são homens e $32,7 \%$ são mulheres. No PSF, a relação entre os profissionais feminino e masculino, na medicina, é mais equilibrada, 44,05\% dos médicos no Programa são mulheres. Este perfil se

\footnotetext{
${ }^{1}$ MACHADO, M.H. Perfil dos médicos e enfermeiros do Programa de Saúde da Família no Brasil: relatório final. Brasília: Ministério da Saúde, 2000.
} 
aproxima ao encontrado na pesquisa de Mishima (2003) realizada em três Equipes de Saúde da Família, onde há presença masculina em 33,3\% dos trabalhadores entrevistados, de nível universitário. Também devemos citar a pesquisa do Ministério da Saúde (BRASIL, 2002) em 10 grandes centros urbanos, onde esta situação é similar, mesmo levando-se em conta as diferenças regionais existentes.

Quando se olha para o perfil etário dos trabalhadores entrevistados, verifica-se que todos os trabalhadores se concentram na faixa etária entre 35 e 56 anos, apontando para uma equipe que provavelmente teve oportunidade de vivenciar outras experiências profissionais e pessoais diversas, o que pode contribuir para um melhor desempenho no trabalho junto à Equipe de Saúde da Família. Esta situação se aproxima da pesquisa de Machado (2000) onde apresenta uma alta concentração de profissionais na faixa etária entre 30 a 49 anos.

Este perfil diferencia-se daquele verificado na avaliação realizada pelo Ministério da Saúde (Brasil, 2002, p.144), onde se verificou que as Equipes de Saúde da Família pesquisadas apresentam como um traço característico, a distribuição dos trabalhadores em duas faixas etárias "-até 30 anos e acima de 45 anos. Entre os agentes comunitários de saúde (ACS) predomina a juventude [...]", sendo que em alguns dos centros urbanos, mais de $60 \%$ dos ACS têm até 30 anos de idade, o que não é identificado para as equipes entrevistadas nesta pesquisa, em Ribeirão Preto, visto que todos os trabalhadores têm mais de 35 anos.

Em relação ao estado civil, $16(66 \%)$ dos sujeitos são casados, cinco $(20,8 \%)$, solteiros e quatro ( $12,5 \%)$ divorciados.

Ao verificarmos que a maior parte dos trabalhadores de nossa pesquisa é casada, pode-se configurar um aumento do número de tarefas e responsabilidades. Este trabalhador deverá conciliar o trabalho e a família, de maneira que nenhuma das partes fique prejudicada.

\subsection{Os riscos psicossociais relacionados ao trabalho}

No âmbito do trabalho das Equipes de Saúde da Família vimos que são atribuídas atividades específicas para cada categoria profissional. 
Os trabalhadores da área da saúde, especificamente médicos, enfermeiros, auxiliares de enfermagem e agentes comunitários de saúde, pelas características do seu trabalho, como o contato próximo à comunidade e a exposição a uma realidade diversa e complexa, estão constantemente em presença de riscos no ambiente de trabalho.

A análise dos discursos identificou a presença de riscos psicossociais relacionados no trabalho e, então, foram construídas unidades temáticas relacionadas a eles, bem como, identificada a freqüência de sua presença nos discursos de cada profissional, conforme Quadro 6.

Quadro 6 - Distribuição das unidades temáticas relacionadas aos riscos psicossociais no trabalho das Equipes de Saúde da Família, segundo a sua freqüência em cada categoria profissional. Ribeirão Preto, 2005.

Unidades
Temáticas
Formação
Profissional
Função na
Instituição
Carga e
Esquema de
Trabalho
Relacionamento
Interpessoal
no Trabalho
Relação
Trabalho/ Família
Recursos
da
Unidade

\begin{tabular}{|c|c|c|c|c|c|}
\hline $\begin{array}{l}\text { Risco } \\
\text { Psicossocial }\end{array}$ & Méd. & Enf & $\begin{array}{l}\text { Auxil. } \\
\text { Enf. }\end{array}$ & ACS & Total \\
\hline $\begin{array}{l}\text { Falta de preparo e } \\
\text { capacitação }\end{array}$ & 6 & 6 & 6 & 6 & 24 \\
\hline Sobrecarga de papéis & 6 & 6 & 6 & 1 & 19 \\
\hline Longas horas de Trabalho & 6 & 6 & 6 & 6 & 24 \\
\hline $\begin{array}{l}\text { Conflito no trabalho em } \\
\text { equipe }\end{array}$ & 5 & 4 & 5 & 5 & 19 \\
\hline Dificuldade para conciliar & & & & & \\
\hline $\begin{array}{l}\text { Trabalho e família } \\
\text { Recursos materiais }\end{array}$ & 6 & 5 & 4 & 5 & 20 \\
\hline $\begin{array}{l}\text { Insuficientes } \\
\text { Recursos humanos }\end{array}$ & 5 & 4 & 3 & 6 & 18 \\
\hline Precários & 6 & 4 & 3 & 4 & 17 \\
\hline
\end{tabular}

Considerando o número de sujeitos de nossa pesquisa e de acordo com o Quadro 6, observamos que 100\% dos trabalhadores expressam em seus discursos o aspecto da "Formação profissional", bem como a "Carga e o esquema de trabalho". Os demais riscos psicossociais aparecem nas "falas" de mais de $50 \%$ dos profisssionais e serão discutidos no decorrer de cada unidade temática.

Para melhor compreensão dos riscos psicossociais encontrados, foram extraídas expressões ou frases dos discursos dos trabalhadores, e que os representam em cada unidade temática, as quais passaremos a descrever. 
Formação profissional : "Eu não fui preparado ...eu não tive capacitação" (MÉDEquipe 1)

Muitas transformações têm ocorrido no mundo do trabalho, entre as quais estão as referentes à tecnologia, aos estilos de gestão organizacional e ao crescimento da importância do setor de serviços no cenário econômico (BORGES et al., 2002). Com isso, constroem-se novas formas de organizar o trabalho e de relações do ser humano com o mesmo. Surgem cargos com atribuições mais variadas e mais complexas, mais responsabilidades e maior atenção à relação do trabalhador com o usuário, gerando novas exigências de qualidade na execução das tarefas, mais qualificação e novas competências do trabalhador.

As transformações do mundo do trabalho concretizam-se no setor de prestação de serviços de saúde pública, através da constante necessidade de adaptação dos trabalhadores às diversas e complexas situações presentes na realidade sanitária, que por sua vez, podem desencadear o estresse profissional.

As instituições prestadoras de serviços de saúde devem ter seus objetivos definidos e os trabalhadores preparados para atuarem nas atividades que lhes competem.

Para uma melhor qualidade na assistência diante das mudanças que vêm ocorrendo no setor da saúde, que exigem hoje, inclusive, um atendimento mais humanizado, é necessário que as instituições se preocupem com a capacitação de seus profissionais.

O profissional da Equipe de Saúde da Família, segundo normas do Ministério da Saúde, precisa ser capaz de atuar com criatividade e senso crítico, mediante uma prática competente que envolva ações de promoção, prevenção, recuperação e reabilitação. Deve ser capaz de planejar, organizar, desenvolver e avaliar ações articulando os diversos setores envolvidos na promoção da saúde (BRASIL, 1998).

Assim, este trabalhador é o elemento-chave para que o Programa de Saúde da Família se concretize, e desta forma, é imprescindível tornar este profissional satisfeito, motivado e capacitado, com a finalidade de melhorar o seu desenvolvimento profissional. 
À medida que se focaliza a relação com o usuário e novas competências do trabalhador, a tendência é necessitar da criatividade, da capacidade reflexiva do próprio trabalhador, do seu efetivo envolvimento e, em última análise, de sua própria saúde.

A falta de capacitação e preparo para atuar no Programa de Saúde da Família foi um dos riscos abordados por todos os profissionais das equipes entrevistadas. Assim, podemos dizer que estes trabalhadores consideram a formação profissional um aspecto importante para a prestação da assistência, neste Programa.

Para Cox et al. (2000), a formação e o preparo são riscos psicossociais incluídos em uma categoria a qual denominou por "Cultura e função Organizacional" e relacionada ao contexto do trabalho, que podem levar ao estresse profissional.

"Olha, eu não fui preparado. Eu trabalhava num posto comum..[...] Houve a necessidade de mais um médico aqui e então eu fui convidado[...] Eu não tive capacitação. [...] até o momento eu não tive incentivo para estar fazendo cursos, a não ser alguns cursos esporádicos.[...] Tem algum curso esporadicamente"(MÉD Equipe1).

"[...] Depois que eu comecei nós tivemos um Pólo. que eles chamaram de Pólo... antes da gente entrar....teve um curso para gente ter noções gerais do que era o Programa de Saúde da Família e do que nós faríamos aqui [...] E depois junto com o trabalho nós tínhamos um curso, às vezes 1 por semana" (MÉD - Equipe 2).

"[...] A gente foi convidada para trabalhar nessa equipe. Eu tinha que montar a equipe...tinha que ter os profissionais: médico, enfermeira, técnico ou auxiliar e agente comunitário de saúde. [...] e aí o negócio foi de aceitação e não aceitação. Não teve curso de preparo não... a gente só fazia reunião..." (AUX- Equipe 6)

De acordo com os entrevistados, o preparo oferecido pela instituição prestadora de serviços de saúde foi precário, ou seja, alguns cursos, reuniões e/ou encontros sem profundidade no modelo de assistência implantado.

A implementação do PSF, com a redefinição de competências daí decorrentes, associada ao desenvolvimento de novas tecnologias assistênciais ao atendimento (AIDS, Saúde Mental, etc.), induz à ampliação do escopo de prática das profissões (SEIXAS, 2002). 
O Programa de Saúde da Família é uma estratégia do Ministério da Saúde (no Brasil, implantado em 1994) que exige um processo de formação e capacitação permanente de todos os profissionais envolvidos, pois como assinalam Campos \& Belisário, "há uma carência de profissionais em termos quantitativos e qualitativos" que possam responder a este modelo de assistência à saúde (ALMEIDA; MISHIMA, 2001). As instituições têm papel fundamental na capacitação contínua de seus trabalhadores.

Esta capacitação deve proporcionar um instrumental para lidar com as questões técnicas, sociais, bem como emocionais.

A falta de capacitação e preparo é novamente apontada por outro trabalhador, quando fala sobre as características que um profissional deve apresentar para atuar no Programa de Saúde da Família.

"[...] De um dia para o outro eu comecei a trabalhar como médica do Programa de Saúde da Família. Eu estou acostumada a dizer pro médico que era nosso coordenador que...eu dormi pediatra e acordei médica da saúde da família, tendo de exercer o supermédico, né? porque eu acho que é um supermédico você dá conta de fazer pediatria, ginecologia, clínica, e eu tive a minha formação em pediatria. Foi dito para gente que faríamos cursos...eu achei que a gente fosse fazer uma reciclagem, falei: tudo bem, né, a gente precisa fazer... porque é diferente você sair da faculdade, tudo muito fresquinho na sua cabeça, você tem noções de tudo, do que você ficar 15 anos fazendo pediatria e depois fazer isso.[...] então quando me ofereceram o PSF eu fiquei entusiasmada...e foi me dito que a gente faria reciclagem e tal: Olha... não fizemos, só fizemos aquele curso introdutório que é assim mais pra gente aprender a trabalhar em equipe" (MÉD- Equipe 1)

Percebe-se a necessidade de um profissional com determinado perfil para o trabalho de saúde da família, que não centre apenas na formação clínica específica, mas na possibilidade de se dirigir à atenção ao indivíduo como um todo, para além do recorte do seu corpo ou órgão, mas também para o espaço físico, social e afetivo das famílias assistidas.

Em abrangente avaliação das escolas médicas pela Comissão Interinstitucional Nacional de Avaliação de Escolas Médicas (CINAEM) na década de 1990, verificou-se a inadequação do modelo pedagógico dominante para a formação de profissional adequado às reais necessidades de saúde da população brasileira. Esse modelo, hospitalocêntrico, isola o aluno do mercado de trabalho; 
oferece formação tecnocêntrica, em prejuízo da formação humanística; e baixa integração interdisciplinar. O ensino é centrado no professor, com ênfase nas ações terciárias e voltado à superespecialização. A formação, portanto, não é terminal (STELLA, 2002).

Os Ministérios da Saúde e Educação vêm elaborando políticas destinadas a promover mudanças na formação e distribuição dos profissionais de saúde: Diretrizes Curriculares Nacionais dos Cursos de Graduação da Área de Saúde, Programa de Incentivo às Mudanças Curriculares nos Cursos de MedicinaPROMED, Programa Nacional de Reorientação da Formação Profissioal em SáudePró-Saúde, Pólos de Capacitação de Saúde da Família, Programas de Residência Médica e Programa de Interiorização do Trabalho em Saúde - PITS.

A edição das novas Diretrizes Curriculares dos cursos da área da saúde pelo MEC em 2001 ( BRASIL, 2001) busca corrigir as deficiências na formação dos profissionais de saúde, eliminando a ênfase nas especializações e procurando formar um novo ator social: o profissional com formação generalista, direcionado primordialmente à atenção básica de saúde e capaz de resolver a maior parte dos problemas de uma população ainda carente do básico para a sua sobrevivência (SANTOS; CUTOLO, 2003).

A formação de recursos humanos na área da saúde deve acontecer em consonância com as diretrizes de uma política nacional de saúde, dentro de um modelo que integre a técnica, a competência, a integridade e resolutividade.

A situação de despreparo, para atuação no Programa de Saúde da Família, é expressa pelos trabalhadores em vários momentos, indicando a necessidade de busca de capacitação constante para este trabalho.

"[...] A gente caiu meio que de pára-quedas. Eu fui convidada a entrar numa equipe, mas o convite não falava o que era... Aí eu falei que não aceitava... Passado um mês, eu fiquei sabendo por outra pessoa que tinha aceitado... e aí eles foram me comunicar que seria para participar do PSF. Depois eu fui convidada novamente...e eu já aceitei porque eu achei que ia ser um negócio interessante. Mas eu não tinha conhecimento nenhum do que era o Programa de Saúde da Família, e acabei descobrindo aos poucos...eu não fiz cursos" (ENF-Equipe 3)

"Não tive preparo não... Nós só tivemos um curso, né, um curso lá na USP, na Escola de Enfermagem. [...] foi mais cursos com enfermeiras e médicos. Eu acho que sempre deve continuar tendo, é importante a gente aprender. Eu acho que precisa de mais... A gente nunca está bem preparada, precisa de mais..."(AUXEquipe 4) 
"Nós tivemos um pólo de capacitação durante uma semana o dia todo... foi depois do início das atividades[...] A gente começou sem preparo, a gente tinha mais ou menos uma noção do que seria... mas nós começamos sem preparo, tanto para fazer as divisões das microáreas...Então esse preparo foi depois, a gente tinha feito assim, sem.. Eu acho que seria importante a gente estar fazendo mais cursos, se aperfeiçoando mais.(ENF-Equipe 6)."

De acordo com os entrevistados, a seleção dos trabalhadores para atuarem no PSF não seguiu critérios específicos por parte da Secretaria Municipal de Saúde (SMS), além da consulta prévia se havia interesse e disponibilidade em dobrar a carga horária.

O PSF pretende reafirmar os princípios do SUS, e por isso fundamenta-se na concepção de atenção focalizada na promoção da qualidade de vida e tem como objetivo trabalhar práticas de saúde que gerem integração entre as ações individuais e coletivas.

Os pressupostos que devem nortear a organização das práticas de saúde voltadas às famílias, tais como a prestação de atenção integral, humanização e participação comunitária, são parte de uma estratégia para induzir mudanças pela reestruturação do processo de trabalho (VASCONCELOS, 1999). desenvolvimento dessas práticas obriga que os profissionais envolvidos na mesma tenham visão integral do sujeito, da família e da comunidade, e para tal é necessária a sua educação permanente.

Para a maioria dos trabalhadores entrevistados, a Saúde da Família era uma grande interrogação e não estavam claras as atividades que seriam realizadas por cada um. A falta de informação para desenvolver as atividades, e a ansiedade frente ao desconhecido, geraram insegurança em alguns trabalhadores, como podemos verificar a seguir.

"Eu moro na comunidade. Então eles jogaram a gente assim aí dentro, e falaram: vocês vão ser agente comunitário e tal... Nós ficamos perdidas, no começo, porque a gente não sabia nem o que era o Programa de Saúde da Família. Aí aos poucos a gente foi.......] mas preparo mesmo, a gente não teve.. Eu acho que ninguém se prepara em uma semana..."(ACS- Equipe 4) 
"Quando me perguntaram se eu queria trabalhar, eu não tinha nenhum preparo. Eu tinha ouvido alguma coisa em reportagem, mas eu não sabia como ia ser aqui e que tipo de coisa ia ser implantada.[...] Nenhum preparo, isso para mim gerou muita ansiedade". (MED -Equipe 4)

"Desgasta... a falta de preparo...isso pode ser desgastante na hora de lidar com a população...muito" (AUX -Equipe 3)

"Inicialmente foi muito angustiante porque me convidaram, me falaram que eu tinha o perfil para fazer parte do PSF, e tal... Então no começo você leva um susto, principalmente por estar 10 anos fora da Faculdade, exercendo uma especialidade... depois ter que lidar com o todo. Aí você fica apreensivo.[...] A minha formação básica é de ginecologia/obstetrícia, e no desempenho do atendimento de outras atividades a gente encontra um pouco de dificuldade. [...] Fui devagarinho me aprimorando com os colegas... me sinto ainda angustiado... sempre vou ter que melhorar"(MED -Equipe 5)

Um fator que influencia diretamente nesta situação de insegurança é, sem dúvida, a formação acadêmica tradicional que esses profissionais receberam durante seus cursos de graduação, baseados em modelos flexinerianos e estáticos, com currículo rígido e pouco conectado com as reais necessidades da população (SANTOS; CUTOLO, 2003). A falta de preparo para lidar com a população pode prejudicar as relações que deveriam se estabelecer entre o trabalhador e o usuário, desencadeando o processo de estresse nestes profissionais.

Alguns trabalhadores consideram que se houvesse um preparo anterior e contínuo às atividades, traria menor desgaste e ansiedade, pois saberiam lidar com as situações presentes na relação trabalhador/usuário.

"No começo foi muito estressante, foi muito difícil, porque a população cobrava isso, então eles falavam - Não é isso que a gente quer. Isso aqui não resolve nada!-Se a gente tivesse uma retaguarda melhor no início, teria sido mais fácil. O fato de fazer um curso específico para o Programa de Saúde da Família iria mudar muita coisa" (ENF- Equipe 3).

"A falta de preparo atrapalha na resolução das tarefas, dos problemas...isso torna a tarefa desgastante. Eu acho que deveria ter capacitação seguindo com você...anterior e seguindo... porque as coisas mudam muito, a população muda muito, o desejo deles em relação à gente muda muito..."(ENF -Equipe 1) 
De acordo com Santos e Cutolo (2003), um processo de capacitação contínuo e eficaz das equipes é necessário, de modo a poder atender às necessidades trazidas pelo dinamismo dos problemas, possibilitando um aperfeiçoamento profissional através da educação permanente. Esse mecanismo de atualização é importante para o desenvolvimento da própria concepção da equipe e da vinculação dos profissioais com a população, características que fundamentam todo o trabalho do Programa de Saúde da Família (BRASIL, 1998).

Compreendemos que a Saúde da Família se abre para um trabalho com maior horizontalidade e flexibilidade, permitindo assim maior autonomia e criatividade dos trabalhadores. Porém, observa-se que a instituição não promove apoio adequado aos profissionais para atuarem desta forma, podendo levar ao aparecimento de outro risco psicossocial que é a falta de capacidade de resolução dos problemas que podem levar ao estresse ( EUROPEAN AGENCY, 2000).

Os trabalhadores referem a necessidade de habilidades para enfrentarem as diversas situações presentes no cotidiano das famílias, além de uma retaguarda para a resolução dos problemas, e assim o trabalho fica menos desgastante.

"[...] A gente foi entrando nas famílias e a gente foi vendo os problemas das famílias e que a gente não tinha como resolver. Difícil é você não levar isso, porque eu chego numa família e a família está com um problema social, e eu não consigo resolver...eu ainda não aprendi a separar os problemas daqui..."(ACS- Equipe 3).

"O que eu considero desgastante.. quando a gente vê um problema numa família, que por exemplo precisa passar por um médico...e aí a gente não consegue marcar, não consegue agendar nada... e aí a gente fica né, assim frustrada..."(ACS-Equipe 4).

"O que é desgastante é você não conseguir terminar aquilo, você não tem onde encaminhar o paciente, você não tem o que fazer, você começa uma coisa e não tem como... a gente não tem uma assistente social no bairro. O PSF tem que dar conta de tudo. E eu acho duro sabe.. porque a gente não consegue dar conta de tudo... a gente não dá conta de quase nada."(ENF- Equipe 4)

O desgaste expresso nas falas desses trabalhadores é um dos sintomas físicos relacionados ao processo de estresse. Ele é uma das características da síndrome da fadiga, pois segundo França e Rodrigues (1999), a fadiga pode ser definida como um desgaste de energia física ou mental, que pode ser recuperada através do repouso, alimentação ou orientação clínica específica. A fadiga poderá 
ter repercussões sobre vários sistemas do organismo, provocando múltiplas alterações de funções que conduzem a uma diminuição da performance no trabalho em graus variáveis, ao absenteísmo no trabalho e a uma série de distúrbios psicológicos, familiares e sociais.

Dessa forma, os profissionais das equipes de Saúde da Família necessitam de apoio para a resolução dos diversos problemas da população. Este apoio envolve desde o planejamento do trabalho, recursos materiais disponíveis, até uma capacitação contínua e permanente de todos os profissionais envolvidos, para que possam trabalhar com competência e criatividade, promovendo a saúde da população.

Função na instituição: "A gente faz duas coisas, a mesma enfermeira que é do PSF é a enfermeira da unidade" (ENF-Equipe 5).

Recentes teorias afirmam que o conceito de trabalho está atrelado a experiência de convivência sadia, respeito, compromisso e que contribua na qualidade de vida (SILVA, 2000).

Jacques (1996) afirma que os diferentes espaços de trabalhos oferecidos constituem-se em oportunidades diferenciadas para a aquisição de atributos qualificativos da identidade do trabalhador.

À medida que o indivíduo está inserido no contexto organizacional, está sujeito a diferentes variáveis que afetam o seu trabalho.

Para que se atinjam a produtividade e qualidade, é preciso ter indivíduos saudáveis e atributos de qualidade. Em contrapartida, a organização atua algumas vezes, pressionando o indivíduo, levando-o a estados de doenças, de insatisfação e desmotivação (SILVA, 2000).

Estudos enfocam que os estressores organizacionais têm se apoiado nas teorias de papéis (FRANÇA; RODRIGUES, 1999).

Analisando os discursos dos entrevistados, foi extraído como risco psicossocial a sobrecarga de papéis.

Cox et al. (2000) apresentam uma categoria de risco psicossocial a qual definem por "Papel na Organização". 
Papel é toda função acompanhada de um conjunto mais ou menos característico de condutas próprias para uma função, que você desempenha em um momento de sua vida. O tipo de papel que uma pessoa pode desenvolver em face de determinada situação é definido pela combinação de suas características da personalidade e pelas expectativas que o ambiente psicossocial que a circunda tem em relação ao papel que a pessoa deve desempenhar (FRANÇA; RODRIGUES, 1999).

Desempenhar um papel adequado ou coerente com o momento que está sendo vivido não só facilita a interação social como também permite que ela se efetive de maneira adequada. Além disso, quando a pessoa tem claro para si qual é seu papel, isto a ajuda a posicionar-se face às situações, dá-lhe mais confiança e propicia o desenvolvimento de um conceito sobre si mesma mais consistente.

Alguns fatores principais constituem esta categoria de estressores organizacionais. Os mais enfocados são: ambigüidade, incompatibilidade, conflito e sobrecarga de papel (FRANÇA; RODRIGUES, 1999).

Os trabalhadores das Equipes de Saúde da Família de nossa pesquisa expressam situações onde há atribuições envolvendo vários papéis, e para eles o ajuste a todas as funções nem sempre é adequado, tornando-os sobrecarregados. Embora este risco psicossocial tenha sido levantado por todas as categorias profissionais, os enfermeiros foram unânimes em dizer que assumem vários papéis (Quadro 6). Isto ocorre, porque, com a implantação do PSF junto às Unidades Básicas de Saúde já em funcionamento, alguns profissionais que estavam nestas unidades, como é o caso e alguns enfermeiros, agora têm a função de assumir também, as atividades do Programa.

"Se eu saio da Unidade, eu vou ficar preocupada, porque vai ficar descoberta de enfermeira... Se chega uma urgência, você fica com aquilo...então não dá para sair, você tem que falar para o paciente:- se tiver condição de trazer aqui traga, pra gente ver- E tem a parte da gerência também... é uma parte burocrática, que você tem que estar ali em cima, então tudo o que quebra, tudo o que...tudo você tem que dar conta, tudo é você que tem que fazer e pronto" (ENF- Equipe 6).

"Uma coisa que acontece diariamente, você tem que estar ligada com as coisas da Unidade, escala de funcionários... você sabe, você é enfermeira e você sabe...então eu estou numa reunião da nossa equipe e chega um e fala :- Fulana faltou e agora? Como é que fica?- Então eu tenho que sair, resolver assuntos de escala, telefone, laboratório...Enfim, e atrapalha" (ENF- Equipe 5). 
A sobrecarga de papel é observada quando a pessoa possui um número grande de papéis. Não deve ser confundida com sobrecarga de trabalho, embora sua coexistência seja freqüente (FRANÇA; RODRIGUES, 1999).

Quando comparamos a freqüência do risco "sobrecarga de papéis" entre as categorias profissionais, observamos que há uma diferença expressiva quanto à identificação deste como condição de risco no ambiente de trabalho entre os $\mathrm{ACS}_{\mathrm{s}} \mathrm{e}$ os demais membros da equipe. Enquanto este risco aparece em 16\% dos Agentes Comunitários de Saúde, para médicos, enfermeiros e auxiliares de enfermagem está presente nas "falas" de 100\% deles. Esta diferença talvez ocorra pelas características do trabalho desenvolvido pelos ACS, pois sabemos que as suas principais atribuições são realizadas diretamente com a comunidade e fora da unidade; sendo assim, as atividades que devem ser realizadas na unidade, para o atendimento da demanda, ficam para os demais membros da equipe.

Os profissionais, especialmente enfermeiros e médicos, expressam as diversas funções que assumiram na Unidade, sendo uma delas a de gerente.

A gerência das Unidades Básicas de Saúde possui particularidades que a diferenciam de outros setores e estão relacionadas ao seu objeto de trabalho que é a assistência à saúde da população adscrita (PENNA et al., 2004). Nessa assistência o gerente tem a responsabilidade de coordenar as atividades e dos recursos hunanos e materiais para o atendimento. Esta atividade é exercida por profissionais de nível superior, pela complexidade envolvida.

Para o funcionamento adequado das $U_{B S}$, hoje, é necessário ultrapassar os limites internos da unidade e que os gerentes assumam e reconheçam o lugar da comunidade (PENNA et al.,2004). Nesse sentido, é preciso envolvimento e isto significa comprometimento destes trabalhadores, o que implica compromisso revelado na redução de tempo de descanso, nas horas trabalhadas além das formais, nas atividades extras. Mas para esta atuação, estes profissionais devem possuir conhecimentos e habilidades aperfeiçoados de planejamento e controle de atividades organizacionais, para que a instituição atinja seus objetivos (JUNQUEIRA, 1990).

Assumir várias funções pode levar a uma sobrecarga de papéis e ela produz sintomas de estresse psicológico e físico como: tensão, insatisfação com o trabalho, redução da auto-estima, percepção de ameaça, ansiedade, aumento dos níveis de colesterol e do tônus cardíaco. 
Os entrevistados expressam dificuldades para assumirem vários papéis.

“...A gente tem que fazer pela UBS e pelo PSF. O que seria oito horas só para o PSF está dividido...metade para a UBS e metade para o PSF então é muito estressante, você quer fazer, vê que tem necessidade de fazer alguma coisa, mas você fica preso com a falta de tempo" (AUX- Equipe-5)

“...A gente faz duas coisas, É uma unidade mista, então a mesma enfermeira que é do PSF é a enfermeira da Unidade. Você fica o tempo todo ligada em tudo...tanto na questão da Unidade quanto do PSF, então você tem que se desdobrar pra dar conta das duas coisas... eu acho que o estresse mesmo é de um monte de coisa junto..." (ENF- Equipe 5)

“...Como eu posso sair da Unidade para fazer qualquer coisa lá fora se eu tenho uma unidade na minha mão? De manhã a Unidade é minha, a tarde eu faço PSF... então sabe...começou errado..."(ENF -Equipe 2)

Nessas situações, o trabalhador escolherá o papel que terá prioridade, mas aceitando o fato de que estará dando menor atenção a outro.

Evidentemente, esse fato é gerador de estresse, à medida que a pessoa terá dificuldades de se situar nas tarefas que lhe cabem, e seu desempenho pode vir a ser prejudicado, como foi observado nos relatos dos trabalhadores entrevistados que consideraram esta situação estressante.

Notamos que há um esforço dos trabalhadores para cumprir suas tarefas, mas a falta de tempo e a sobrecarga de papéis prejudicam a assistência prestada às famílias deixando-os, muitas vezes, frustrados.

A sensação de desgaste e tensão é expressa pelos trabalhadores, quando a população não reconhece os esforços realizados para o cumprimento das tarefas deste novo modelo de assistência.

[...] Perdem receita, não fazem o tratamento corretamente, chegam cobrando da gente obrigações nossas, mas as deles não... Eles são muito descompromissados... às vezes eu saio daqui frustrada, frustrada, frustrada..." ( ENF- Equipe 2).

"Eu fico muito triste quando a gente vai assim com muito carinho, para entrar na vida daquela família, na área da saúde, e a gente vê o descaso e a má vontade" (ACS- Equipe 5). 
Através destas falas, observamos que os profissionais se sentem frustrados pela pouca participação do usuário. Isto reflete dois aspectos: que a implantação do PSF ocorreu sem a prestação de informações adequadas e suficientes à população, sobre este novo modelo, e a permanência do profissional no modelo anterior, onde considera primordial que as prescrições médicas e de enfermagem sejam cumpridas.

O acesso da população a serviços de qualidade através de políticas públicas saudáveis não é suficiente. Faz-se necessária a mobilização da população (BUSS, 2000). É importante ressaltar a definição da Carta de Otawa que refere a promoção de saúde como "um processo de capacitação da comunidade para atuar na melhoria de sua qualidade de vida e saúde, incluindo uma maior participação no controle deste processo" (BUSS, 1990, p.170).

Observa-se em nossa pesquisa que a clientela não compreende o papel exercido pelos profissionais, requerendo, algumas vezes, serviços que não são oferecidos por este Programa.

Os trabalhadores se confrontam com a descrença dos usuários em relação ao atendimento, devido à imagem negativa que já possuem do serviço, e muitas vezes, pela falta de informações e respaldo para as soluções dos problemas a nível central. Este fato pode gerar insegurança nos trabalhadores levando à insatisfação no trabalho.

A satisfação no trabalho pode exercer influência sobre o estado emocional do indivíduo, manifestando-se na forma de alegria decorrente da satisfação, ou na forma de sofrimento decorrente da insatisfação (LOCKE, 1976).

Segundo Codo, Sampaio e Hitomi (1995), do choque entre um indivíduo, dotado de uma história personalizada e a organização do trabalho, portadora de uma injunção despersonalizante, emergem uma vivência e um sofrimento que determinarão a saúde na organização e seu funcionamento.

E o sofrimento do indivíduo traz conseqüências sobre o seu estado de saúde e igualmente sobre o seu desempenho, pois existem alterações e/ou disfunções pessoais e organizacionais. Esse sofrimento advém de sentimentos gerados por diversos aspectos e que atingem a organização em todo o seu contexto (SILVA, 2000). 
A vivência depressiva condensa de alguma maneira os sentimentos de indignidade, de inutilidade e desqualificação, ampliando-os. Esta depressão é dominada pelo cansaço. Cansaço que se origina não só dos esforços musculares, mas também dos psicossensoriais. Associados ao cansaço por serem também importantes estão: a fadiga, insatisfação, frustração, angústia, ansiedade, agressividade, hostilidade e outros.

Fica clara a importância do bem-estar e a saúde do indivíduo no trabalho, pois é, no trabalho que se passa a maior parte do tempo. A qualidade de vida está diretamente relacionada com as necessidades e expectativas humanas e com a respectiva satisfação desta. O bem-estar do indivíduo, no ambiente de trabalho, é expresso através de relações saudáveis e harmônicas (KANAANE, 1994).

É possível pensar que existe Qualidade de Vida no Trabalho quando os membros de uma organização são capazes de satisfazer necessidades pessoais importantes através de sua vivência na mesma, o que engloba, portanto, a preocupação com o efeito do trabalho nas pessoas, com a eficácia da organização e com a idéia da participação dos trabalhadores na solução de problemas e tomada de decisões (SILVA, 2000).

A qualidade de vida no trabalho inclui aspectos de bem-estar, garantia da saúde e segurança física, mental e social, capacitação para realizar tarefas com segurança e bom uso de energia pessoal. Ela depende simultaneamente do indivíduo e da organização ( SILVA, 2000).

Carga e esquema de trabalho: "Você acaba fazendo uma jornada maior do que oito horas" (ENF- Equipe 4).

Além da sobrecarga de papéis, o acúmulo de tarefas associado ao ritmo de trabalho implantado nas unidades de Saúde da Família podem gerar sobrecarga de trabalho que é um risco psicossocial descrito por Cox et al., (2000). Em relação a este risco, os autores descrevem condições do ambiente de trabalho, como o seu esquema, gerando sobrecarga no trabalhador. São relacionadas ainda condições como o turno de trabalho e falta de flexibilidade, além de longas horas de trabalho. 
Através da análise das falas, foi observada a presença de longas horas de trabalho. É importante ressaltar que a carga horária foi levantada por todos os profissionais entrevistados (Quadro 6).

Segundo Brito (1991), as cargas de trabalho podem ser definidas como multidimensionais e exprimem fatos em interação a serem integralmente avaliados através da análise do processo de trabalho. Esta carga em si não deve ter a conotação necessariamente de peso e dificuldade, mas como demandas do processo de trabalho. Dessa forma, podemos considerar que a carga de trabalho resulta de uma série de variáveis que dependem de cada indivíduo e das condições em que é realizada a tarefa.

O trabalho das equipes de Saúde da Família apresenta um componente cognitivo intenso e complexo, envolvendo inúmeras variáveis, entre elas: a complexidade crescente dos problemas da realidade sanitária, confronto com o sofrimento, falta de comunicação na equipe, enfim, condições que nem sempre podemos prever antecipadamente, causando sofrimento durante o trabalho.

Embora a carga horária de trabalho no Programa de Saúde da Família seja de 40 horas semanais, o número intenso de atividades previstas para os profissionais, como já citadas anteriormente, faz com que muitas vezes, estes trabalhadores não cumpram suas funções durante o período de trabalho, realizando hora extra para conseguir concluir as atividades. Isto pode gerar um elevado nível de ansiedade no trabalhador.

"[...] Você acaba fazendo uma jornada maior do que oito horas, ainda mais que eu levo coisas para casa , né... Ontem eu levei várias coisas para conferir, essas coisas, né..."(ENF-Equipe 4).

"É desgastante... chega no final do dia... não ter conseguido fazer tudo o que eu queria ter feito no dia, não ter conseguido concluir" (AUX-Equipe 6).

"É complicado porque o fato da gente trabalhar oito horas... eu trabalhava num posto normal que era quatro horas, então era bem mais fácil. Então eu tive que me readaptar assim no meu dia-a-dia. Eu tive que me reorganizar para trabalhar oito horas, porque é puxado, não sobra muito tempo" (ENF- Equipe 3).

Os discursos revelam que os trabalhadores não conseguem realizar todas as etapas das atividades durante o período do trabalho, necessitando utilizar horas 
de dedicação no lar para cumprir as exigências das tarefas. Isto pode ser motivo de sofrimento para o trabalhador, pois outras áreas de sua vida estão sendo prejudicadas.

A sobrecarga de trabalho, tanto em termos quantitativos como qualitativos, é fonte freqüentemente associada ao estresse (FORNÉS, 1994). O excesso de horas trabalhadas reduz a oportunidade de apoio social ao indivíduo, causando insatisfação, tensão e outros problemas de saúde.

Conforme já descrito anteriormente, há um número insuficiente de trabalhadores nas Equipes para realizarem todas as tarefas preconizadas pelo Ministério da Saúde, sobrecarregando alguns trabalhadores e prejudicando o atendimento nas unidades.

"Tem dia que é tudo maravilhoso, mas não é todo o dia que tudo corre perfeitamente bem, então eu acho muito cansativo. $E$ o fato de você ficar..., o profissional do Programa de Saúde da Família ter que ficar oito horas, ele obrigatoriamente tem que ter carga dobrada. Se estiver tudo bem com todo mundo, é uma coisa, mas se alguém da equipe tem algum problema de saúde, então sobra muito serviço para os demais membros"( MED- Equipe 2).

"[...] Pela manhã eu ajudo a cobrir em todo o lugar. A gente está com um déficit de funcionário...funcionário de férias, funcionário de licença-gestante e tem funcionário de licença-saúde. Então a gente fica sobrecarregada mesmo na questão do serviço que a gente quer fazer, porque tem uma linha de trabalho que a gente está desenvolvendo, então a gente se sente frustrada por não conseguir realizar aquilo que a gente gostaria de estar fazendo no mesmo ritmo...então dá uma certa frustração" (AUX- Equipe 2).

O número de atividades preconizadas pelo $\mathrm{MS}$, os recursos insuficientes e o volume de atendimento geram um ritmo intenso de trabalho sendo considerado, algumas vezes, desgastante.

"O que é desgastante após uma jornada de trabalho é o volume de atendimento... 0 que mais me estressa é o volume de atendimento. A minha intenção como médico do PSF não é fazer PA, o pronto-atendimento, aquela coisa rápida, mas um atendimento de qualidade, o que demanda tempo de consulta, e com isso entope de paciente e a gente acaba ficando sobrecarregado" (MED- Equipe 6)

A elevada demanda do serviço favorece um atendimento com pouca qualidade e o profissional que atua no modelo de assistência de Saúde da Família, 
conhecendo as necessidades da realidade sanitária, sente-se insatisfeito com a assistência prestada.

Além da grande demanda interna, a sobrecarga de trabalho pode se agravar, de acordo com a equipe, em decorrência de reqüentes solicitações da coordenação municipal (SILVA;TRAD, 2005).

O número insuficiente de trabalhadores e as exigências das tarefas são expressos nas falas dos profissionais como fator gerador de insatisfação no trabalho, cansaço e pouco desempenho para a realização das atividades do Programa.

As longas horas de trabalho despendidas pelos profissionais e o número elevado de atividades, além de sobrecarregá-los física e mentalmente, dificultam o seu aprimoramento técnico-científico.

Este fato é reportado pelos entrevistados:

"[...]Eu tenho especialidade médica, eu fiz pneumologia e eu gosto muito, quero me dedicar! Então eu gostaria de ficar meio período no Programa de Saúde da Família e as tardes no meu consultório, mas como não é possível, então eu vou ter que sair do Programa de Saúde da Família, porque realmente não dá para ficar 9 horas num lugar e depois ainda fazer consultório, assim fisicamente e mentalmente é muito cansativo"( MÉD- Equipe 2).

"A instituição está sempre promovendo cursos. Nem sempre a gente tem disponibilidade por causa da demanda do serviço. Falta disponibilidade para ir às palestras" (AUX- Equipe 2).

Os trabalhadores relatam a necessidade de se aprimorarem para a assistência à população, mas a sobrecarga de atividades é um dos fatores que dificultam este processo.

O profissional da Equipe de Saúde da Família, segundo normas do MS, precisa ser capaz de atuar com criatividade e senso crítico, mediante uma prática humanizada e competente que envolva ações de promoção, prevenção, recuperação e reabilitação (BRASIL, 1998). Nessa perspectiva é necessário o redirecionamento do processo de trabalho devido às novas competências exigidas do trabalhador da saúde. Estes profissionais devem constantemente se aprimorar frente às práticas de saúde contemporâneas. Esta realidade vem reafirmar a necessidade de educação continuada e permanente para estes trabalhadores. 
Além do prejuízo no aprimoramento destes profissionais, outras áreas de sua vida podem estar sendo prejudicadas, pelo volume de atendimento e sobrecarga de trabalho como é o caso da alimentação. A distância do local de trabalho, faz com que os trabalhadores diminuam o tempo de descanso, por exemplo, o horário de almoço, para conseguir realizar todas as suas tarefas:

"[...]É muito cansativo no Programa de Saúde da Família as nove horas de jornada de trabalho. Eu entro às 8 e saio às 5, eu tenho que cumprir uma hora de almoço, pelo fato do posto ser muito longe, muitas vezes, eu nem vou almoçar em casa. Porque com esse horário de almoço, eu almoço aqui e fico por aqui mesmo, eu acho muito cansativo. Na minha opinião o Programa de Saúde da Família deveria ser feito só por profissionais que pudessem trabalhar quatro horas só, é muito mais tranqüilo. Porque aí você recarrega as energias para no outro dia estar disposto, porque olha o dia todo..."( MED-Equipe 2).

O trabalhador reconhece como intenso o seu ritmo de trabalho e a necessidade de utilização de alguns meios para torná-lo mais ameno, ou seja, menos cansativo, a fim de evitar o desgaste emocional e conseqüentemente 0 estresse profissional.

Se os ritmos de trabalho são mantidos no nível máximo de tolerância, seus efeitos se farão sentir não somente à distância, mas na mesma semana, entre o começo e o fim dela, e até mesmo entre o começo e o fim do dia (DEJOURS, 1992).

"O que acho mais desgastante, é ficar aqui dentro na hora do almoço. Porque normalmente nós almoçamos aqui, uma hora de almoço. Normalmente eu não faço hora de almoço, eu faço em meia hora, quarenta minutos e já começo a trabalhar. Então isso é desgastante, sabe..."(ENF-Equipe 2).

“Eu acho que a pior área para mim hoje é em relação à alimentação, que é a área que eu acho que eu tenho mais dificuldade de me cuidar. Porque aqui no posto nós temos um local para a refeição, que é a área de serviço.. São os minutinhos que eu saio do posto e fico longe dessa situação para tentar melhorar isso, mas é a área na minha vida que eu não consegui resolver melhor" (MED-Equipe 4). 
Os trabalhadores expressam a necessidade de diminuir as horas de trabalho em função de sua vida pessoal e pelo desgaste das inúmeras responsabilidades deste modelo de assistência.

"Se fosse menos horas muito melhor, porque a gente também tem uma vida lá em casa, né, logicamente que seria muito melhor... Se tivesse uma horinha a mais para resolver as coisa de casa...então se fosse uma hora a menos, a gente renderia muito mais" (AUX-Equipe 3).

O trabalho absorve quase todo o tempo e o trabalhador se sente frustrado e insatisfeito com o tempo que sobra.

"[...] é.. o trabalho acaba absorvendo a maior parte do tempo e aí o que sobra é assim...é um período que eu estou exausta... Mesmo que eu tenha um tempo, só tenho a noite, e é difícil fazer tudo que eu gostaria de fazer, tudo que eu gostaria de estar fazendo porque eu já estou muito cansada....oito horas para desenvolver as atividades do PSF eu acho adequado que o profissional fique os dois períodos e tal. Mas pensando assim no lado profissional, eu acho que o ideal seriam seis horas, ou mesmo as oito sem precisar fazer outro turno no consultório, e conseguisse se manter financeiramente e não é o que acontece hoje em dia" (MED- Equipe 1).

"Eu não estou satisfeita...se a gente tivesse 6 horas seria melhor"(ACS-Equipe 1).

"É difícil...você acaba fazendo uma jornada maior que as oito horas, ainda mais que eu levo coisas para fazer em casa"( ENF- Equipe 3).

Cary Cooper (1992 apud WARREN; TOLL, 1998) ${ }^{2}$ considera um dano potencial causado à família e ao desempenho em virtude de longas horas de trabalho.

Controlando as horas de trabalho, poderíamos não apenas reduzir o conflito em casa/no trabalho e os perigos do estresse excessivo, mas também liberar tempo que poderia ser utilizado para gerenciar o estresse.

Precisamos avaliar nosso desempenho de acordo com o trabalho, não com as horas de trabalho (WARREN;TOLL, 1998). O fato de um indivíduo ser

\footnotetext{
${ }^{2}$ WARREN, E; TOLL,C. Como dominar seu stress: como indivíduos equipes e organizações podem equilibrar pressão e performance. Tradução: Tereza Queiroz. Rio de Janeiro: Infobook; 1998.235p.
} 
geralmente capaz de lidar com uma determinada carga de trabalho, em particular, não significa que possa sempre caminhar naquele ritmo sem períodos de restabelecimento.

Relacionamento interpessoal no trabalho: "O relacionamento com os colegas é sempre desgastante, trabalhar em equipe não é fácil"(AUX- Equipe 5)

Ao analisar as entrevistas, observamos que todas as categorias profissionais relataram o conflito no trabalho em equipe como uma das dificuldades encontradas no cotidiano de seu trabalho. Estas situações ou riscos foram incluídos nesta unidade temática e representam aspectos de relacionamento no trabalho. Para Cox et al. (2000), a este tema incluem-se riscos psicossociais como: isolamento físico e social, relacionamento precário com superiores, conflito interpessoal e falta de suporte social.

A reestruturação do modelo de atenção à saúde modifica os objetivos e os focos das ações, transformando atitudes, posturas e comportamentos, e a partir desta modificação, surgem dificuldades técnico/administrativas bem como emocionais.

A forma como foi implantado o PSF na maioria dos municípios brasileiros, em especial em nossa unidade de campo, pode gerar conflitos nas relações que deveriam se estabelecer entre os próprios profissionais e entre eles e a comunidade assistida.

As unidades de Saúde da Família são mistas, isto é, funcionam conjuntamente nas Unidades Básicas de Saúde tradicionais. Alguns profissionais das Equipes de Saúde da Família realizam concomitantemente atividades no modelo tradicional e no novo modelo de assistência. Existem trabalhadores que foram selecionados para trabalhar exclusivamente para o PSF, mas há aqueles que trabalham na unidade e não fazem parte da equipe de saúde da família.

Os entrevistados consideram, como um dos entraves para a organização do processo de trabalho, a falta de compreensão de alguns colegas que trabalham nas Unidades. 
"[...] Os colegas da Unidade não aceitam o PSF, não sei se por ciúmes... enfim nem os auxiliares de enfermagem... não vou falar da enfermeirra porque as duas enfermeiras fazem parte do PSF e da unidade, mas os auxiliares de enfermagem, os funcionários em geral, e alguns colegas médicos, eu acho que não aceitam ainda" (MÉD- Equipe 5).

"[...] Existem muitos comentários:- Ah o pessoal do PSF só faz reunião! Só reúnem, não fazem nada! O que é o PSF?- então assim, isso me incomoda muito.. às vezes sabe gera um fuxico" (ENF- Equipe 5)

Como podemos verificar nas falas, algumas atividades desenvolvidas pelas ESF não são compreendidas pelos demais trabalhadores das unidades.

O PSF tem como pressuposto básico o trabalho em equipe, composto de vários profissionais de nível superior e médio, com o objetivo de realizar uma intervenção de caráter primordialmente preventivo e de promoção à saúde, em uma população territorialmente adscrita, visando especialmente à educação de grupos de risco, com maior propensão a adoecer ou a complicar, em função de patologias preexistente e/ou falta de informação (SANTOS; CUTOLO, 2003).

Dessa forma configura-se uma nova concepção de trabalho, uma nova forma de vínculo entre os membros de uma equipe, diferentemente do modelo biomédico tradicional, permitindo maior diversidade das ações e busca permanente do consenso. Tal relação, baseada na interdisciplinaridade e não mais na multidisciplinaridade, requer uma abordagem que questione as certezas profissionais e estimule a permanente comunicação horizontal entre os componentes de uma equipe (SANTOS; CUTOLO, 2003).

Para que isto ocorra, faz-se necessário que os profissionais compreendam a importância do trabalho em equipe. Cada profissional pode ter uma visão de um determinado fato e todas as ações a serem desenvolvidas devem ser discutidas no grupo, para a promoção da saúde da população.

"[...] A gente sente um pouco de dificuldade de trabalhar em grupos. Eu sei que não são fatores que influenciam no bom andamento de um grupo, qualquer que seja ele, mas eu acho que talvez, se fôssemos melhor preparados para trabalhar em equipe, talvez isso poderia... Não sei também... De repente também não, porque cada grupo é um grupo, é tão diferente.. (ENF-Equipe 5). 
"[...] Tem coisa que não bate muito a idéia , igual, vamos supor, eu chego aqui, e vamos supor, você é alguém do meu grupo e eu chego e venho trazer o problema para você, pra você me ajudar, aí de repente pra mim é um problema, e eu sei que é um problema para aquela pessoa, e pra você, você vê com outros olhos, aí fica difícil...Geralmente, onde é um grupo, geralmente sempre tem um que tem uma idéia e tem outro que tem outra, mas aí tem que discutir..."(ACS- Equipe 2).

Como podemos verificar nos relatos anteriores, existem deficiências relacionadas ao preparo dos profissionais para trabalharem em equipe e estas são apontadas como um fator que repercute no trabalho. Destacou-se aqui o fato de que a temática do trabalho em equipe, que envolve dimensões administrativas, psicológicas etc., é pouco discutida, interferindo no processo de trabalho.

A ampliação do objeto de intervenção para além do âmbito individual e clínico, demanda mudanças na forma de atuação e na organização do trabalho. Cada profissional desempenha sua profissão em um processo de trabalho coletivo, cujo produto deve ser fruto de um trabalho que surge da contribuição específica das diversas áreas profissionais ou de conhecimento. Espera-se que os integrantes das equipes sejam capazes de "conhecer e analisar o trabalho, verificando as atribuições específicas e do grupo, na unidade, no domicílio e na comunidade, como também compartilhar conhecimentos e informações" (BRASIL, 2001).

Estudos sobre o trabalho em equipe no PSF revelaram ausência de responsabilidades coletivas do trabalho e baixo grau de interação entre as categorias profissionais (PEDROSA; TELES, 2001).

Esta situação se reitera nas falas dos trabalhadores entrevistados:

"[...] O relacionamento é complicado, tem dia que você está de mau humor da parte da médica, tem dia que você tem mau humor da própria colega... se bem que aqui os funcionários, mais ou menos já se conhecem e quando um está arretado, ele também já fica na sua. Mas de uma maneira geral o problema são os profissionais de nível universitário... Tem semana que você é questionado sobre o paciente que você agendou:- Por que você colocou este paciente? Isso aí é porcaria não precisava ter entrado! É difícil, então às vezes eu saio e deixo falando" (ENF-Equipe2).

"[...] Alguns colegas não têm muito interesse. Eles ficam te pressionando para você não apresentar uma determinada quantidade de visitas. Se eu faço 100, eles querem que...aqueles que não gostam de trabalhar, que que você apresente 40, 60, né. ...porque daí o chefe vai pegar no pé deles..(ACS-Equipe 5). 
A multiprofissionalidade por si só não é condição suficiente para garantir a recomposição dos trabalhos parcelares na direção de uma atenção integral. Como salienta Schraiber et al. (1999), a eficiência e a eficácia dos serviços requerem uma modalidade de trabalho em equipe que traduza uma forma de conectar as diferentes ações e os distintos profissionais.

Ao estudar o trabalho em equipe, é importante conhecer como cada profissional conjuga seu trabalho no âmbito individual e coletivo e identificar evidências de articulação das ações desenvolvidas pelos diferentes profissionais (SILVA; TRAD, 2005). Em uma equipe multiprofissional, a articulação refere-se à recomposição de processos de trabalhos distintos e, portanto, à consideração de conexões e interfaces existentes entre as intervenções técnicas peculiares de cada área profissional (CIAMPON; PEDUZZI, 2000).

De todo o modo, com base em Peduzzi (2001), é possível afirmar a existência de articulação entre as ações executadas pela maioria dos profissionais, porque eles devem buscar conhecer o trabalho do outro e incorporá-lo na execução do seu próprio trabalho.

Vale a pena lembrar que os profissionais que compõem as Equipes de Saúde da Família ocupam uma posição diferenciada no âmbito da hierarquia profissional e socioeconômica. Isto pode prejudicar a interação entre eles, como observado a seguir.

"[...] Tem aquela coisa assim, de quem manda, quem não manda... Quem que coordena...então fica uma coisa assim..não está certinho como se fosse uma equipe, cada um com a sua função, sabendo direitinho...apesar de já estarmos trabalhando em equipe há três anos, eu sinto que a gente não chegou no ponto ainda, nós não nos afinamos ainda não ..." (MED- Equipe 1).

Peduzzi e Palma (1996) destacam a supervisão como meio de auxiliar a interação entre os profissionais de saúde no trabalho em equipe, seja pelo seu caráter gerencial, educativo ou de articulação política.

Este fato é comprovado nas entrevistas quando um trabalhador se refere à gerência como uma peça relevante no relacionamento da equipe. 
"[...] Um trabalho tem sido feito desde o início com a gerência... Ela tem sido assim uma peça fundamental durante esses anos todos, no relacionamento, quando ela percebe que a coisa não está indo conforme a gente tinha planejado, ela reúne o grupo de novo, é... e torna a explicar qual o objetivo, e assim, é um trabalho diferente..."( $A \cup X-$ Equipe 1).

Concordamos com Paim (1993) que, embora os treinamentos e as capacitações possam contribuir para uma progressiva politização e socialização do saber, eles podem repercutir sobre as relações de poder no contexto do trabalho.

Quando os profissionais não estão preparados para o trabalho em equipe, ou quando não existem treinamentos e/ou orientações adequadas por parte de supervisores para o trabalho, qualquer situação pode ser desgastante nas relações que se estabelecem entre eles.

"[...] O relacionamento com os colegas é sempre desgastante, trabalhar em equipe não é fácil, não é fácil não, às vezes a gente desgasta um pouco sim. Tentando fazer alguma coisa em pouco tempo, e aquele que tem o tempo todo poderia ajudar mais... (AUX-Equipe 5).

"[...] Às vezes surge um desentendimento né, nem sempre é cem por cento uma maravilha, porque acho que em um grupo é, muitas vezes a gente... Cada um tem a sua opinião, né... então às vezes acaba sendo desgastante" (ACS-Equipe 1).

Os relatos anteriores demonstram que a falta de interação entre os membros das equipes pode trazer conseqüências na organização do trabalho, bem como na assistência à comunidade, gerando, muitas vezes, situações desgastantes na relação com a comunidade.

As Equipes de Saúde da Família devem se responsabilizar por um conjunto de problemas muito bem delimitados e pelo planejamento e execução de ações capazes de resolvê-los, o que ocorreria por meio de "vinculação de cada equipe a um certo número de usuários previamente inscritos" (CAMPOS, 1992). Portanto, este novo modelo de assistência supõe que deva haver envolvimento dos trabalhadores das equipes com a população de seu território de abrangência, para o diagnóstico e intervenção na realidade sanitária. Mas para que isto ocorra, também é preciso que a população repense o seu estilo de vida e se sinta co-responsável pela busca ativa da solução para os seus problemas. 
A incompreensão e a falta de respeito podem prejudicar as relações entre o trabalhador e a comunidade, desencadeando sentimentos que podem levar ao estresse profissional.

A população não compreende qual o papel do profissional da Equipe de Saúde da Família, reagindo, muitas vezes, com desrespeito.

"É desgastante... A incompreensão, a falta de respeito da população. Sabe você faz, faz, faz como profissional, e eles não fazem a parte deles"(ENF- Equipe 2).

[...] Eles ficam com bronca da unidade de saúde e então eles tentam descarregar em cima da gente, e nessa hora eu fico muito frustrada e triste" (ACS- Equipe 5).

Segundo os entrevistados, o relacionamento interpessoal, seja ele com a comunidade ou com os próprios colegas, é um fator desgastante no contexto do seu trabalho, o que significa que o trabalho do PSF necessita de novas relações entre os membros da equipe e com a comunidade assistida, somada a responsabilidade de ambas as partes.

Dessa forma, considerando que um dos pressupostos básicos da estratégia de saúde da família é o trabalho em equipe, devemos refletir sobre a necessidade do preparo dos profissionais para este tipo de trabalho e para as responsabilidades que dele emanam.

Relação Trabalho/Família: "Você chega em casa bem cansada... é bem difícil!" (ACS- Equipe 1).

As exigências do trabalho e do lar foram identificadas como um risco psicossocial presente no cotidiano dos sujeitos de nossa pesquisa.

Existem indícios de que as pessoas estão começando a pensar seriamente em melhorar a forma como o trabalho é organizado para tornar a vida menos estressante, tanto para o homem quanto para a mulher. Também existem evidências de que algumas suposições feitas no passado com respeito ao relacionamento entre nossas vidas profissionais e nossas vidas em casa estão sendo desafiadas (WARREN; TOLL, 1998). 
Conciliar a atividade profissional com o cotidiano familiar nem sempre é tarefa fácil, todavia, os trabalhadores, cada um com a sua história de vida, têm buscado o alcance da realização profissional.

O trabalho remunerado quase sempre parece exigir atenção e comprometimentos totais, o que pode fazer com que negligenciemos outros aspectos de nossas vidas, como a família, saúde e amigos (WARREN;TOLL, 1998).

Os profissionais de nosso estudo desenvolvem inúmeras atividades na Unidade, bem como, na comunidade e, por isso, estão suscetíveis ao conflito entre as necessidades do trabalho e da família. É possível observar que um dos fatores que interfere na relação trabalho/família são as longas horas de permanência no trabalho, as quais impedem o trabalhador de dispensar um maior tempo de dedicação à família.

A relação do trabalho com a vida familiar está presente nas falas dos entrevistados, revelando como interfere no seu cotidiano.

"[...] Ah! É difícil...é difícil, porque eu moro só eu e minha mãe. Então assim...eu procuro dar o máximo de tempo para minha mãe...porque é difícil conciliar...eu tenho que levar minha mãe no médico..quando tem reunião, grupos, eu sempre ultrapasso o meu horário...é difícil" (ENF- Equipe 4.)

"[...] Você chega em casa bem cansada, você tem que, assim ter o trabalho psicológico muito bom pra você não misturar, né? pra você não passar esse cansaço para os seus filhos, né, porque eles querem a sua atenção, né... é bem difícil..é bem difícil..." (ACS-Equipe 1).

É possível perceber que os trabalhadores consideram importante conseguir tempo para conciliar o trabalho e a família.

Com relação aos efeitos do trabalho sobre a vida familiar, Seligman-Silva (1990) destaca a complexidade dessa interação expressando que as vivências irão ecoar no ambiente laboral, da mesma forma que os fenômenos que o trabalho imprime no conjunto psicofísico do trabalhador irão se fazer sentir, na qualidade de seu convívio nas horas em que permanece em casa.

Os profissionais das equipes de Saúde da Família, desenvolvendo atividades voltadas para a manutenção/preservação da saúde da população em geral, podem não dispor de mecanismos que garantam a administração de sua vida 
pública e privada com a tranquilidade necessária à manutenção de seu equilíbrio mental.

"No começo do meu serviço... era difícil porque eu levava tudo para casa...os problemas das famílias de fora...hoje não, hoje eu largo...nem misturo uma coisa com a outra, não misturo nem o trabalho com a família e nem os problemas pessoais das pessoas..."(ACS- Equipe 1)

Como verificamos, esquecer tudo o que acontece no lar não é tarefa fácil, mas a experiência profissional e o aprendizado podem atuar positivamente neste processo, possibilitando ao trabalhador separar as necessidades familiares e do trabalho, como podemos verificar a seguir.

A inserção feminina no mercado de trabalho provocou alterações significativas em seu cotidiano. Como vimos, $87,5 \%$ dos profissionais entrevistados são mulheres e $60 \%$, casadas. A relação do trabalho com a vida familiar está presente nas falas das mulheres revelando como interfere no seu cotidiano como mulher, mãe e esposa.

"[...] Olha é difícil porque eu trabalho e estudo. É muito difícil, mas na minha casa, eu já..assim...a minha família desde quando meus filhos eram pequenos a gente sempre falou uma coisa :- aqui além de uma família, a gente é uma sociedade, e como são sócios todos têm que participar, todos têm que dividir, do mesmo jeito que você divide o lucro, você divide os prejuízos e o trabalho..."(AUX-Equipe 5).

No relato anterior, podemos perceber a relação da entrevistada com o seu trabalho e a importância da participação do marido e filhos na rotina doméstica. Esse aspecto é reforçado por Sarti (1997) ao afirmar que, com a inserção feminina no mercado de trabalho, a configuração familiar sofreu modificações na sua organização, divisão das tarefas domésticas e educação dos filhos. Assim sendo, além da participação masculina (quando existe), a mulher lançou mão de aparatos sociais, como creches e equipamentos para auxiliar na rotina doméstica (máquinas de lavar roupa e louças, alimentos congelados, freezer e outros), o que alterou o modelo familiar tradicional ( SPINDOLA; SANTOS, 2003). 
“[...] Eu acho que eu deixo a desejar lá em casa. Eu já chego em casa cansada... eu já estou tão cheia de tudo, que às vezes eu quero chegar em casa, tomar banho e me deitar, sabe, esquecer que existe gente para conversar, porque eu já conversei tanto o dia inteiro que eu não quero conversar" (ENF-Equipe 2).

Os trabalhadores sentem-se culpados por não dar a devida atenção (ou que julga-se a mais adequada) à sua casa e aos seus filhos, como também não conseguem dedicar maior parcela de tempo para o desenvolvimento profissional.

Assim, a vida familiar pode ser afetada positiva ou negativamente pelo trabalho dos cônjuges. Quando há mudança para uma rotina em que as oportunidades de estar juntos são trocadas por um ritmo alucinante em que não é mais possível fazer as refeições com os filhos, brincar com as crianças após o jantar, o estresse se reflete na família causando desgaste físico e emocional, gerando doenças e irritação.

Os relatos que se seguem esclarecem esse pensar:

"[...] Difícil... muito difícil..é... o trabalho acaba absorvendo a maior parte do dia, aí o que sobra é assim...é um período que eu estou exausta...exausta. Mesmo que eu tenha um tempo, só tenho à noite e é difícil fazer tudo o que eu gostaria de estar fazendo porque eu já estou muito cansada" (MED- Equipe 1).

"[...] Ai meu Deus! tem dia que fica muito difícil! Ainda bem que eu não tenho muitos porque é ruim quem tem muito, eu tenho um só, e meu filho já é maior, tem dezoito anos, ele já foi se adaptando a me ajudar, então a ser responsável, assim...Porque o dia-a-dia é muito difícil, a gente fica estressado" (AUX-Equipe 3).

"[...] Eu tento esquecer tudo o que acontece lá na minha família. É claro que você fica ligada mesmo dormindo...a gente chega em casa muito cansada, muito estressada. Então eu acho que acaba assim, o que você poderia fazer mais pelo seu filho, que nem no meu caso, o meu menino tem 10 anos, ficar mais próximo e tal... a gente está cansada, tão desgastada, que você faz, mas percebe que deixa a desejar" (AUX-Equipe 5).

[...] O horário, você fica o dia inteirinho aqui, e eu tenho filhas pequenas, então até você se adaptar, fazer as crianças entrar no ritmo da casa no dia, todo dia você tem que fazer a mesma coisa... a sua cabeça fica girando. Está difícil" (ACS- Equipe 3).

Os relatos anteriores deixam transparecer que as entrevistadas sentemse divididas em seu dia-a-dia como trabalhadoras e mães, as atividades do Programa de Saúde da Família comprometem a vida familiar e são revestidas de cansaço e estresse. 
O dia-a-dia com a família, as atividades profissionais, seus interesses pessoais, enfim, um somatório de atribuições realizadas, na maioria das situações de maneira isolada, sem compartilhar, contribuindo, muitas vezes, para o seu desgaste.

As falas demonstram, também, a dificuldade da mãe em conciliar as atividades profissionais quando os filhos são pequenos, em função da separação da criança por acreditar que sua presença é fundamental para o seu desenvolvimento.

As mulheres que trabalham fora de casa também trabalham dentro de casa. Quando há filhos envolvidos, o estresse associado com o trabalho pode ser ampliado; ainda assim, um número sempre crescente de mulheres com filhos pequenos ingressam na força de trabalho (GREENBERG, 2002).

Algumas das principais áreas de conflito em casa/no trabalho que podem levar ao estresse excessivo são ( WARREN;TOLL, 1998):

- sentir-se culpado por não estar em casa para cuidar das crianças;

- ressentimento por não ficar tempo suficiente com a família;

-ausência de vida social em virtude de horas de trabalho extremamente longas;

-exigências dos parentes dependentes em conflito com as responsabilidades do trabalho;

-não ganhar o suficiente para cobrir os gastos ou para satisfazer a um estilo de vida desejável;

-esperar satisfazer as duas funções, em casa e no trabalho, perfeitamente.

A National Association of Working Women conduziu um estudo sobre o estresse vivido por mulheres que trabalham e observou que $62 \%$ das mulheres descreviam seus empregos como "um pouco estressantes" e 33\% descreviam seus empregos como "muito estressantes". As mulheres na faixa etária dos 30 anos descreviam mais seu trabalho como "muito estressantes" se comparado com outros grupos etários ( GREENBERG, 2002).

Em nosso estudo, embora os trabalhadores do sexo masculino estivessem em menor proporção (13,5\%), também demonstraram desconforto e insatisfação relacionados à sobrecarga de trabalho e suas conseqüências na vida familiar. A sua presença como pai, companheiro ou até mesmo de filho, contribui 
significantemente no equilíbrio emocional da família. Há necessidade dos homens se adequarem para as novas exigências na relação trabalho/família.

"Apesar de eu não conseguir fazer mais nada na minha vida pessoal durante esse horário das 8 às 17 horas, tudo bem, a gente vai levando...conta com a ajuda de outras pessoas"(MED- Equipe 5).

"[...] Agora eu estou pedindo diminuição da carga horária, porque eu gosto de programação com a família, mas eu não tenho condições de ficar nove horas aqui..." (MÉD- Equipe 2).

Se maneiras novas, flexíveis puderem ser encontradas para gerenciar uma harmonia razoável entre o trabalho e a vida familiar, então uma grande área de estresse poderá ser reduzida (WARREN;TOLL, 1998).

É preciso proteger a família contra as influências negativas do trabalho, para que se tenha em casa, um ambiente de recuperação emocional, de apoio e encorajamento. Famílias bem-sucedidas são capazes de suprir as necessidades emocionais de seus membros diante de desafios e agressões da sociedade (MENEZES, 2005).

[...]Conciliar as atividades daqui e a família...é aquela coisa né, é aquela correria...eu acho que você vai levando..." (ENF- Equipe 5).

"[...] Eu acho que de um modo geral, eu acho que eu consigo dividir...poque o fato de você trabalhar fora não quer dizer que tudo que corre fora é 100\% bom. Então quando surge problemas aí esse tempo fica mais difícil" (MED- Equipe 4).

“[...] A vantagem minha é que eu moro pertinho. A vantagem da gente é essa, não precisa pegar ônibus, nem nada, então eu moro aqui pertinho. Só que é bem corrido! É bem corrido..." (ACS- Equipe 2).

Os relatos mostram que os profissionais reconhecem que existem muitas atividades com relação ao trabalho, mas que isto não os desvincula da responsabilidade com a casa e os filhos. Em algumas situações essas podem ser compartilhadas com os companheiros.

Deve-se estar ciente de que não é muito inteligente deixar de lado a família e apenas priorizar o trabalho, para não comprometer de forma grave o futuro de sua família. O equilíbrio é fundamental (MENEZES, 2005). 
Se analisarmos nossas vidas como um todo, teremos uma chance melhor de preencher nosso potencial geral e manter o equilíbrio de atividade que pode nos manter ajustados ao estresse ( WARREN;TOLL, 1998).

Recursos da unidade: a)"Tem falta de recursos humanos... a gente tem pouquíssimos funcionários" (ENF- Equipe 6)

As condições de riscos psicossociais identificadas na literatura e que podem estar relacionadas a esta unidade temática são as elevadas demandas e recursos insuficientes (KASL, 1992).

Ao analisarmos as entrevistas, identificamos como riscos psicossociais no trabalho das Equipes de Saúde da Família, os recursos humanos e materiais insuficientes para as atividades deste modelo de assistência. Estes poderiam estar causando desgaste físico e mental nos trabalhadores.

A estratégia da atenção básica como eixo reorganizador do sistema de saúde brasileiro trouxe à tona uma série de problemas, tradicionalmente classificados como do campo dos recursos humanos. Por inúmeras razões, as intervenções neste campo são mais complexas e frutificam mais a médio e longo prazos (BRASIL, 2002).

Os trabalhadores de nossa pesquisa, especialmente médicos e enfermeiros, pela multiplicidade de tarefas que devem executar, expressam a falta de recursos humanos, e muitas vezes, se sentem sobrecarregados para a dinâmica do processo de trabalho no PSF.

Verificamos que, embora haja diferença entre o reconhecimento da falta de recursos humanos por parte dos médicos e demais membros da equipe, a presença deste risco é levantada nos discursos de mais de $50 \%$ de todas as categorias profissonais.

É crescente o consenso entre gestores e trabalhadores do SUS, em todas as esferas de governo, que a formação, o desempenho e a gestão dos recursos humanos afetam a qualidade dos serviços prestados e o grau de satisfação dos usuários (MAZON; TREVIZAN, 2000).

Os recursos humanos representam a chave fundamental para alavancar uma boa gestão de saúde, mas acompanhada do sentimento de que apenas 
pequena parte dos problemas existentes neste campo é suscetível de resolução, por meio de iniciativas que dependem das decisões dos gestores e dos esforços ou da dedicação dos trabalhadores (NOGUEIRA, 2002).

A expansão do Programa de Saúde da Família tem sido notável. São aproximadamente 15.201 equipes atuando em 4 mil cidades, ou seja, $70 \%$ dos municípios brasileiros realizando atendimento gratuito a quase 50 milhões de habitantes-30\% da população do país. Entretando, o processo de consolidação deste modelo de assistência enfrenta dificuldades no que se refere à ausência, insuficiência e qualidade de recursos humanos em alguns municípios brasileiros (STELLA, 2002). Muitos fatores podem estar contribuindo para esse fato, dentre eles a formação e a distribuição dos profissionais.

No PSF, a Equipe de Saúde da Família é a unidade produtora dos serviços de saúde, em que cada profissional executa um dado conjunto de ações, em separado, porém buscando, constantemente, articulá-las às ações realizadas pelos demais agentes. Cada profissional da equipe responde pelas ações que executa, e ao mesmo tempo em um âmbito de co-responsabilidade, pelo conjunto de intervenções realizadas pela equipe (BRASIL, 1998). Para tal, faz-se necessário um número suficiente de trabalhadores a fim de executarem todas as suas ações com qualidade.

O número insuficiente de profissionais que compõem as equipes de Saúde da Família se reflete nos discursos dos trabalhadores:

"Nós estamos com um problema na unidade básica atual de falta de médicos. Nós temos um clínico geral para 12 mil pessoas, que é a área de abrangência da UBS, a minha área de abrangência tem 4.400 pessoas. Então dessas 12.000 , cerca de 8.000 fica para o outro colega . Devido a essa carência de profissional, há uma necessidade grande, um fluxo de pacientes, de atendimentos de pacientes. Isso dificulta um pouco a gente realizar as outras tarefas do PSF como visita domiciliar, reuniões de agente de saúde, cursos para gestantes, para hipertensos e cursos para diabéticos (MED -Equipe 6)

"Existe dificuldade... eu acho que tem pouco médico disponível, assim para trabalhar, disponível. Quando entra um de férias, então não tem médico no lugar dele [...] eu acho que deveria ter mais médicos na equipe de saúde, mais enfermeiro..." (ACS- Equipe 6) 
"O serviço do PSF é muito gratificante. Quando a enfermeira e o médico vão na casa , o paciente fica muito agradecido... só que deveria ter mais médico.. A minha microárea... eu tem muito problema e eu tenho um relacionamento muito bom com os pacientes...."(ACS- Equipe 5).

Os discursos dos entrevistados expressam que o número de profissionais disponíveis para a equipe não corresponde à necessidade da demanda, impedindo, muitas vezes, a realização de todas as atividades planejadas e necessárias para a assistência da população.

Verifica-se, portanto, que com a implantação do Programa de Saúde da Família surgiram problemas como o número insuficiente dos trabalhadores para atuarem nesta área. Este fato pode ter ocorrido pela forma como o Programa foi implantado, sendo as equipes instaladas em Unidades de atendimento mistas, sem a redistribuição adequada dos trabalhadores para o atendimento deste modelo de assistência.

Este fato se reitera na fala dos entrevistados:

“...A gente teria que ter uma equipe assim, teríamos que ser quatro disponíveis para o programa e isso não acontece, nós somos...Nós dividimos em dois grupos. Dois atuam no Programa de Saúde da Família durante um período e dois servem a unidade no modelo que é convencional, então nós temos essa dificuldade, e não podemos contar com os quatro auxiliares ao mesmo tempo, né.. nós temos que dividir porque a unidade tem a sua função lá fora, então em função disso nós temos dificuldade" (AUX-Equipe 1)

"[...] Eu tenho duas auxiliares de enfermagem que, como eu, são voltadas na área e trabalha aqui...eu não posso contar com elas de maneira alguma , eu não posso tirar elas da escala, não podem ir fazer uma visita comigo, nada...porque de manhã o plantão é meu, sozinha na unidade, e elas também trabalham oito horas para a unidade, não foi colocado ninguém a mais como não foi uma enfermeira a mais. Eles implantaram o PSF aqui, mas não deram recursos humanos necessários...Não aumentaram o número de funcionários" (ENF- Equipe 4).

Sabemos que o número insuficiente de trabalhadores e o elevado número de tarefas contribuem para aumentar os níveis de absenteísmo, já que ocorre a sobrecarga e insatisfação, promovendo conseqüentemente a queda na qualidade dos serviços prestados (MEIRELLES, 1997). 
Este novo modelo de assistência propõe o desafio contínuo em garantir ações e serviços de saúde de qualidade à população como estratégia de reorientação da atenção básica e do modelo de atenção à saúde no país, pela valorização do vínculo e do compromisso entre equipe de saúde, indivíduos e comunidade. O direcionamento que a estratégia de Saúde da Família imprime na construção de um novo modelo de atenção, nos leva a um detalhamento do trabalho realizado pelas Equipes de Saúde da Família para a identificação das questões e desafios relacionados com recursos humanos, bem como para a proposição de intervenções e ações. São características deste trabalho (SEIXAS, 2002):

- serviço em tempo integral, permitindo mais dedicação e responsabilização com a população atendida, exigindo novas competências tanto para o cuidado físico integral e geral, como para a abordagem psico-afetiva;

- incorporação de um novo ator na equipe de saúde, em relação ao qual há especialidades de inserção: agente comunitário de saúde que aprofunda o vínculo e a capacidade de conhecimento e diálogo com aquela comunidade;

- mecanismos e valores de remuneração diferenciados para os trabalhadores, permitindo mais compromisso com o trabalho, mas exigindo ajustes e novas modalidades de vinculação;

- responsabilidade da equipe por determinada população, residente em território definido, aprofundando o comprometimento e exigindo competências relativas ao planejamento do trabalho em equipe, um dos pilares da transformação do modelo de assistência, de garantia da assistência integral, promovendo a desfragmentação do trabalho.

Ao romper com a fragmentação da atenção pelos diferentes agentes de trabalho, criam-se áreas de atuação comuns que são caracterizadas pela complementariedade de competências e compartilhamento de responsabilidades pelos profissionais (SEIXAS, 2002).

Assim, amplia-se o escopo de atuação, o que cria a necessidade de redefinição das funções e papéis tradicionais das profissões, que devem manter suas especialidades, porém reordenando o trabalho (SEIXAS, 2002).

Nesta nova estratégia de assistência, o PSF, onde se preconiza um movimento de reordenação do modelo assistencial, várias atividades são propostas pelo MS, fora do âmbito da Unidade de Saúde, com o objetivo de identificar as reais 
necessidades da população adscrita. Por exemplo, o cadastramento das famílias, visitas domiciliárias, curativos em domicílio, entre outras, que devem ser realizados pelos membros das equipes de Saúde da Família. Com o número precário de trabalhadores atuando nas Equipes de Saúde da Família, todas estas atividades ficam extremamente prejudicadas, gerando dificuldade na identificação dos problemas da realidade sanitária, como podemos verificar através das "falas" dos entrevistados.

"[...] Difícil é o pessoal, né, para estar saindo da unidade para estar fazendo... porque tem o trabalho da unidade..também tem, né. Então é um pouco difícil..."(AUX-Equipe 6).

"Eu sou do PSF, mas nunca dá para sair para fazer um curativo em domicílio, porque não tem funcionário...Eu fico mais... eu tenho mais trabalho com o posto e eu não participo quase de lá.......] Não colocou ninguém no meu lugar, é complicado. Por exemplo: -Quando eu tenho que ir nas casas, fazer um curativo, uma visita, não dá para eu ir porque falta profissional e eu não posso sair" (AUX Equipe 4).

"Tem falta de recursos humanos, a gente tem pouquíssimos funcionários. Se você precisa fazer alguma visita domiciliária e a auxiliar tem que estar cobrindo a unidade, o serviço da unidade. E ela não pode estar indo fazer a visita, então não será feita, porque desfalca a unidade. [...] Se eu saio da unidade eu vou ficar preocupada, porque vai ficar descoberta de enfermeira" (ENF- Equipe 6).

O déficit de pessoal para atender às necessidades da população sobrecarrega alguns profissionais, gerando sentimento de frustração nestes trabalhadores, como observamos nos relatos a seguir:

"[...] A gente está com um déficit de funcionário, tem funcionário de férias, funcionário de licença-gestante e tem funcionário...então a gente fica sobrecarregada mesmo na questão do serviço que a gente quer fazer e tem uma linha de trabalho que a gente vem desenvolvendo, então a gente se sente frustrada" (AUX- Equipe 2).

"[...] Agentes Comunitários de Saúde estão faltando... nós somos em doze, nós estamos somente em oito, está faltando quatro... tem área descoberta, que às vezes a gente deixa de fazer o serviço da gente para ir cobrir aquela área...eu acabo fazendo duas áreas" (ACS- Equipe 3). 
É importante ressaltar que, para a quantificação do número exato de recursos humanos, é necessário conhecer algumas características do dimensionamento de pessoal, quais sejam: as características do local de trabalho, os equipamentos, a planta física e todas as exigências para calcular o número de profissionais adequados para a assistência com qualidade. O dimensionamento de recursos humanos, em qualquer organização, tem sido considerado um desafio. Esses recursos são os mais complexos da organização, e os demais recursos exigem a sua presença, para que possam ser utilizados (KURCGANT, 1991).

Conhecedores da proposta do PSF e da realidade sanitária, entendemos que o dimensionamento de pessoal para atuar nas equipes deve ser definido a partir de uma análise da complexidade da assistência a ser prestada aos usuários de cada área de abrangência.

Sabemos o quanto é difícil, mesmo tendo o conhecimento de dimensionamento de pessoal, quantificar quantos cuidados serão necessários para atender à população de uma determinada área.

A exigência de alguns usuários é diferente de outros e, nesta situação, consideramos que um número maior de trabalhadores, bem preparados para atuar nesta área, proporciona menor ansiedade, com a possibilidade de assistir, de forma qualificada, os clientes, em quaisquer situações.

Recursos da unidade: b)“O que é desgastante, às vezes, é a falta de material"(AUX-Equipe 5).

Para a qualidade da assistência diante das mudanças que vêm ocorrendo no setor saúde, é importante se preocupar tanto com a questão dos Recursos Humanos quanto dos recursos materiais disponíveis.

Sabe-se que no setor público existem falta de material e pouco controle. Os profissionais têm que lidar com essas questões cotidianamente, pois as conseqüências recaem sobre a unidade de trabalho, não descartando a possibilidade de causar danos a clientes e trabalhadores.

A escassez com a qual se trabalha nos serviços de saúde vai desde os recursos materiais (material permanente e de consumo) até a insatisfação e desgaste dos profissionais. 
"A gente está numa Unidade Básica de Saúde, a gente não tem um eletrocardiograma, a gente não tem um aparelho de $R X$, você não tem como fazer determinados exames no paciente... A dificuldade maior é com o paciente grave... Então, por exemplo, você vai controlar um paciente que está com descompensação diabética, você vai hidratar o paciente como, você não sabe como está o potássio dele. Então você não tem recursos" (MED- Equipe 2).

"Não tem material...Os trabalhos que a gente fez, por exemplo, os educativos, nós saímos à caça, inclusive de material...Muitas vezes a gente pagou do próprio bolso. A gente costuma priorizar o que a gente consegue, material alternativo para artesanato, para reciclar, essas coisas. Mas tudo, tudo a gente sai meio que à caça" ( MED- Equipe 4).

A falta de recursos materiais foi levantada por todas as categorias profissionais, sendo os $\mathrm{ACS}_{\mathrm{s}}$ unânimes em expressar, nos seus discursos, tal situação (Quadro VI).

Verifica-se que alguns trabalhadores utilizam recursos materiais próprios para implementar 0 trabalho. Mas, percebe-se também 0 desgaste como conseqüência da falta de recursos nos serviços.

"O que é desgastante às vezes é a falta de material mesmo, né, e assim a falta de material mesmo, né, e assim a falta de resolutividade para os casos" (Aux-Equipe5).

"A gente tem que improvisar e fazer o máximo que a gente pode, né. Então é tudo improvisar, e fazer o máximo que a gente pode, né. Então é tudo improvisado, porque falta muita coisa. Você sempre esbarra né, você consegue aqui e esbarra ali... e às vezes a gente fica estressado" (AUX -Equipe3).

"A gente não ganha um óculos, a gente não ganha uma caneta, não ganha uma borracha, uniforme, roupa, sapato... A gente não ganha nada... é tudo do nosso bolso. A gente chega na casa da pessoa você encontra situações dificílimas, não tem um incentivo para a gente trazer de volta os problemas para resolver... Você fica perdida, dá uma angústia... aqui no posto, os agentes de saúde estão todos estressados..." (ACS- Equipe 3).

É importante ressaltar que a falta de materiais pode deixar o trabalhador angustiado e estressado e que mesmo com estes recursos insuficientes nos serviços de saúde é necessário fazer as coisas acontecerem. Se há compromisso, vínculo, aquilo que se pode fazer, tem que ser feito, no mínimo, com qualidade, e os profissionais se apresentam como elementos detentores de competência para que o trabalho aconteça. 
"[...] Então assim, você tem que ir se virando, bastante... Eu acho até que a gente faz muito com essa falta de condição, com essa falta de tempo, com essa falta de tanta coisa..."(ENF.-Equipe 5).

De acordo com os entrevistados, há insatisfação em relação às condições de recursos oferecidas para a realização do trabalho. Esta insatisfação pode gerar insegurança, rebaixamento da auto-estima e uma gama de sentimentos desprazerosos (medo, tristeza..) que têm como conseqüência uma baixa produtividade, alta taxa de rotatividade no emprego, absenteísmo, erros na execução das atividades e propensão a acidentes no ambiente de trabalho (MACEDO, 2005).

A satisfação do trabalhador está ligada à identificação com a atividade. "É preciso se reconhecer naquilo que faz, imprimir uma marca. Quanto maior for a relação de afeto com o trabalho, menores as chances da pessoa adoecer e maiores são as chances de garantia de produtividade", afirma o pesquisador/doutor em ergonomia pela École Pratique des Hautes, na França (FERREIRA, 2005).

Diante de carências e dificuldades, os profissionais devem acreditar nas possibilidades de mudanças no setor saúde, para que possam oferecer melhor assistência à população, mais humanizada, visando a melhorias na qualidade de vida dos usuários do Sistema.

\subsection{Estratégias de controle dos riscos psicossociais}

A análise dos discursos dos entrevistados possibilitou a construção de unidades temáticas relacionadas às estratégias de gerenciamento dos riscos psicossociais, segundo a freqüência de sua utilização por cada categoria profissional (Quadro 7). 
Quadro 7- Distribuição das Unidades Temáticas relacionadas às estratégias de gerenciamento dos riscos psicossociais e sua freqüência nas falas de cada categoria profissional, Ribeirão Preto, 2005.

$\begin{array}{llccccr}\begin{array}{l}\text { Unidades } \\ \text { Temáticas }\end{array} & \begin{array}{l}\text { Categoria } \\ \text { Profissional }\end{array} & \text { Méd. } & \text { Enf. } & \begin{array}{l}\text { Auxil. } \\ \text { Entratégias }\end{array} & \text { ACs } & \text { Total } \\ & \begin{array}{l}\text { Gerenciamento } \\ \text { Exercício Físico }\end{array} & 4 & 2 & 1 & 4 & 11 \\ \text { Estratégias } & \text { Cinema } & 1 & 1 & - & - & 2 \\ & \text { Música } & - & 1 & - & 1 & 2 \\ & \text { Religião } & - & 1 & 4 & 3 & 8 \\ \text { Estratégias } & \text { Leitura } & - & 1 & 2 & 1 & 4 \\ \text { da Equipe } & \text { Reuniões semanais } & 6 & 6 & 6 & 6 & 24\end{array}$

As estratégias para o controle desses riscos podem ser estabelecidas pelo trabalhador, bem como, pela instituição, as quais estarão nas unidades temáticas que passaremos a descrever.

De acordo com o quadro 7, verificamos que os trabalhadores utilizam-se de várias estratégias individuais para aliviar os efeitos desgastantes dos riscos presentes no trabalho. Cabe salientar que o exercício físico foi a única estratégia utilizada por todas as categorias profissionais, totalizando $45 \%$ dos sujeitos.

Em relação a estratégias da equipe, verificamos que todos os trabalhadores participam das reuniões semanais e as consideram como uma forma de alívio das tensões encontradas no cotidiano do trabalho.

Estratégias individuais: "Eu procuro ir andando pra casa, fazer caminhada, pra poder ir relaxando e voltar relaxada..." (ACS- Equipe 3).

O trabalho desenvolvido pelas Equipes de Saúde da Família envolve estressores psicossociais relacionados ao trabalho. Estes estressores psicossociais se referem, "a interação com o meio do ambiente de trabalho, condições organizacionais e habilidades do trabalhador, necessidades, cultura e causas extratrabalho pessoais", que podem influenciar a saúde, o desempenho e a satisfação no trabalho (INTERNATIONAL LABOUR OFFICE, 1984). 
Após a identificação de estressores no ambiente laboral, torna-se necessária a elaboração de estratégias para o seu controle a fim de evitar danos à saúde dos trabalhadores.

Os discursos revelam algumas estratégias pessoais utilizadas pelos trabalhadores para amenizar os efeitos desgastantes do seu trabalho.

"Hoje, para mim, na minha idade fisicamente eu tenho um limite, maior do que eu tinha antes..e eu sei que devo me cuidar também, já que passo para as pessoas...e eu tenho..., eu faço ginástica, tenho alguns cuidados, faço drenagem linfática uma vez por semana porque me faz bem..." (MED- Equipe 4).

"Eu estava me desgastando! Eu não conseguia mais me aturar! É uma cobrança em cima da outra e você nunca está bem, você está sempre no regular... porque você malha, malha, malha e o paciente não faz. Então eu acho que isso desgasta e eu acabo ficando tensa. E eu fui buscar a saída em um curso de auto-conhecimento, e eu melhorei muito..." (ENF - Equipe 2).

"Na minha vida pessoal, faço uma caminhada, nado um pouco. Em termos de lazer, eu vou ao cinema é isso, eu vou ao cinema" (MED- Equipe 5).

“Eu participo muito da comunidade. Então isso ajuda bastante também,... eu tenho um grupo de amigos da igreja que ajuda bastante também" (ACS-Equipe 1).

Os discursos revelam que as estratégias utilizadas pelos trabalhadores, como atividade física, repouso, lazer, são de caráter pessoal, e indicam a busca do bem-estar emocional e atitudes adequadas para o enfrentamento desta realidade. Estas estratégias dependem única e exclusivamente do trabalhador para a sua realização.

A carga horária, longas horas de trabalho, o número de atividades desenvolvidas com a comunidade interferem decisivamente no tempo dedicado a si próprio, como aparece nos discursos dos entrevistados.

"Eu faço hidroginástica, quando eu consigo assim adaptar meu horário direitinho eu faço academia, faço hidroginástica, quando eu não consigo fazer nada disso no horário certo eu faço caminhada, ouço música, leio, com os meus recursos" (MEDEquipe 1).

“[...] Então a minha rotina acaba bem tarde, mas pelo menos eu estou conseguindo fazer a minha hidro, e está sendo bom, está sendo bom pra mim. Eu sempre gostei de atividade física, mas eu tinha parado" (ENF- Equipe 5). 
"Eu faço caminhada à tarde, depois do horário, porque a gente encerra às cinco horas e às seis horas da tarde eu faço caminhada. Então eu vou sozinha, aí a gente vai pensando... podia ter feito isso, podia ter feito aquilo...não, fiz isso deu certo, e tal... então eu faço caminhada pra aliviar" (ACS- Equipe 4).

Através das "falas", verificamos que o trabalho situa-se em primeiro plano na vida desses profissionais e somente quando a carga horária permite, é que eles vão em busca de estratégias para aliviar as tensões do ambiente laboral.

A complexidade do programa exige que os profissionais tenham clareza de suas diferentes dimensões: interesses e visões sobre os modelos de saúde, especialmente do PSF; visões sobre trabalho em equipe e compreensão da dinâmica das relações interpessoais entre equipe e comunidade. É preciso competência para intervir na trágica realidade sanitária brasileira, para que não assuma uma atitude acrítica e acomodada, pela insegurança em situar-se e atuar no Programa de Saúde da Família. A falta destes conhecimentos e habilidades deve provocar desgaste e insatisfação no trabalho.

Como vimos anteriormente, os trabalhadores reconhecem a necessidade do aprimoramento técnico-científico para lidar com as situações que se apresentam no cotidiano do trabalho, mas consideram que as estratégias utilizadas para aliviar as tensões favorecem esquecer os problemas e/ou dificuldades com os quais se deparam.

"Eu procuro ir andando pra casa, fazer caminhada, pra poder ir relaxando e voltar relaxada... então em casa a gente procura escutar música, eu gosto muito de música e gosto muito de ler. Então, o meu relaxamento, se eu não ler de noite pra poder dar uma relaxada eu não consigo nem dormir, porque aí só eu fico pensando nos problemas que estão acontecendo..." (ACS- Equipe 3).

"O que eu procuro fazer é a hora que saio daqui....eu esqueço...acabou o serviço, aí eu vou pra minha vida. Então eu procuro fazer as coisas que eu gosto, ouvir música, vou ao cinema, faço caminhada" (ENF-Equipe 3). 
As entrevistas revelam que os trabalhadores utilizam estratégias de gerencimento ou controle das situações desgastantes após sofrerem o desgaste físico e/ou mental. Para alguns trabalhadores, a rotina intensa do trabalho faz com que ele procure uma ajuda somente quando se sente completamente desgastado.

“Eu faço tricô...isso virou um hobby...agora quando eu estou estressada...eu faço pintura, artesanato queria aprender para ensinar o pessoal, mas acabou virando a minha terapia" (ENF -Equipe 4).

"Quando eu estou muito tensa, eu vou andar no supermercado ou ler... eu gosto muito de ler romance, no trabalho mesmo, quando a gente está muito cansada numa escala, a gente pede pra chefe...aí ela tenta trocar a gente, na medida do possível... às vezes eu estou tão cansada que eu não consigo fazer nada." (AUXEquipe 2).

"De vez em quando eu fecho tudo, me tranco no quarto, dou uma relaxada lá, faço alguns exercícios de relaxamento mesmo" (AUX- Equipe 6).

A complexidade das atividades desenvolvidas neste programa, a escassez de recursos humanos e materiais não impedem os trabalhadores de procurarem descobrir novas formas de enfrentamento das situações adversas.

"Minha distração que alivia um pouco meu estresse são os cultos mesmo, a parte espiritual, a parte física não dá tempo"(AUX- Equipe 1).

“Então eu ajudo a entidade, que é uma ONG (Organização não - governamental). Eu vejo que naquela organização, assim... dá para extravasar um pouco do que a gente não consegue fazer aqui. A satisfação de você ver o que fez lá, compensa tudo o que você tentou aqui e não conseguiu" (AUX-Equipe 5).

No momento em que os profissionais das Equipes de Saúde da Família fazem o máximo para atender às múltiplas exigências do trabalho altamente responsável, se deparando com situações desgastantes no dia-a-dia, enfrentam um desequilíbrio biológico que pode vir a afetar não somente a eles como pessoa, mas também a comunidade. Portanto, faz-se necessário que este trabalhador seja preparado para enfrentar esta realidade além de receber um suporte emocional adequado. 
Um passo importante no gerenciamento do estresse é compreender nossas necessidades pessoais e profissionais em cada estágio de nossas vidas e reconhecer quando elas não estão sendo satisfeitas.

"Eu acho que a grande vantagem daqui é isso que a gente é quem fecha as portas, você tranca a porta e vai embora, acabou! É trabalhar mesmo no dia-a-dia com as situações que acontecem aqui" (ENF-Equipe 3).

Quando as pessoas estão perturbadas por algo que as está preocupando, isso as torna incapazes de operar adequadamente no trabalho.

"Eu chego em casa e às vezes choro muito! Tem dia que eu nem como, porque tem coisa que você encontra... tem coisa que dá pra você tirar de letra, mas tem coisa que te emociona muito. A gente só trabalha pra eles, vai pra casa, trabalha pra eles, se eu tenho um problema grave na minha área, aí eu trago e discuto aqui na unidade. Você encontra a pessoa numa situação muito difícil, aí é difícil para você. Aí eu acho que é só chorando mesmo para aliviar. A gente se apega muito nas pessoas.." (ACS- Equipe 2).

Esta fala retrata que, além do exercício físico, da leitura, religião, os trabalhadores também utilizam estratégias como o "choro" para aliviar as tensões do trabalho.

Estratégias da equipe: "[...] Temos as nossas reuniões de equipe, onde a gente coloca as nossas alegrias, as nossas frustrações, as dificuldades que a gente está encontrando "(ACS-Equipe 5).

De acordo com os discursos anteriores, podemos dizer que os trabalhadores encontram várias maneiras para aliviar as tensões do ambiente de trabalho. Mas não podemos esquecer que o local de trabalho pode ser uma fonte de ajuda ao trabalhador. A oferta de ajuda profissional é sempre bem-vinda.

Além das estratégias individuais, os trabalhadores utilizam estratégias coletivas como forma de aliviar as tensões do ambiente de trabalho, bem como 
melhorar o relacionamento entre os membros da equipe, que são as reuniões semanais de discussões de casos.

Existem reuniões na instituição...essas reuniões, na realidade, elas são feitas pra gente tá buscando os nomes, os problemas, é mais assim uma troca entre as agentes comunitárias, equipe de enfermagem e a equipe do PSF da unidade. Então é uma troca de informação entre agente comunitária e a equipe do PSF, pra gente estar buscando essas informações e priorizando quais são as visitas mais importantes pra gente.." (AUX-Equipe 1).

"A gente coloca as dificuldades em reunião... os casos de dificuldade que a gente encontra na comunidade, a família que precisa de uma visita de enfermeiro, que precisa de uma visita do médico, é colocado tudo na reunião de segunda-feira à tarde" (ACS-Equipe 1)

"A gente tem reunião semanal... aí a gente conversa de tudo, casos, agendar coisas, férias, informes, tudo... é uma reunião onde se fala de tudo. Se alguém está precisando desabafar alguma coisa é ali, é tudo ali. São umas duas horas de reunião" (ENF - Equipe 5).

"[...] temos as nossas reuniões de equipe, onde a gente coloca as nossas alegrias, as nossas frustrações, as dificuldades que a gente está encontrando. Então assim, é um modo de ajudar" (ACS- Equipe 5).

Geralmente estas reuniões são coordenadas por um membro da equipe, e todos expõem seus problemas e dificuldades.

Além desses encontros, não foi citado nos discursos dos trabalhadores outro tipo de ajuda oferecida pela instituição a que pertencem estas equipes e observa-se nas suas falas a necessidade de um suporte para enfrentar as situações no coditiano do trabalho.

"[...]A instituição não oferece nada, inclusive foi um pedido nosso. É muito difícil você trabalhar porque a gente tem agente comunitário de saúde que tem primeiro grau, tem agente que é mais...É muito difícil você lidar com esse grupo... Ás vezes o próprio grupo de agentes entra numas brigas entre eles, e pedimos uma assessoria, mas até agora não conseguimos " (ENF- Equipe 1). 
"Nós carregamos problemas de todo mundo... você vai numa casa tem problema... na outra tem problema..e isso prejudica a gente, porque mesmo que você não queira você se envolve com o problema das pessoas. Deveria ter um apoio nisso, pra gente. Pra gente poder lidar com isso...um suporte. A gente sente bastante por ele... o cliente passa a ser uma pessoa muito íntima."(ACS- Equipe 3)

A menos que a organização tome uma posição clara com relação à questão do gerenciamento do estresse, quaisquer ações individuais para tentar resolver o problema terão efeito limitado, particularmente dadas as inibições com relação a tratar do assunto (WARREN;TOLL, 1998).

Weimberg e Creed (2000) propõem um enfoque baseado em evidências para melhorar o ambiente de trabalho que deveria ter dois componentes:

- um serviço de assistência individual ao funcionário, ou algum outro tratamento psicológico para assegurar a prevenção e o tratamento de doenças depressivas.

- suporte àquele que tem conflito entre suas funções clínicas e gerenciais fornecido pela organização.

Era muito freqüente no passado o gerenciamento de situações estressantes ou o controle do estresse ser considerado de responsabilidade do indivíduo. Entretanto, cada vez mais as organizações estão compreendendo que gerenciar o estresse pode trazer um lucro para elas próprias bem como para seus funcionários, e dessa forma caminham em direção a manejar o estresse (WARREN;TOLL, 1998).

Peterson, Dunnagan (1998) abordam o impacto de programas de promoção da saúde no local de trabalho sobre a satisfação. Os autores ressaltam que mudanças na organização do trabalho e melhoria do ambiente psicossocial incrementam substancialmente tanto os impactos sobre a satisfação no trabalho como os indicadores de saúde dos trabalhadores.

Pesquisas demonstram os benefícios psicológicos e físicos do suporte social e mostram como os profissionais com este suporte trabalham melhor psicologicamente os eventos estressantes e reduzem o risco de mortalidade por doenças específicas (HOUSE; LANDIS; UMBERSON, 1988 apud TAYLOR, 1991, p. 63) ${ }^{3}$.

\footnotetext{
3 TAYLOR, S.E. Health Psicology. In: LAZARUS, R.S.; MONAT, A. (Ed). Stress and coping. $3^{\mathrm{a}}$ ed, New York, 1991, cap.4, p62-80.
} 
Programas específicos de gerenciamento do estresse devem ser criados pelos serviços para cada situação. Os programas podem ser voltados para o meio ambiente, ligados à motivação e ao desenvolvimento profissional, bem como diretamente relacionados à performance do organismo do trabalhador.

As organizações de trabalho devem ter o objetivo de restaurar o equilíbrio e funcionamento psicobiológico do trabalhador, para pelo menos amenizar problemas de estresse presentes. 
6 OS RISCOS PSICOSSOCIAIS E AS ESTRATÉGIAS DE GERENCIMENTO NO TRABALHO DAS EQUIPES DE SAÚDE DA FAMÍLIA 
O conceito de riscos psicossociais, adotado neste trabalho, os pressupõe como aspectos de interação entre o trabalho e seu ambiente, conteúdo do trabalho, condições organizacionais e habilidades do trabalhador, necessidades, cultura, causas extratrabalho, pessoais e que podem, por meio de percepções e experiência, influenciar a saúde, o desempenho e a satisfação no trabalho (INTERNATIONAL LABOUR OFFICE, 1984).

Alguns autores descrevem que os riscos psicossociais presentes no trabalho e que podem levar ao estresse, podem ser classsificados em diversas categorias como: cultura e função organizacional, função na organização, desenvolvimento de carreira, decisão e controle, relacionamento interpessoal no trabalho, interface trabalho-casa, ambiente de trabalho e equipamento de trabalho, planejamento das tarefas, cargas e local de trabalho e esquema de trabalho (COX et al., 2000).

Nas situações do trabalho dos profissionais em estudo, foram identificados riscos psicossociais como: falta de preparo e capacitação, sobrecarga de papéis, conflito interpessoal no trabalho em equipe, longas horas de trabalho, conflito na relação trabalho/família e recursos humanos e materiais insuficientes.

Atendo-nos para as condições de trabalho nas unidades em estudo, especificamente ao contexto do trabalho, verificamos que um dos riscos psicossociais está relacionado a capacitação ou preparo dos trabalhadores para atuar no PSF. Os trabalhadores sentem-se despreparados e relatam dificuldades para enfrentar a diversidade da realidade sanitária, levantando a necessidade de aprimoramento contínuo nesta área.

Observa-se que os profissionais que atuam neste programa foram graduados em cursos que utilizam currículos firmados no paradigma curativo e fragmentado da saúde, em que são valorizadas as especialidades e não a compreensão do ser humano integralmente. No PSF, é exigido deste profissional um conhecimento generalista não existente em sua formação.

Mendes (1996) se refere à estratégia de saúde da família como parte das propostas inovadoras com vistas à formulação de novas práticas de saúde. Consiste no paradigma da produção social da saúde, por intermédio do desenvolvimento de ações direcionadas às famílias e à comunidade, de forma contínua, personalizada e ativa. Enfatiza a promoção e prevenção, não se descuida 
do aspecto curativo reabilitador; com alta resolutividade, baixos custos diretos e indiretos, sejam econômicos e sociais e privilegia a intersetorialidade.

Para atuar nesse novo modelo assistencial, é necessário que estes profissionais tenham um perfil mínimo para um trabalho em saúde compartilhado, humanizado, com responsabilização e vínculo com a comunidade, reconhecendo a saúde como direito de cidadania. Além disso, a realidade sanitária apresenta problemas cada vez mais complexos, que exigem além de conhecimentos da clínica ampliada, habilidades no relacionamento interpessoal e intersetorial.

A falta de preparo e/ou capacitação é considerada pelos trabalhadores como uma situação angustiante e que dificulta a resolução dos problemas diagnosticados na comunidade, gerando insatisfação no trabalho que, por sua vez, pode levar ao aparecimento de estresse. Então, é considerado um risco psicossocial no âmbito do Programa de Saúde da Família.

Em novembro de 2005, foi lançado pelo Ministério da Saúde em parceria com o Ministério da educação, o Programa Nacional de Reorientação da Formação Profissional em Saúde- PRÓ-SAÚDE, que visa a aproximação entre a formação de graduação no país e as necessidades da atenção básica, que se traduzem pela estratégia de saúde da família. O que se busca é a intervenção no processo formativo para que os programas de graduação possam deslocar o eixo da formação- centrado na assitência individual prestada em unidades especializadaspor outro processo em que a formação esteja sintonizada com as necessidades sociais, e que leve em conta as dimensões sociais, econômicas e culturais da população (BRASIL, 2006).

Notamos que, a partir da implantação do Programa de Saúde da Família, surgem novas exigências de qualidade na execução das tarefas e novas competências do trabalhador.

A deficiência na formação dos profissionais das Equipes de Saúde da Família, deve ser eliminada à medida que as instituições promovam capacitações através de um processo de educação permanente, além de um suporte ou retaguarda para enfrentar as situações presentes no cotidiano do seu trabalho.

Assim, a educação dos profissionais de saúde deve ser entendida como um processo permanente, que se inicia durante a graduação e é mantido na vida profissional mediante o estabelecimento de relações de parceria entre as 
instituições de educação superior, os serviços de saúde, a comunidade, as entidades e outros setores da sociedade civil (BRASIL, 2006)

De acordo com os participantes da pesquisa, verificamos que a instituição responsável promove cursos esporádicos para os trabalhadores que, devido ao volume de atendimento, sobrecarga de papéis, recursos humanos insuficientes nas unidades, ficam indisponibilizados para tal aprimoramento.

Os trabalhadores das Equipes de Saúde da Família, de acordo com o Ministério da Saúde, possuem várias atribuições e, muitas vezes, no âmbito do seu trabalho assumem diversos papéis. É o que podemos verificar em nosso estudo de acordo com os entrevistados, quando relatam a multiplicidade de papéis, ou seja, a responsabilidade por várias tarefas, e este fato se traduz em tensões, insegurança e desmotivação no trabalho, que por sua vez, podem levar o trabalhador a apresentar sintomas de estresse. Assim, esta condição é considerada um risco psicossocial no trabalho destes profissionais.

A gerência do cuidado e da unidade são algumas das responsabilidades extras que alguns membros da equipe assumem.

O gerente deve planejar e controlar a dinâmica do trabalho da equipe, bem como todos os recursos que envolvem a unidade (PENA et al., 2004).

O cargo de gerência é atribuído para os profissionais de nível superior, e em nosso estudo aparece, especificamente, como um dos papéis desempenhados pelas enfermeiras.

Os trabalhadores expressam dificuldades para cumprir todas as tarefas que lhe cabem, considerando esta situação um fator desgastante no trabalho.

$\mathrm{Na}$ vivência dos trabalhadores, a inadaptação entre as aptidões, as necessidades psicológicas do trabalhador e o conteúdo da tarefa traduzem-se por insatisfação ou por sofrimento, ou até mesmo por um estado de ansiedade raramente traduzido em palavras e/ou explicitada pelo próprio trabalhador (DEJOURS, 1992).

Verifica-se que o número intenso e diverso de atividades, a serem desempenhadas pelos profissionais das Equipes de Saúde da Família, está diretamente relacionado ao volume crescente de trabalho nas unidades de saúde, pelo aumento da demanda por estes serviços. 
Os profissionais sentem-se responsáveis pela população de sua área de abrangência e utilizam um ritmo inadequado de trabalho a fim de finalizar todas as atividades preconizadas e/ou necessárias a uma assistência com qualidade.

As longas horas de trabalho aparecem como uma alternativa comum para a realização destas tarefas e, portanto, é uma realidade que não pode ser ignorada, sendo um dos fatores de interferência na relação trabalho-família, bem como, no seu aperfeiçoamento profissional. De acordo com Cox et al. (2000), a sobrecarga de trabalho e os altos níveis de pressão são riscos psicossociais que podem causar estresse no trabalhador.

Conciliar o trabalho e o lar foi expresso pelos participantes da pesquisa como difícil e desgastante. Observa-se sentimento de insatisfação por parte dos trabalhadores com o tempo dedicado aos familiares. Os conflitos nas exigências do trabalho e do lar é uma condição de risco relacionado ao contexto do trabalho que pode levar ao estresse (COX et al., 2000).

Dentro do contexto do trabalho, vale a pena lembrar, como destaca Dejours (1992), que o trabalhador não chega à organização como uma máquina nova. Ele interage continuadamente com sua história passada, uma história pessoal que gera aspirações, desejos, motivações e necessidades psicológicas. Isto confere a cada indivíduo características únicas e pessoais.

Considerando a importância da satisfação no trabalho para a auto-estima de uma pessoa, um indivíduo diante de situações desgastantes e/ou estressantes poderá ter problemas no seu papel familiar, sentindo-se, por exemplo, inseguro quanto a sua contribuição na manutenção da família. A irritabilidade causada pelo estresse ocupacional provavelmente se estenderá à família, gerando relações tensas e conflituosas (LIPP; MALAGRIS, 2001).

É o que observamos, quando os trabalhadores reconhecem que o volume de trabalho intenso e a carga horária elevada provocam desgaste físico e mental, e por sua vez, levam a relações tensas e conflituosas com os familiares.

A implantação do Programa de Saúde da Família levou à necessidade do estabelecimento de equipes multiprofissionais para o alcance dos objetivos deste programa. São diversas categorias profissionais atuando em um mesmo espaço físico, com uma população preestabelecida, gerando formas de interação diversas. Compreendemos que a Saúde da Família pode se abrir para um trabalho com interação social entre os trabalhadores, com maior horizontalidade, possibilitando 
autonomia e criatividade dos agentes e maior integração da equipe (ALMEIDA; MISHIMA, 2001).

Em nosso estudo, os profissionais revelam que o trabalho em equipe é significativo, mas que não houve um preparo adequado para tal aspecto durante a estruturação das equipes. Eles concordam que a falta de capacitação para o trabalho em equipe somada às características do trabalho no PSF geram conflitos entre os trabalhadores, sendo considerado um dos entraves para a organização do processo de trabalho.

A população estudada expressa a existência de um relacionamento conflituoso e desgastante, e reconhece a necessidade de aprender a trabalhar em equipe. Para Cox et al. (2000), o conflito interpessoal no trabalho é um risco psicossocial que pode causar estresse.

As Equipes de Saúde da Família devem responsabilizar-se por um conjunto de problemas bem delimitados, e pelo planejamento e execução de ações a fim de resolvê-los. Portanto, este modelo pressupõe envolvimento da equipe com a população de sua área de abrangência para futuras intervenções na melhoria da saúde desta população. Mas, para que isto ocorra, a população deve compreender o papel deste modelo de atenção e se sentir co-responsável na busca de soluções para os seus problemas.

Em nosso estudo, de acordo com as falas dos sujeitos, a população mostra-se incompreensiva e até mesmo agressiva com os trabalhadores, desencadeando sentimentos, que podem levar ao estresse profissional destes indivíduos.

Assim, a formação dos profissionais desvinculada da realidade das condições de vida e de saúde da população, a falta de preparo da equipe em se adaptar a diferentes realidades, bem como, para o trabalho em equipe, e o desconhecimento da população sobre o objetivo deste novo modelo de assistência causam dificuldades nas relações que deveriam se estabelecer entre os trabalhadores e entre eles e os usuários do serviço.

Espera-se que os integrantes das equipes sejam capazes de conhecer e analisar o seu trabalho, verificando as atribuições específicas e do grupo, na unidade, no domicílio e na comunidade, como também compartilhar conhecimentos e informações (BRASIL, 2001). 
O investimento na capacitação do conjunto da equipe pode propiciar um maior equilíbrio entre os diferentes sujeitos, constituindo-se um elemento facilitador na construção de um projeto comum (SILVA;TRAD, 2005).

Observa-se que alguns profissionais das Equipes de Saúde da Família esforçam-se para a construção de um projeto comum, mas a falta de preparo tem se revelado um entrave neste processo.

O sucesso de uma organização depende de algo mais do que a performance individual. Também depende da qualidade de interação entre os indivíduos, até que ponto eles trabalham juntos dentro de uma equipe e se comunicam efetivamente com outras equipes (WARREN;TOLL, 1998).

A estratégia do PSF como eixo reorganizador da atenção básica trouxe à tona problemas relacionados aos recursos humanos.

No campo da administração dos recursos humanos, aspecto este relacionado ao conteúdo do trabalho, os principais problemas estão relacionados à inadequação de composição das equipes frente às demandas sociais e demográficas, a inexistência de um sistema de informação de recursos humanos que subsidie a definição de diretrizes e implantação de políticas e a inexistência de plano de carreira para trabalhadores (CAMELO et al., 2000).

O estudo revelou que o volume de atendimento e o número de atividades são desproporcionais ao número de profissionais disponíveis e habilitados, favorecendo uma série de riscos psicossociais no ambiente de trabalho como acúmulo de tarefas, ritmo intenso de trabalho, conflito interpessoal no trabalho e com a família, e dessa forma, interferindo significativamente na dinâmica do trabalho e revelando-se como desgastante para os profissionais que nele atuam. Além disso, não existe um plano de carreiras para os profissionais, aumentando o índice de insatisfação frente às dificuldades encontradas.

Esses problemas servem de entrave para a construção de um projeto assistencial. Recursos humanos suficientes no PSF devem ser considerados peças essenciais para que seus objetivos se concretizem. Nos recursos humanos está uma possível solução das maiores questões da saúde. São eles que, sendo capazes de interferir positivamente na modificação das condições de vida e saúde da população e na expectativa de uma sociedade saudável, influirão diretamente na atenção à saúde e na terapêutica prestadas aos indivíduos e coletividades. A saúde exige profissional ético e responsável, na medida em que este passe a reconhecer 
no usuário dos serviços um ser repleto de necessidades complexas e nem sempre objetivadas em uma doença.

Um outro aspecto importante revelado em nossa pesquisa, relacionado ao conteúdo do trabalho, diz respeito aos recursos materiais insuficientes. A escassez de material com a qual se trabalha nas unidades é considerada pelo trabalhador como um fator de desgaste físico e mental. Além desta precariedade, é citada a falta de controle dos mesmos.

O trabalhador de nossa pesquisa expressa preocupação e insegurança com a falta de disponibilização de recursos na unidade. De acordo com Cox et al. (2000), problemas considerando a disponibilidade, conveniência e manutenção de materiais são riscos psicossociais causadores de estresse no trabalhador.

Os profissionais de nosso estudo consideram que os recursos humanos, bem como, os materiais têm papel fundamental na prestação da assistência com qualidade.

Observa-se ainda que, apesar da escassez de recursos humanos e materiais, os trabalhadores procuram descobrir novas formas de enfrentamento das situações adversas. Dizem-se "heróis" pelo que fazem e relatam a necessidade de mudanças nas condições de trabalho, especialmente na sua organização, para que possam oferecer melhor assistência à população, visando a melhora na qualidade de vida dos usuários.

Os resultados apresentados confirmam o nosso pressuposto, de que, há presença de riscos psicossociais no trabalho das Equipes de Saúde da Famíla e mediante o seu aparecimento, estes trabalhadores vão enfrentando e aprendendo no seu cotidiano.

O referencial teórico analítico, inclui nos riscos psicossociais o desenvolvimento na carreira, planejamento das tarefas e decisão e controle, os quais não foram citados por nossos entrevistados. Novos estudos deverão ser realizados buscando entender se estes aspectos estão fora das espectativas destes trabalhadores.

Em termos da presença de riscos ocupacionais, o gerenciamento destes envolve as decisões e ações que ocorrem em dois níveis principais: 1) dentro da sociedade e pelos governos, através de políticas públicas, exigências legais, normas e padrões, que fundamentam a aceitabilidade de determinado risco e as práticas nos locais de trabalho; 2) no interior das empresas, através das práticas 
gerenciais que podem ajudar a prevenir os riscos nos locais de trabalho (PORTO, 2000).

Existem medidas para o controle dos riscos no ambiente de trabalho que podem ser realizadas pelo trabalhador, independente da instituição, quais sejam: exercícios físicos, mudanças no estilo de vida, alimentação equilibrada, entre outras (LIPP, 1996).

O gerenciamento de riscos leva em consideração, além dos aspectos socioeconômicos, aspectos como a viabilidade tecnológica e a gestão adequada de recursos humanos frente às exigências de saúde e segurança, incorporando as melhores tecnologias disponíveis para a saúde dos trabalhadores e no meio ambiente (PORTO, 2000).

O nosso estudo revela estratégias individuais utilizadas pelos profissionais para aliviar os efeitos das situações desgastantes às quais estão expostos, tais como: exercício físico, cinema, ouvir música, a religião e o hábito da leitura.

O exercício físico foi a estratégia mais abordada pelos trabalhadores de nossa pesquisa, 45\% dos sujeitos da pesquisa. Segundo Weinberg e Gould (2001), as pesquisas apontam que indivíduos fisicamente ativos tendem a ter melhor saúde, demonstram energia, têm atitudes mais positivas em relação ao trabalho e revelam uma maior capacidade de lidar com o estresse e com a tensão.

A religião também foi muito citada pelos auxiliares de enfermagem e agentes comunitários de saúde como estratégias para aliviar as tensões do trabalho. Ela deve propocionar a paz interior e ser o abrigo para o amparo espiritual de que as pessoas necessitam.

Uma das funções das crenças religiosas pode ser a de alterarem a atividade do sistema imunológico, prevenindo dessa forma o estresse. Assim, pessoas religiosas teriam mais resistência aos fatores estressores do dia-a-dia, ou seja, melhor adaptação psicológica a elas (RENNÓ JR, 2005).

A religião pode melhorar a saúde promovendo práticas saudáveis de vida, melhorando o suporte social, oferecendo conforto em situações de estresse e sofrimento e até alterando substâncias químicas cerebrais que regulam o humor e a ansiedade. Portanto, ela parece ser um fator psicossocial benéfico na recuperação das doenças físicas e mentais (RENNÓ JR, 2005).

Os trabalhadores consideram importante a utilização destas estratégias para a busca do seu bem-estar físico e emocional e revelam o quanto o volume de 
trabalho e a carga horária, ou seja, as longas horas de trabalho interferem no tempo dedicado a si próprio.

A instituição tem um papel fundamental no desenvolvimento de estratégias para o gerenciamento dos riscos do ambiente de trabalho.

Observa-se em nossa pesquisa uma estratégia realizada pelo serviço, comum a todas as equipes, que são as reuniões semanais, onde há participação de todos os profissionais, com exposição das situações problemas e/ou necessidades da população, bem como, soluções para o cotidiano de seu trabalho. Segundo a população estudada, esta atividade é um momento de "desabafo", onde todos colocam suas idéias, sem medo ou constrangimento. As reuniões são realizadas em dia da semana predefinido pela equipe ou gerente da unidade, mas existe a possibilidade de marcar encontros em outros períodos, de acordo com a necessidade.

Outras estratégias podem ser utilizadas pelo serviço como: programas específicos para a promoção da saúde no local de trabalho, suporte social e emocional e supervisão externa.

A título de reflexão sobre as ações que promovam satisfação no trabalho e saúde dos trabalhadores, sugerem-se diretrizes e mudanças na concepção e organização direcionadas para os aspectos psicossociais no trabalho. Estas diretrizes compreendem, entre outras: prévia conceituação, discussão e consolidação coletivas, em cada organização, sobre as prioridades e conteúdo das mudanças; reformulação nas formas de reconhecimento e valorização dos trabalhadores e de suas funções; mudanças que aumentem a autonomia e controle exercidos pelos trabalhadores sobre seu trabalho sem geração de sobrecarga; enriquecimento do trabalho, e não apenas das tarefas, mediante capacitação profissional, planejada e reconhecida pelos trabalhadores; possibilidades de desenvolvimento na carreira e de estabilidade no emprego; implemento dos níveis de suporte social; melhorias coletivas no fluxo, suportes e qualidade das informações operacionais e organizacionais e melhorias nas condições do ambiente físico de trabalho (MARTINEZ; PARAGUAY; LATORRE, 2004).

Quaisquer dessas abordagens devem contribuir para o equilíbrio do trabalho e conseqüentemente promover uma assistência de qualidade à população. 
7 CONSIDERAÇÕES FINAIS 
O Programa de Saúde da Família é uma das estratégias recentes assumidas pelo Ministério da Saúde com vista à reorganização da atenção básica à saúde.

Para a execução desta prática de assistência, é necessária a estruturação de equipes multiprofissionais que correspondam às necessidades da população e que atuem levando em conta as dimensões sociais, econômicas e biológicas da clientela.

Os profissionais destas equipes assumem múltiplas tarefas com alto grau de exigência e de responsabilidades, para as quais, dependendo do ambiente da organização e planejamento do trabalho, da formação e preparo destes profissionais para exercer seu papel, expõem a riscos psicossociais que podem levar ao estresse.

Nesta pesquisa, analisando o trabalho de Equipes de Saúde da Família, identificamos riscos psicossociais no trabalho que podem levar ao estresse e estratégias de gerenciamento utilizadas pelos trabalhadores.

No desenvolvimento do estudo, utilizamos uma abordagem qualitativa que mostrou ser adequada por ter revelado nos discursos dos trabalhadores sua vivência no cotidiano do trabalho.

Constatou-se a existência de riscos psicossociais como: falta de preparo e capacitação, sobrecarga de papéis, longas horas de trabalho, conflito no trabalho em equipe, dificuldade para conciliar trabalho e família, recursos materiais e humanos insuficientes.

Verificamos que os riscos psicossociais identificados pelos profissionais são fatores que dificultam as atividades preconizadas pelo Ministério da Saúde, pois através de suas percepções e experiências, podem influenciar a saúde dos trabalhadores, o desempenho e a satisfação no trabalho.

As estratégias utilizadas para o alívio destes riscos são predominantemente individuais, sendo que os serviços contribuem com uma reunião semanal em equipe para discussão dos problemas e sugestões.

Os resultados deste estudo, parte de um assunto complexo como o planejamento, a organização e o gerenciamento do trabalho, e a reação do profissional frente às tarefas executadas, exigem aprofundamento, uma vez que, a permanência dos riscos, nas condições de trabalho, traz conseqüências para o trabalhador e serviço. 
Novos estudos devem ser conduzidos no sentido de:

- Identificar riscos físicos, biológicos, ergonômicos nas condições de trabalho;

- Elaborar e implantar um programa de gerenciamento para as situações estressantes no ambiente de trabalho; e

- Elaborar um programa de co-responsabilidade com a comunidade, visando a sua participação no diagnóstico e intervenções para a melhoria da qualidade de vida.

No entendimento de que a realidade sanitária é dinâmica, emergem deste estudo algumas sugestões que podem nortear a estruturação de Equipes de Saúde da Família:

- A qualificação para atuar neste novo campo é fundamental, portanto, ela deve ser iniciada nos programas de graduação e ter uma continuidade em serviço. Faz-se necessária uma reflexão do papel das escolas formadoras junto aos futuros profissionais, a fim de prepará-los para atender às múltiplas exigências da realidade sanitária na qual está inserido;

-As Equipes de Saúde da Família devem ser estruturadas em um ambiente físico adequado e específico para atender à população adscrita no PSF. Os recursos físicos e materiais representam um componente importante na organização do trabalho e sua escassez dificulta as relações que se estabelecem entre trabalhadores e usuários;

-A disponibilização de recursos humanos torna-se imprescindível. Os serviços devem considerar que estes recursos possibilitam a prestação da assistência integral e com qualidade ao indivíduo;

- Um serviço de apoio aos profissionais deve, entre outras atividades, responder às necessidades individuais, orientando os trabalhadores sobre os riscos a que estão expostos, oferecendo suporte social e psicológico, regular encontros com profissionais habilitados, prover oportunidade para comunicar-se com outras equipes que têm experiência similar, promover e dar suporte para pesquisa. Programas específicos devem ser criados para cada situação. 
REFERÊNCIAS 
ALMEIDA, M.C.P; MISHIMA, S.M. O desafio do trabalho em equipe na atenção à Saúde da Família: construindo "novas autonomias" no trabalho. Debates. Rev.Interface-Comunic, Saúde, Educ, São Paulo, n.9, p.150-3, 2001.

ALVES. J.G.; MELLO FILHO. J.; CORDEIRO,H. Stress. JBM, Rio de Janeiro, v.62,n.4, p.39-47, abril, 1992.

BARSTOW, J. Stress variance in hospice nursing. Nursing Outlook, Washington, n.28, p.751-4, 1980.

BAILEY, R.D. Caring for the caregivers. In:

Boston: Chapman and Hall, 1985. Cap.6, p.138-150.

BARDIN, L. Análise de conteúdo. Lisboa: Edições 70, 1977.

BORGES, L.O.;ARGOLO,J.C.T; PEREIRA, A.L.S; Machado, E.A.P.; SILVA, W.S. A síndrome de Burnout e os valores organizacionais: Um Estudo Comparativo em Hospitais Universitários. Psicologia: Reflexão e Crítica. Porto Alegre,v.15, n.1. , 2002.

BRASIL. Ministério da Saúde. Secretaria Nacional de Ações Básicas de Saúde. Divisão Nacional de Organização de Serviços de Saúde. Guia de Supervisão em estabelecimentos de saúde. Brasília, Centro de documentação, 1983.

BRASIL. Ministério da Saúde. Programa de Saúde da Família, Brasília, COSAC, 1994.

BRASIL. $8^{a}$ Conferência Nacional de Saúde- Relatório final. In: MINAYO, M.C.S (org). A saúde em estado de choque. Rio de Janeiro: Fase, 1996, p.117-128. (a)

BRASIL. Ministério da Saúde. Saúde da Família: uma estratégia para a reorientação do modelo assistencial. $2^{\mathrm{a}}$ ed. Brasília: Ministério da Saúde, 1998.

Implantação da Unidade de Saúde da Família. Milton

Menezes da Costa Neto (org). Brasília: Ministério da Saúde. Secretaria de Políticas de Saúde, Departamento de atenção básica, cad.1, 2000, 44p.

BRASIL.Ministério da Saúde. Departamento de Atenção Básica. Guia Prático do Programa de Saúde da Família. Brasília:Ministério da Saúde, 2001.

BRASIL. Ministério da Saúde. Avaliação da Implementação do Programa de Saúde da Família em dez centros urbanos. Síntese dos principais resultados. Ministério da Saúde. Secretaria de Políticas de Saúde. Departamento de Atenção Básica. Sarah Escorel (coordenadora). Brasília: Ministério da Saúde, 2002.

BRASIL. Ministério da Saúde.Organização Pan-Americana da Saúde. Políticas de Recursos Humanos em Saúde. Seminário Internacional. Brasília: Ministério da Saúde, 2002a. 
BRASIL.Conselho Nacional de Educação. Resolução $n^{\circ}$ 4, de 07 de novembro de 2001.Disponível em:< http://www.redeunida.org.br/diretrizes/medicina.asp > Acesso em: 26 jun. 2003.

BRASIL. Ministério da Saúde. Programa Nacional de Reorientação Profissional em Saúde- PRO SAÚDE. Disponível em < http:// portal.saude.gov.br/portal/sgtes/ visualizar_texto.cfm?idtxt=22848 >. Acesso em: 07 abril de 2006.

BRITO, J.S. Procurando compreender os conceitos de carga, trabalho e risco (tecnológico). Revista Brasileira de Saúde Ocupacional,n.72,v.1, janeiro/março,1991.

BOGDAN, R.C.; BIKLEN, S.K. Investigação qualitativa em educação. Porto:Porto Editora, $1999.335 \mathrm{p}$.

BORGES, L.O. ARGOLO,J.C.T; PEREIRA, A.L.S; MACHADO,E.A.P; SILVA, W.S. A Síndrome de Burnout e os valores organizacionais: um estudo comparativo em hospitaos universitários. Psicologia: reflexão e crítica. Porto Alegre. V.15, n.1, 2002.

CÂMARA MUNICIPAL DE RIBEIRÃO PRETO. Lei no 7229 de 24 de outubro de 1995. Autoriza o Executivo a implantar o Programa de Saúde da Família- Médico da Família. Prefeitura Municipal de Ribeirão Preto, SP, 07 nov.1995. Disponível em http://www.camararibeiraopreto.sp.gov.br/camara/leis/1995/-94k.Acesso em 27 jan.2005

CÂMARA MUNICIPAL DE RIBEIRÃO PRETO. Lei no 8350 de 26 de março de 1999. Dá nova redação ao Artigo $2^{\circ}$ da lei n7229/95 (implanta o Programa de Saúde da Família- Médico da Família). Prefeitura Municipal de Ribeirão Preto, SP, 05 ab.1999. Disponível em: <http://www.camararibeiraopreto.sp.gov.br/camara/leis/1995/-94k> . Acesso em 27 jan.2005.

CAMELO, S.H.H.; ANGERAMI,E.L.S.;SILVA, E.M.; MISHIMA,S.M. Acolhimento à clientela: estudo em unidades básicas de saúde no município de Ribeirão Preto. Rev.Latino-am enfermagem. Ribeirão Preto, v.8, n.4,p. 30-37, agosto 2000.

CAMELO, S.H.H.; ANGERAMI, E.L.S. Sintomas de estresse nos trabalhadores atuantes em cinco núcleos de saúde da família. Rev.Latino-am enfermagem, Ribeirão Preto, v.12, n.1, p.14-21, janeiro-fevereiro 2004.

CAMPOS, G.W.S. Reforma da reforma: repensando a saúde. São Paulo, Editora Hucitec, 1992,p149.

CARDIONEWS. Estresse no trabalho e mortalidade cardiovascular.Disponível em: < http:// www.cardionews.org/jornal/2202/ volume_50/volume_50_09.htm>. Acesso em 10 agost. 2005.

CIAMPONE, M.H.T.; PEDUZZI,M. Trabalho em equipe e trabalho em grupo no Programa de Saúde da Família. Rev. Bras. Enferm, v.53, n. esp., p143-7, 2000.

CHIAVENATO, I. Recursos Humanos. 3aed. São Paulo: Atlas, 1995. 
CIDS. Centro de Informação digital em Saúde. Caracterização dos profissionais das equipes de saúde da família [mensagem pessoal]. Mensagem recebida por jscamelo@uol.com.br_em 22 de out. 2004.

CODO, W; SAMPAIO, J; HITOMI, A. Sofrimento Psíquico nas organizações: saúde mental e trabalho. Petrópolis: Vozes, 1995.

COEHLO G.W.; HAMBURG, D.A; ADAMS, J.E. Coping and adaptation: New York: Basic books, 1974.

COOPER, C.L. Executive families under stress. New Jersey: Englewood Cliffs,1981.

COOPER, C.L. Identifying workplace stress: costs, benefits and the way forward. In: European Conference on stress at work- a call for actions,1993, Brussels. Proceeding... Brussels, 1993.

CORNETA,V.K. et al. A reorganização dos serviços de saúde no sistema único de Saúde e a formação de recursos humanos. Saúde em Debate, Londrina, n.51, p.4449, jun.1996.

COSTA, A.L.S. Análise do Stress nas situações de vida diária e do préoperatório imediato de pacientes cirúrgicos urológicos. 1997. 154p. Dissertação (Mestrado)Escola de Enfermagem, Universidade de São Paulo, São Paulo, 1997.

COX, T. The nature and measurement of stress. Ergonomics, Nottingham, v.28 n.8, p.1155- 1163, 1985.

COX, T.;GRIFFITHS,A.J.;RIAL-GONZALEZ,E. Research on work-related Stress. Report to the European Agency for Safety and Health at Work.Luxembourg.2000. Disponível em:http://agency.osha.eu.int/publications/reports /stress. Acesso em janeiro de 2005.

COX, T.; LEATHER, P.; COZ, S. Stress, heakth and organizations. Occupational Health Review, London, n.23, p.13-8, 1990.

COX, T.; HOWARTH, I. Organizational health, culture and helping. Work \& Stress, Nottingham, n 4, p.107-110, 1990

COX, T.; KUK, G. Healthiness of schools as organizations: teacher stress and health. Paper to: International Congress.Stress, Anxiety \& emotional disorders.Braga, 1991.

COX, T.; LEITER, M. The health of healthcare organizations.Work \& Stress, Nottingham, n.6, p.219-227, 1992

COX, T; GRIFFITITHS, A.J. The assessment of psychosocial hazards at work. In: SHABRACQ, M.J; WINNUSBT, J.A.M; COOPER, C.L. (Eds). Handbook of work and Health Psychology. Chichester: Wiley \& Sons, (1995) 
COX, T.; GRIFFITHS, A.J.; BARLOW, C.A.; RANDALL, R.J.; THOMSON, L.E.;RIALGONZÁLEZ, E.. Organizational interventions for work stress: a risk management approach. Sudbury: HSE books, 2000.

COX, T. RIAL-GONZÁLEZ, E. Work-related stress: The european picture. In: Working on stress. Magazine of the European Agency for Safety and Health at work Luxembourg: European Communities, 2002.n.5, p.4,

CRUZ NETO, O. O trabalho de campo como descoberta e criação. In: MINAYO, M.C.S. (Org). Pesquisa social: teoria, método e criatividade, 18. ed. Rio de Janeiro: Vozes, 1994. p.51-66.

DEJOURS, C. A loucura do trabalho. Estudo de psicopatologia do trabalho. $5^{\mathrm{a}}$ ed. São Paulo: Cortez-Oboré.1992. 168p.

DIAMANTOPOULOU, A. Europe under stress. In: Working on stress. Magazine of the European Agency for Safety and Health at work. Luxembourg: European Communities, 2002.n.5, p.3

EUROPEAN AGENCY FOR SAFETY AND HEALTH OF WORK,2000, Bilbao. Research on work-related stress. Bilbao: European Agency, 2000.

EUROPEAN COMMISSION,1996, Brussels. Guidance on risk assessmente at work. , Brussels: European Commission, 1996.

EUROPEAN COMMISSION,2000, Luxembourg. Guidance on work-related stressSpice of life or kiss of death? Luxembourg: European Communitites, 2000.

EUROPEAN FOUNDATION, 1996, Ireland. Second European Survey on working conditions in the European Union, Ireland: Dublin, 1996.

FERREIRA, M.C. Trabalhar em ambiente feliz: é possível? Universidade de Brasília. Disponível em: < http:// www.unb.br/acs/bcopautas/saude19.htm>. Acesso em: 17 set. 2005.

FINK, S.V. The influence of family resources and family demands on the strain and well-being of caregiving families. Nursing Research, New York, v.44, p.139-145, 1995.

FORNÉS, J. Respuesta emocionalal strés laboral. Rol de enfermería. 1994: 186:31- 39.

FRANÇA, A.C.L; RODRIGUES, A.L. Stress e trabalho - uma abordagem psicossomática. São Paulo: Atlas, 1999. 154p.

FREDERICKSEN, C.H. Stress a common disease? In: Working on stress. Magazine of the European Agency for Safety and Health at work. Luxembourg: European Communities, n.5, 2002 ,p.5-6 
FRENCH, J.R.P; CAPLAN, R.D. Psychosocial factors in coronary heart disease.Journal Industrial Medicine, New York, n.39, p.383-397, 1970.

GARDELL, B. Quality of work and non-work activities and rewards in affluent societies. Reports from psychological laboratories n.403, University of Stockholm, Stockholm. 1973.

GIL, A.C. Como elaborar projetos de pesquisa, 2a ed., São Paulo, Atlas, 1989, cap.4, p. 45-62.

GIRDANO, D.A.; EVERLY, G.S. Controlling stress and tension: a holistic approach. New Jersey: Prentice Hall, 1979.

GREENBERG, J.S. Administração do estresse. 6ª ed., São Paulo: Manole, 2002.

GUIMARÃES, S.S. Valores e princípios: aprendi assim. In: LIPP, M.N. (Ed). O stress está dentro de você . São Paulo: Contexto, 1999, p.63-74.

HACKER, W. Objetive work enviroment: analysis and evaluation of objetive work characteristics. Paper presented to: a Healthier work Enviroment: Basic Concepts \& Méthods of measurement. Stockholm, 1991.

HEALTH,Inc.Stress at work. Disponível em: < http:// www. athealth.com/consumer/ disorders/workstress.html > acesso em 16 de abril de 2004.

HINGLEY, P.; COOPER, C.L. Stress and the nurse manager. Chichester: Wiley \& Son, 1986.

HOLT, R.R. Occupational Stress. In: GOLDBERGER, L \& BREZNITZ, S. ( Ed.) Handbook of stress. Theoretical and Clinical Aspects. New York: Free Press, 1982, v.2,cap.25, p419-444.

[ILO] INTERNATIONAL LABOUR OFFICE. Psychosocial factors at work: recognition and control. Report of the joint . ILO/WHO. Committee on Occupational Health- Ninth Seesion. Geneva, 1984.

INGERSOLL G.L.; COOK J.A.; FOGEL S.; APPLEGATE M.; FRANK, B. The effect of patient-focused redesign on midlevel nurse manager's role responsibilities and work environment. Journal of Nursing Administration, Hagerstown, v. 29,n.5, p217, 1999.

IVANCEVICH, J.M; MATTESON, M.T. FREDDMAN, S.M.; PHILIPPS, J.S.Worksite stress management interventions. American Psycologist, Washington, n.45, p. 252261, 1990.

JACQUES, M.G.C. Identidade e trabalho: uma articulação indispensável.In:TAMOIO, A; BORGES, J.; CODO, W. (orgs). Trabalho, Organizações e Cultura. São Paulo: Autores Associados, p21-26, 1996. 
JENKINS, R.; CONEY, N. Preventions of Mental ill health at work. London:HMSO, 1992

JEX, S.M. Stress and job performance. Londres:Sage, 1998.

JONES, D.M. Noise. In: HOCKEY G.R.J. Stress and fatigue in human performance. Chichester: Wiley \& Sons,1983.

JONES, J.W..; BARGE, B.N.; STEFFY, B.D.; FAY, L.M.; KUNZ, L.K.; WUEBKER, L.J. Stress and medical malpractice: organizational risk assesment and intervention. Journal of Applied Psychology, Washington, n.73, p.727-735, 1988.

JUNQUEIRA, L.A.P. Gerência dos serviços de saúde. Cadernos de Saúde Pública. Rio de Janeiro, v.6, n.3,p.247-259, 1990.

KAHN, R.L.; WOLFE, D.M.; QUINN, R.P.; SNOEK, J.D.; ROSENTHAL, R.A. Organizational stress: studies in role conflict and ambiguity. New York: Wiley \& Sons, 1964.

KANAANE, R. Comportamento humano nas organizações: o homem rumo ao Século XXI. São Paulo: Atlas, 1994.

KASL, S.V. Assessing health risk in the work setting. In: SCHROEDER, H.E. (Ed.):New directions in heakth psychology assessment. New York: Hemisphere Publishing, 1991, p. 95-125.

KASL, S.V. Surveillance of psychological disorders in the workplace. In: KEITA,G.P.; SAUTER, S.L. (Eds). Work and well-being: An agenda for the 1990s.American Psycological Association, Washington DC. 1992.

KEITA, G.P; SAUTER, S.L. (Ed). Work and well-being: an agenda for the 1990s. American Psychological Association, Washington DC, 1992.

KORNHAUSER, A. Mental health of the industrial worker.University of Chicago Press, Chicago: Illinois, 1965.

KUHN, K. Managing stress by promoting health. In: Working on stress. Magazine of the European Agency for Safety and Health at work. Luxembourg, n.5, p23-4, 2002.

KURCGANT, P; CUNHA, K.C; MASSAROLLO, M.C.K.B; CIAMPONE, M.H.T; SILVA, V.E.F; CASTILHO, V; LEITE, M.M.J; GAIDZINSKI, R.R; PEREIRA,L.L; TAKAHASHI,R.T. Administração em Enfermagem. São Paulo:EPU, 1991.237p.

LAKATOS, E.M; MARCONI, M.A. Fundamentos de metodologia científica. São Paulo, Atlas, 1985.240p.

LANDY, F.J .The Psycology of work behaviour. Monterey, California:Brooks/Cole,1989. 
LARWOOD, L.; WOOD, M.M. Women in management., London : Lexington Books, 1979.

LAZARUS, R.S.; FOLKMAN, S. O processo de coping: uma alternativa a formulações tradicionais. In:

York: Springer, 1984. Cap.6, p.141-180.

Stress, appraisal and coping. New

LEATHER, P; BRADY, C; LAWRENCE, C; BEALE, D; COX T. (Ed) Work- related violence: Assesmente and intervention. London: Routledge, 1999.

LEITER, M. The dream deneid: professional burnout and the constraint of human service organizations. Canadian Psychology, Canadian, n.32, p.547-558, 1991.

LIMA, D.R. Manual de farmacologia clínica, terapêutica e Toxicologia. Rio de Janeiro: Guanabara Koogan, 1994.

LIMA, E.D.R.P.; CARVALHO, D.V. Estresse ocupacional, Nursing, São Paulo,n. 2, p. 30-34, 2000.

LINDA, E.R. Caring for caregivers: perceptions of social suport. Journal of Psychosocial Nursing, New Jersey, v.35, n.2, p.17-24, 1997.

LIPP, M.E.N. Stress e suas implicações. Estudos de Psicologia. Campinas, v.1,p.3-9, 1984.

LIPP, M.E.N. Stress: conceitos básicos. In: LIPP, M.E.N.(Ed.) Pesquisas sobre stress no Brasil: Sáude, ocupações e grupos de risco. Campinas: Papirus, 1996.Cap.1, p.17-31.

LIPP, M.E.N.; MALAGRIS, L.N.O stress emocional e seu tratamento. In: RANGE, B. (Ed.) Psicoterapias Cognitivo-comportamentais. Campinas:Psy II Campinas, 2001. p.475-90.

LIPP, M.E.N. Mecanismos neuropsicofisiológicos do stress: teoria e aplicações clínicas. São Paulo: Casa do Psicólogo, 2003.

LOCKE, E.A. Job satisfaction. In: GRUNEBERG, M; WALL, T. (Editors). Handbook of industrial and organizational psychology. Chicago: Rand McNally;1976. p.1297-349.

LUDKE, M; ANDRÉ, E.D.A. Pesquisa em educação: abordagens qualitativas. São Paulo: EPU, 1986.

LUNDAHL, A. Fritid Och rekreation. All Manna Forlager. Stockholm 1971.

MACEDO, E.I.N. Transtornos Psiquiátrico e Produtividade no trabalho. São Paulo. Disponível em htp/l: www.prolavore.com.br/pdf/trans_prod_trabalho.pdf Acesso em 17/09/2005. 
MAIA, S.C. Análise ergonômica do trabalho do enfermeiro em uma Unidade de Terapia Intensiva: proposta para a minimização do estresse e melhoria da qualidade de vida do trabalhador.1999. 178p. Dissertação [Mestrado]. Programa de Pós-graduação em engenharia de produção, Universidade de Santa Catarina, Florianópolis, 1999.

MALASCH, C.Stress, burnou and workaholism. In: KILBURG, R.; NATHAN, P.E; THORESON, R.W (Orgs.) Professionals in distress: issues, syndromes and solutions in psychology. Washington. American Psychological Association, p.5355, 1994.

MARGOLIS, B.; KROES, W.H.; QUINN, R.P. Job stress; an unlisted occupational hazard. Journal of Occupational Medicine, Washington, n.16, p.652-661, 1974.

MARSHALL, J. Job pressures and satisfactions at managerial levels.Unpublished PhD thesis, University of Manchester. Institute of Science and technology, Manchester, 1977.

MARTINEZ,M.C.PARAGUAY,A.I.B.B.;LATORRE, M.R.D.O. Relação entre satisfação com aspectos psicossociais e saúde dos trabalhadores. Rev. Saúde Pública. São Paulo. 38 (1):55-61,fevereiro, 2004.

MACHADO, M.H. Perfil dos médicos e enfermeiros do Programa de Saúde da Família no Brasil: relatório final. Brasília: Ministério da Saúde, 2000.

MAZON, L; TREVIZAN, M.A.. Recrutamento e Seleção de Recursos Humanos em um Hospital Psiquiátrico de um município paulista. Revista Latino-am enfermagem. Ribeirão Preto. 8( 4): 81-7, agosto, 2000.

MEIRELLES, B.H.S. A enfermagem frente aos riscos do ambiente hospitalar.Cogitare Enfermagem. Paraná. 1997. 2 (1):21-24.

MENDES, E.V. Distrito Sanitário: o processo social de mudança das práticas sanitárias do Sistema Único de Saúde. São Paulo: Hucitec, 1995.

MENDES, E. V. Uma agenda para a saúde. São Paulo: Hucitec, 1996. 300p.

MENEZES, L.C. Seu trabalho pode afetar a família. Revendo. Disponível em: http://members.tripod.com.br/ Icsm/revendo_numero44.htm Acesso em: 8 de agosto de 2005.

MISOCZKY, M.C. A medicina da família, os ouvidos do príncipe e os compromissos com o SUS. Saúde em Debate ,1994;(42): 40-4.

MINAYO, M.C.S. Ciências, técnica e arte: o desafio da pesquisa social. In: MINAYO, M.C.S. (Org). Pesquisa social : teoria, método e criatividade. 18. ed. Rio de Janeiro: Vozes, 1994. p.9-29. 
MISHIMA, S.M. A gerência de Serviços de Atenção primária à saúde como instrumento para a organização da assistência à saúde- o caso do Programa de Saúde da Família. [tese] Ribeirão Preto, 2003.

MOLINA, O.F. Estresse no cotidiano. São Paulo: Pancast, 1996.

MORAIS, P. C. et al. Incidência de stress em profissionais da área de saúde. In:I Congresso Norte-nordeste de Psicologia. Va semana Baiana de Psicologia, 1999. Salvador.Anais... Salvador: Universidade Federal da Bahia. Disponível em: < http://www.ufba.br/ncompsi/compsi1999/p086.html > acesso em : 02 de fev. 2002.

MORENO-JIMENEZ, B.; PEÑACOBA-PUENTE, C. Prevención y control del estrés laboral. Ansiedad y Estrés. 1(2-3): 255-264, 1995.

MURPHY, L.R. Occupational stress management: a review and appraisal. Journal of Occupational Psychology, London, n. 57, p.1-15, 1984.

MURPHY, L.R. Stress management in work settings: A critical review of the health effects. American Journal of Health Promotion. 11(2), 112-135, 1996.

NACARATO, A.E.C.B. Envelhecer é isto... In: LIPP, M.N. (Ed.) O stress está dentro de você. São Paulo: Contexto, 1999, p.141-151.

NEGRÃO, C.E.; ANGELO, L.F. A importância do exercício físico no manejo do stress. In: LIPP, M.E.N. Mecanismos neuropsicofisiológidos do stress: teoria e aplicações clínicas. São Paulo: Casa do Psicólogo, 2003.

NEWMAN, J.E.; BEEHR, T.A. Personal and organizational strategies for handling job stress: a review of research and opinion. Personel Psychology, Chicago, n.32,p 143, 1979.

NOGUEIRA, R.P. Resultados do Estudo de Avaliação de Tendências e Prioridades sobre Recursos Humanos em Saúde.In: Brasil. Ministério da Saúde. Política de Recusos Humanos em Saúde. Seminário Internacional. Brasília: Ministério da Saúde, 2002.

OIT- Organización Internacional del Trabajo. Factores psicosociales em el trabajo. Naturaleza, incidencia y prevención. Genebra: OIT, 1984.

PAIM J.M.A. Reforma Sanitária e a municipalização. Saúde e Sociedade, São Paulo, v.1, n.2, p.31,1992.

PAIM, J.S. A reorganização das práticas de saúde em distritos sanitários. In: MENDES, E. V. (org). Distritos Sanitários: o processo social da mudança das práticas sanitárias do Sistema Único de Saúde. São Paulo: Hucitec, Rio de Janeiro: Abrasco, 1993. p.187-220. 
PASCHOAL, t. Relação dos valores do trabalho e da interferência famíliatrabalho com estresse ocupacional. Brasília. Dissertação [Mestrado] Instituto de Psicologia, Universidade de Brasília, 2003.

PEDROSA, J.I.S.; TELES, J.B.M. Consenso e diferenças em equipes do Programa de Saúde da Família. Rev. Saúde Pública, v.35, n.3, p303-311, 2001.

PEIRÓ, J.M. Desencadeantes Del strés laboral. Madrid: Eudema, 1993.

PEDUZZI, M. PALMA, J.J.L. A equipe de saúde. In: MENDES-GONÇALVES, R.B.; NEMES, M.I.B; SCHRAIBER, L.B. ( Orgs) Saúde do adulto: Programas e ações na unidade de saúde. São Paulo: Hucitec, 1996. p234-50.

PEDUZZI, M. Equipe multiprofissional de saúde: conceito e tipologiaatualização.Rev. Saúde Pública, v.1,p.103-9, 2001.

PENNA, C.M.M.; ALVES, M.; BRITO, M.J.M.; ABREU, T.;SOARES, C.E. O trabalho do gerente no cotidiano das Unidades Básicas de Saúde. Revista Mineira Enf.; 8( 4): 455-463, Belo Horizonte. 2004.

PETERSON, M.; DUNNAGAN, T. Analysis of a worksite health promotion program's impacto $n$ job satisfaction. J. Occup Environ Med. 40:973-9, 1998.

PORTER,L.W. Commitment patterns in industrial organizations. Paper to: society for industrial and organizational psychology. Miami Beach, 1990.

PORTO, M.F.S. Análise de riscos nos locais de trabalho: conhecer para transformar. Cadernos de Saúde do Trabalhador. Instituto Nacional de Saúde no Trabalho. São Paulo. 2000. Disponível em: www.instcut.org.br. Acesso em junho de 2005.

RAPHAEL, A.V. I. Stress ocupacional na enfermagem. Ribeirão Preto. (Monografia). Curso de Graduação. Centro Universitário Barão de Mauá. 1999

RENNÓ JR, J. A relação entre religião e medicina. On line. São Paulo, 23 nov. 2005.

Disponível

em:<http://www.diariosp.com.br/colunistas/matéria.asp?Editoria=18\&id_coln= 623\&mês=5> Acesso em: 23 nov. 2005.

RIBEIRÃO PRETO. Prefeitura Municipal de Ribeirão Preto. Características gerais do município, SP. Disponível em: <http://www.ribeiraopreto.sp.gov.br/ssaude/ Vigilância/Planeja//16plano.htm> Acesso em: 15 abr. 2005.

RIBEIRÃO PRETO. Secretaria Municipal de Saúde. Plano de Saúde de Ribeirão Preto. SUS. Período2005-2008.Disponível em <http://www.coderp.com.br/saude/ i16principal.asp?pagina/ssaude/principal/painel//16indice.htm>Acesso em dezembro de $2005 a$.

ROBERSTON IT, COOPER CL. Human behaviour in organizations. London: Macdonald and Evans Ltd, 1983. 
SANTANA, M.L.; CARMAGNANI, M.I. Programa saúde da família no Brasil: um enfoque sobre os pressupostos básicos, operacionalização e vantagens. Saúde Sociedade, São Paulo, v.10, n.1. p.33-53, 2001.

SANTOS, M.A.M; CUTOLO, L.R.A. A interdisciplinaridade e o Trabalho em equipe no Programa de Saúde da Família. Arquivos Catarinenses de Medicina, Santa Catarina, v.32, n.4., p.65-74, 2003.

SARTI, C.A. Os filhos dos trabalhadores: quem cuida das crianças? In: BRETAS, A.C.P Trabalho, saúde e gênero: na era da globalização. Goiânia (GO): AB; p.5160, 1997.

SAUTER SL, HURRELL JJ, COOPER CL. Control and worker health. Chichester: Wiley \& Sons, 1989.

SCHRAIBER, L.B.; PEDUZZI, M.; SALA, A.; NEMES, M.I.B.;CASTANHEIRA,E.R.L; KON, R. Planejamento, gestão e avaliação em saúde: identificando problemas. Rev. Ciênc. Saúde Colet., v.4, n.2, p221-42, 1999.

SEEGERS, C; VAN ELDEREN, T. Examining a model of stress reactions of bank directors. European Journal of Psychological Assessment,v.12, n.3. p. 212223,1994.

SEIXAS, P.H.A. Os pressupostos para a Elaboração da Política de Recursos Humanos nos Sistemas Nacionais de Saúde. In: Brasil. Ministério da Saúde. Política de Recursos Humanos em Saúde. Seminário Internacional. Brasília: Ministério da Saúde, 2002.

SELIGMAN-SILVA, E. Sociabilidade, trabalho e loucura. In: TUNDIS, S.A.; COSTA, N.R. (orgs). Cidadania e loucura: políticas de saúde mental no Brasil. Petrópolis: Ed. Vozes/Abrasco, 1990.

SELYE, H. The stress of life. New York: Mc. Graw Hill, 1956.

SESCSP. Fatores de risco. L.E.R. Disponível em: www.sescpsp.org.br/sesc/ convivência/ler/ 02_1_Fatores.htm. Acesso em agosto de 2005.

SHABRACQ M.J.; WINNUBST, J.A.M; COOPER, C.L. Handbook of work and Health Psycology Chichester. Chichester: Wiley \& Sons, 1995.

SILVA, E.M. Supervisão em enfermagem. Análise crítica das publicações no Brasil dos anos 30 à década de 80. Ribeirão Preto, 1991. 158p. Dissertação (Mestrado)Escola de Enfermagem de Ribeirão Preto, Universidade de São Paulo.

SILVA, F.P.P. Burnout: um desafio à saúde do trabalhador. PSI-Revista de Psicologia Social e Institucional. Universidade Estadual de Londrina, Londrina. 2000. Disponível em: URL:<http://www2.uel.br/ccb/psicologia/revista/textov2n15. htm>. Acesso em:10 set. 2005. 
SILVA, I.Z.Q,J.; TRAD, L.A.B. O trabalho em equipe no PSF: investigando a articulação técnica e a interação entre os profissionais. Interface-Comunicação, Saúde, Educação. v.9., n.16,p 25-38 Sep/Feb. 2005.

SPILBERGER, C. Understanding stress and anxiety. New York: Haper e Row Publishers, 1979.

SMITH, A. A review of the non auditory effects of noise on health. Work \& Stress, Notthinghan, n.5,p. 49-62, 1991.

SPINDOLA, T.; SANTOS,R.S.. Mulher e trabalho- a história de mães trabalhadoras de enfermagem. Revista Latino-am enfermagem, v. 11, n.5, set-out, 2003.

STAMPI, C. Polyphasic sleep strategies improve prolonged sustained performance: a field study on 99 sailors. Work \& Stress, Notthinghan n.3, p.41-55,1989.

STELLA, R.C.R. Desafios e Estratégias para Interiorização do Trabalho em Saúde. In: Brasil. Ministério da Saúde. Política de Recursos Humanos em Saúde. Seminário Internacional. Brasília: Ministério da Saúde, 2002.

STEWART, R. Constrasts in management. New York: Mcgraw-hill, 1976.

TAYLOR, S.E. Health Psicology. In: LAZARUS, R.S.; MONAT, A. (Ed). Stress and coping. $3^{\mathrm{a}}$ ed, New York, 1991, cap.4, p62-80.

TERRY, D.J; JIMMIESON, N.L. Work control and employee well-being: a decade review. In: Cooper, C.L.; Roberston, I.T. (Ed) International review of industrial and organizational psychology. Chichester: American Ethnological Press, 1999, p.95-148.

URBANO, L.A. A privatização da saúde e a implantação do SUS: cenários de um cidade. Ribeirão Preto: FUNPEC, 2003.

VASCONCELLOS, E.G. O modelo psiconeuroendocrinológico do stress. In: Seger, L. Psicologia e Odontologia. 2aed. São Paulo: Santos, 1992. Cap. 2, p25-47.

VASCONCELLOS, E.G. Educação popular e a atenção à saúde da família. São Paulo:Hucitec, 1999.

WAGNER, H.L. Princípios do programa de saúde da família. Curso para profissionais de nível médio da regional de saúde do Pinheirinho, Curitiba, 1996.Disponível em : < http://members-tripod.com.br/nilson/saudedafamilia6.htm >Acesso em : 08 agost. 2000.

WARR, P.B. Job features and excessive stress. In: JEKINS, R; CONEY, R. (eds). Prevention of mental ill health at work. HMSO: London, 1992.

WARSHAW, L.J. Managing stress. Addison-Wesley, Mass. 1979 
WARREN, E; TOLL,C. Como dominar seu stress: como indivíduos equipes e organizações podem equilibrar pressão e performance. Tradução: Tereza Queiroz. Rio de Janeiro: Infobook; 1998.235p.

WEINBERG, A.; CREED, F. Stress and psychiatric disorder in healthcare professional and hospital staff. Lancet. New York, Feb.355(9203): 533-7, 2000.

WEINBERG, R.S. GOULD, D. Fundamento da Psicologia do esporte e do exercício. Porto Alegre. Artmed Editora. 2a ed. 2001.

WYKES,T.; STEVENS, W; EVERITT, B. Stress in community care teams: will it affect the sustainability of community care? Soc.Psychiatr Epidemiol. Berlim, v.32, n.7, p.398-407, 1997.

WYNNE R, CLARKIN N, COX T, GRIFFITHS A.Guidance on the prevention of violence at work. Luxembourg: European commision, 1997.

YIN, R.K. Estudo de caso: planejamento e métodos. $2^{\mathrm{a}}$ ed. Porto Alegre: Bookman, 2001.205p. 

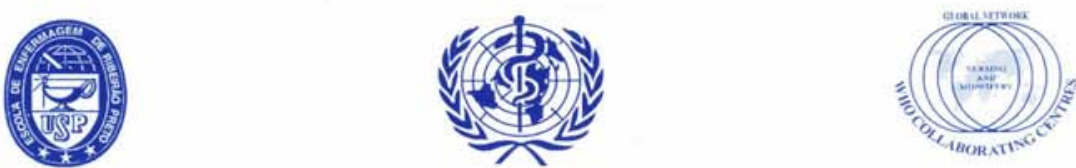

ESCOLA DE ENFERMAGEM DE RIBEIRÃO PRETO - UNIVERSIDADE DE SÃO PAULO

CENTRO COLABORADOR DA ORGANIZAÇÃO MUNDIAL DA SAÚDE PARA O DESENVOLVIMENTO DA PESQUISA EM ENFERMAGEM

COMITÊ DE ÉTICA EM PESQUISA DA EERPIUSP

Of.CEP-EERP/USP - 0157/2004

Ribeirão Preto, 21 de dezembro de 2004

Prezada Senhora,

Comunicamos que o projeto de pesquisa, abaixo especificado, foi analisado e considerado APROVADO AD REFERENDUM do Comitê de Ética em Pesquisa da Escola de Enfermagem de Ribeirão Preto da Universidade de São Paulo, em 21 de dezembro de 2004

Protocolo:

$n^{\circ} 0506 / 2004$

Projeto:

Condiçöes de Trabalho das Equipes de Saúde da Familia: Estudo dos Estressores Psicossociais

Pesquisadores: Emilia Luigi Saporiti Angerami (Orientadora)

Silvia Helena Henriques Camelo (Doutoranda)

Em atendimento à Resolução 196/96, deverá ser encaminhado ao CEP o relatório final da pesquisa e a publicação de seus resultados, para acompanhamento, bem como comunicada qualquer intercorrência ou a sua interrupção.

Atenciosamente,

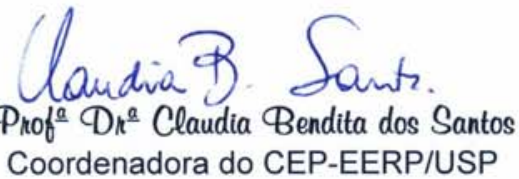

IIma. Sra.

Prof ${ }^{a} r^{a}$ Emilia Luigi Saporiti Angerami (Orientadora)

Departamento de Enfermagem Geral e Especilizada

Escola de Enfermagem de Ribeirão Preto da Universidade de São Paulo 


\section{APÊNDICES}




\section{APÊNDICE I \\ ROTEIRO PARA A REALIZAÇÃO DAS ENTREVISTAS}

\section{DADOS DE IDENTIFICAÇÃO:}

IDADE:_SEXO__ESTADO CIVIL

FUNÇÃO EXERCIDA/OCUPAÇÃO

Q.1. Fale sobre o seu preparo para trabalhar nesta unidade na equipe de saúde da família. (Se fez algum treinamento para exercer esta função, recebeu ou recebe educação em serviço, se há incentivo institucional para aprimoramento)

Q.2 .No desempenho de suas atividades, que condições são oferecidas pelo serviço? Existe alguma dificuldade? ( tarefas, recursos materiais/ humanos)

Q.3. Como você se sente após uma jornada de trabalho? O que você considera desgastante e prejudicial para a sua saúde? ( tarefas - controle e divisão de tarefas, a falta de preparo para lidar com a comunidade; carga horária; relacionamento interpessoal com colegas e comunidade; hierarquia).

Q.4. Como é para você conciliar as atividades e o tempo de dedicação ao trabalho e à sua família? ( $\mathrm{O}$ horário de trabalho adapta-se às suas obrigações sociais e familiares fora do seu traballho, pratica alguma atividade fora do seu trabalho, está satisfeito ou não com o período dispensado à família).

Q.5. Você se utiliza de algum recurso pessoal ou institucional para aliviar os efeitos de situações difíceis que enfrenta no dia-a-dia do seu trabalho.

DATA DA ENTREVISTA: DIA _ MÊS HORA DE INICIO DA ENTREVISTA; DURAÇÃO DA ENTREVISTA: 


\section{APÊNDICE II}

\section{TERMO DE CONSENTIMENTO LIVRE E ESCLARECIDO}

Prezado colega

$\mathrm{Na}$ busca do tema para minha tese de doutorado, detive-me nas condições de trabalho do profissional da equipe de Saúde da Família. Os objetivos da pesquisa são: identificar e analisar, de acordo com a percepção dos trabalhadores das equipes de saúde da família do município de Ribeirão Preto, os riscos psicossociais presentes na organização e no ambiente de trabalho e as estratégias utilizadas pelos trabalhadores que podem estar amenizando as situações estressantes presentes.

Os dados de nossa pesquisa serão coletados através de entrevistas, semiestruturadas, isto é, com um roteiro previamente elaborado.

A entrevista apresentará além de dados de identificação como idade, sexo, estado civil e função exercida no local de trabalho, 13 perguntas abertas relacionadas ao tema proposto. O conteúdo das entrevistas será gravado em fita cassete, posteriormente transcrito e guardado em segurança, estando disponível para os participantes durante e após as entrevistas.

Sua contribuição na pesquisa consiste em participar dessa entrevista, que ocorrerá no ambiente de trabalho, de acordo com a sua disponibilidade. Informo-lhe que, caso concorde em participar, será mantido seu sigilo e anonimato. Além disso, você poderá interromper sua participação a qualquer momento, sem prejuízo de qualquer natureza.

O projeto de pesquisa já foi analisado e avaliado quanto às questões éticas, pela Escola de Enfermagem de Ribeirão Preto- USP.

Assim agradeço antecipadamente sua colaboração e peço que assine o presente, autorizando a reprodução e divulgação dos dados. 
Eu

$\mathrm{RG} \mathrm{n}^{\circ}$ , concordo em participar voluntariamente da pesquisa referida acima, que será desenvolvida pela aluna Silvia Helena Henriques Camelo, pós-graduanda em Enfermagem da Escola de Enfermagem de Ribeirão Preto/USP, sob orientação da Professora Doutora Emília Luigi Saporiti Angerami.

Assinatura do participante

Pesquisador responsável

Silvia Helena Henriques Camelo

Endereço: Rua Maria da Glória Machado Santana, 939. Ribeirão Preto. Telefone: (016) 39170196 